UNIVERSIDADE DE SÃO PAULO

HOSPITAL DE REABILITAÇÃO DE ANOMALIAS CRANIOFACIAIS

FERNANDA PATARO MARSOLA RAZERA

Tomografia Computadorizada: Inclinação e angulação dos dentes anteriores em pacientes com fissura labiopalatina bilateral 

FERNANDA PATARO MARSOLA RAZERA

\title{
Tomografia Computadorizada: Inclinação e angulação dos dentes anteriores em pacientes com fissura labiopalatina bilateral
}

\author{
Dissertação apresentada ao Hospital de \\ Reabilitação de Anomalias Craniofaciais da \\ Universidade de São Paulo para obtenção do título \\ de Mestre em Ciências da Reabilitação. \\ Área de Concentração: Fissuras Orofaciais e \\ Anomalias Relacionadas \\ Orientador: Prof. Dr. Leopoldino Capelozza Filho
}

\section{BAURU}




\section{AUTORIZO A REPRODUÇÃO E DIVULGAÇÃO DESTE TRABALHO, POR QUALQUER MEIO CONVENCIONAL OU ELETRÔNICO, PARA FINS DE ESTUDO E PESQUISA, DESDE QUE CITADA A FONTE.}

\begin{tabular}{|c|c|}
\hline & Razera, Fernanda Pataro Marsola \\
\hline \multirow[t]{4}{*}{$\mathrm{R} 219 \mathrm{t}$} & $\begin{array}{l}\text { Tomografia Computadorizada: Inclinação e angulação } \\
\text { dos dentes anteriores em pacientes com fissura } \\
\text { labiopalatina bilateral./ Fernanda Pataro Marsola Razera. } \\
\text { Bauru, 2010. } \\
\quad \text { 177p.; il.; } 30 \mathrm{~cm} \text {. }\end{array}$ \\
\hline & $\begin{array}{l}\text { Dissertação (Mestrado - Área de Concentração: } \\
\text { Fissuras Orofaciais e Anomalias Relacionadas) - Hospital } \\
\text { de Reabilitação de Anomalias Craniofaciais, Universidade } \\
\text { de São Paulo. }\end{array}$ \\
\hline & Orientador: Prof. Dr. Leopoldino Capelozza Filho \\
\hline & $\begin{array}{l}\text { 1. Tomografia, 2. Ortodontia corretiva, 3. Fissura } \\
\text { labiopalatina. }\end{array}$ \\
\hline
\end{tabular}




\section{FOLHA DE APROVAÇÃO}

Fernanda Pataro Marsola Razera

Dissertação apresentada ao Hospital de Reabilitação de Anomalias Craniofaciais da Universidade de São Paulo para obtenção do titulo de Mestre em Ciências da Reabilitação.

Área de Concentração: Fissuras Orofaciais e Anomalias Relacionadas

Aprovado em:

Banca Examinadora

Prof. Dr.

Instituição Assinatura

Prof. Dr.

Instituição Assinatura

Prof. Dr.

Instituição (Orientador):

Prof.(a) Dr.(a)

Presidente Pós Graduação HRAC

Data do depósito da dissertação junto ao SPG: 



\section{DEDICATÓRIA}

Em primeiro lugar, agradeço a Deus, por todas as graças que tenho recebido em minha vida, por todas as oportunidades que me foram dadas e por todas as pessoas com as quais tive o prazer de conviver.

Aos meus pais, Carlos e Marli Marsola, que sempre me incentivaram a buscar novos conhecimentos e empreender novos desafios. A ajuda e o amor de vocês em todos os momentos foram fundamentais para que eu concluísse o Mestrado. Muito Obrigada, eu os amos muito!

Ao meu marido, Jorge Alberto Razera, muito obrigado por estar sempre ao meu lado, me apoiando em todas as decisões tomadas e pela sua compreensão nos momentos (e não foram poucos) em que eu precisei me concentrar na execução dessa dissertação.

Aos meus irmãos, Daniel e Érika, que durante nossas vidas foram meus companheiros, incentivadores e comemoram junto comigo cada vitoria alcançada. A união de nossa família é um grande alicerce para continuarmos sempre voando mais alto.

Aos meus sogros, Hélio e Maria Ivani Razera, pela fé que vocês demonstram em tudo aquilo que fazem na vida pessoal, em família e na sociedade. Vocês são um grande exemplo a ser seguido e me orgulho muito de fazer parte dessa família também.

Ao meu filho Thiago, uma dedicatória mais que especial. Você chegou ao mundo junto com mestrado. Foi meu companheiro nas aulas (ainda na barriga), não me sentia sozinha, pois você sempre dava o ar da graça se mexendo lá dentro da barriga. Nasceu e como um anjo que é aceitou a ausência de sua mãe, em muitos momentos, para que esse meu objetivo fosse alcançado. Ganhou assim a companhia dos avós que só te paparicam. Você transformou a minha vida e é sem dúvida a razão de meu viver. Te amo muito mais que a mim mesma!!! 

Ao meu outro anjinho que está aqui na minha barriga acompanhando o final do mestrado. Que você nasça com muita saúde. Estou a sua espera e já te amo demais

A minha avó Durvalina. Você é avó, é também minha segunda mãe e se não bastasse, minha madrinha. Só me resta dizer que tem um lugar mais que especial em meu coração. Te amo.

Aos que já partiram deixando muitas saudades: vô Geraldo, vô Fausto, vó Maria e tio Paulo. Exemplos de vida, de sabedoria e de superação que levarei sempre comigo. Estejam sempre em paz.

A todos os meus familiares. Muito obrigada pela união de nossas famílias. 



\section{AGRADECIMENTOS}

\section{Ao meu orientador e grande mestre Prof. Dr. Leopoldino Capelozza Filho}

Dr. Dino, carinhosamente quero me dirigir a você, mestre, pois o admiro pela sabedoria e pela pessoa que é. Sou muito grata por ter sido sua aluna na especialização e orientanda no Mestrado. A forma como transmite seus conhecimentos me proporcionou uma visão diferenciada da Ortodontia. Que honra ter tido o Sr. como meu mestre. Muito obrigado.

\section{A Prof ${ }^{a}$. Dra. Terumi Okada Ozawa}

Quero lhe fazer um agradecimento especial. Foi através de você e da equipe do Centrinho que aprendi os primeiros passos na Ortodontia. Sua ajuda foi fundamental para que esta dissertação fosse concluída. Muito obrigada por estar sempre presente para me ouvir e me ajudar.

A todos os meus queridos professores e amigos da Ortodontia, Aiello, Araci, Rita, Dra. Arlete, Dra. Daniela Garib, Dra. Silvia e Dr. Omar

Além de amigos, vocês tem um lugar muito especial na minha vida, juntamente com Prof $^{\mathrm{a}}$.Terumi e Dr. Dino, pois com vocês aprendi a fazer Ortodontia e muito mais que isso a ter respeito pelos nossos pacientes. Que bom que o Centrinho conta com profissionais de tão alto nível.

\section{A minha querida amiga Bruna}

Amizade verdadeira se constrói dia-a-dia. Você foi companheira de mestrado e uma amiga muito presente com quem pude contar todas as vezes que precisei. Que bom ter feito este curso ao seu lado. Sua amizade foi essencial na conclusão dessa etapa de minha vida e desejo que possamos cultivar esse laço fraternal para sempre.

\section{A todos os profissionais do Setor de Ortodontia, Gleisieli, Thiago, Rogério, Adriano e Túlio}

Obrigada por toda a ajuda para o desenvolvimento desta pesquisa e pelo carinho com que sempre me trataram!

As auxiliares do Setor de Ortodontia, Denise, Soninha, Solange, Suzana, Marisaura, Celina e Letícia

Quero agradecer a todas vocês pela ajuda que me deram para a realização desse trabalho e pela amizade que temos deste os tempos da Preventiva. Adoro todas vocês. 



\section{Aos residentes do Setor de Ortodontia}

Obrigada pela ajuda e amizade de todos vocês!

Aos meus queridos amigos ortodontistas, William Zerbinatti, Rodrigo Forte, Guilherme Porciuncula, Juliana Borborema e todos os outros que encontrei durante minha passagem pela preventiva do HRAC e especialização da Profis

Obrigada por fazerem parte da minha vida. Adoro todos vocês!

\section{A minha auxiliar Karina}

Obrigada pela sua competência, amizade e por toda a colaboração em minha ausência no consultório. Você foi muito importante para a realização deste trabalho!

As minhas amigas e companheiras de trabalho Ana Paula, Ana Virgínia e Suzana

Quero agradecer a vocês pela amizade que têm demonstrado por mim. Eu as admiro pela competência e lealdade. Com certeza a rotina de trabalho se torna mais agradável com suas amizades. Adoro muito todas vocês.

Aos queridos amigos do Setor de Pós-Graduação do HRAC, Andréia, Rogério e Zezé

Vocês são pessoas extremamente competentes e atendem os alunos sempre com simpatia e boa vontade. A atitude de vocês, tirando nossas dúvidas sempre com paciência, fez com que o Mestrado tivesse um algo a mais. Que bom tê-los conhecido.

\section{A presidente da Pós-Graduação Profa. Dra. IngeTrindade}

Agradeço pela oportunidade e pelo exemplo de competência e dedicação que você nos dá! Obrigada por tudo!

\section{Aos meus colegas de Mestrado}

Obrigada pela ajuda e amizade de todos vocês!

\section{Ao Prof. David Normando}

Pela sua ajuda na realização das análises estatísticas, mesmo estando tão longe.

Aos pacientes e profissionais do HRAC

Meu eterno agradecimento! 



\section{RESUMO}

Razera FPM. Tomografia Computadorizada: Inclinação e angulação dos dentes anteriores em pacientes com fissura labiopalatina bilateral [dissertação]. Bauru: Hospital de Reabilitação de Anomalias Craniofaciais, Universidade de São Paulo; 2010.

Objetivos: Avaliação quantitativa e qualitativa de um método para mensuração das inclinações e angulações dentárias por meio de tomografia computadorizada e avaliação morfológica cãs estruturas dentárias nas imagens tomográficas em pacientes com fissura transforame incisivo bilateral.

Metodologia: Foram selecionados dez pacientes com fissura transforame bilateral em fase de contenção do tratamento ortodôntico para realização do exame tomográfico. Foram realizados cortes parassagitais no longo eixo dos dentes anteriores superiores e inferiores e a obtenção de uma imagem panorâmica a partir da TC para mensuração da inclinação e angulação dentária, respectivamente. As mensurações foram repetidas após um mês para cálculo do erro metodológico. As medidas feitas inicialmente foram denominadas M1 e as medidas repetidas após 1 mês M2.

Resultados: Os dados coletados foram submetidos à análise estatística para cálculo dos valores de média de M1 e M2, média total $(M 1+M 2 / 2)$ e desvio padrão da amostra e também aos testes de normalidade (Shapiro-Wilk), erro metodológico com a fórmula de Dahlberg e erro sistemático com teste t. Os dentes superiores apresentaram os valores mais discrepantes mostrando haver grande influência da fissura no posicionamento mésio-distal e vestíbulolingual ao final do tratamento ortodôntico. $\mathrm{O}$ arco inferior apresentou maior simetria e valores mais próximos daqueles encontrados na literatura mostrando haver pouca influência da fissura.

Conclusão: O exame tomográfico forneceu imagens de excelente qualidade para avaliação da relação dente/osso e a metodologia testada mostrou-se reproduzível com valores bastante próximos entre as duas medições.

Descritores: Tomografia, Ortodontia Corretiva, Fissura labiopalatina. 



\begin{abstract}
Razera FPM. Computed Tomography: Angulation and inclination of upper and lower anterior teeth in patients with bilateral cleft lip and palate [dissertation]. Bauru: Hospital de Reabilitação de Anomalias Craniofaciais, Universidade de São Paulo; 2010.
\end{abstract}

Objectives: (1) To evaluate tooth tipping and long axis angulation using computed tomography (CT), after orthodontic treatment in patients with bilateral cleft lip and palate. (2) Morphological evaluation of bone and dental structures and their relationship offered by CT. Methods: Ten patients with bilateral cleft lip and palate were select. Long axis' tomography cuts of all upper and lower anterior teeth and a panoramic view were obtained in order to measure tooth tipping and angulation. All measurements were repeated after one month (M1 and M2) and submitted to statistical analysis.

Results: The results showed no statistical differences between M1 and M2, however measurements for all upper teeth were higher compared to literature showing that for these patients, variation is rule not exception. Lower teeth measurements were much more uniform and predictable.

Conclusions: This method produced very accurate measurements and computed tomography provides high quality images to evaluate the relationship between roots and alveolar bone like no other source available.

Key words: tomography, orthodontics, cleft lip and cleft palate. 



\section{LISTA DE FIGURAS}

Figura 1 - (a) coroa anatômica; (b) coroa clínica.................................................. 38

Figura 2 - $\quad$ Eixo vestibular da coroa clínica.......................................................... 38

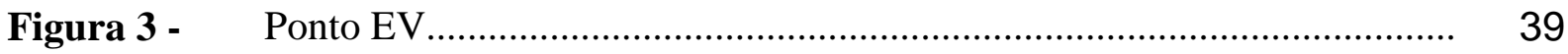

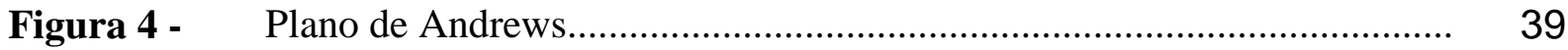

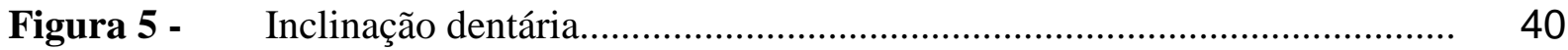

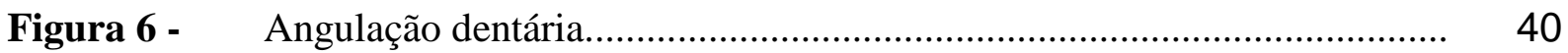

Figura 7 - $\quad$ Feixe de raios $\mathrm{X}$ tradicional (A) e feixe cônico (B)................................. 53

Figura 8 - $\quad$ Exemplos de fissura lábio-palatina bilateral completa............................ 58

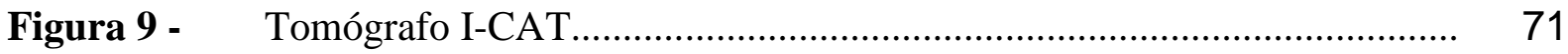

Figura 10 - Linhas guias para o posicionamento da cabeça do paciente..................... 72

Figura 11 - Método de incidência do feixe de Raios X obtida de Capelozza Filho et

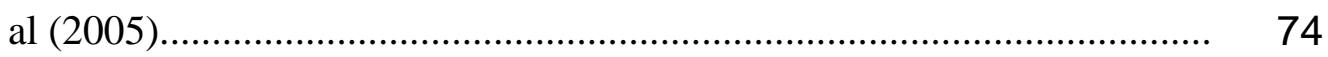

Figura 12 - $\quad$ Etapas para a obtenção dos cortes........................................................ 76

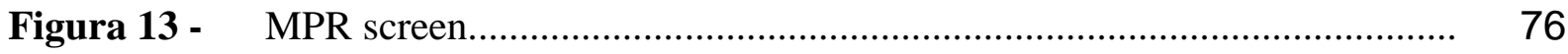

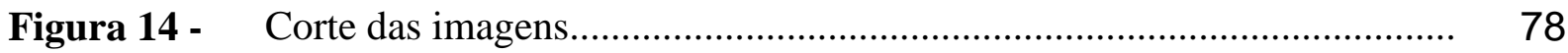

Figura 15 - Exemplo de imagem do dente a ser medido............................................ 79

Figura 16 - Plano de Andrews (Visão lado direito)................................................... 80

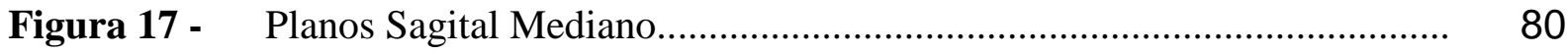

Figura 18 - $\quad$ Plano de Andrews (visão lado esquerdo).............................................. 80

Figura 19 - Etapas para a obtenção da panorâmica para medir a angulação................. 81

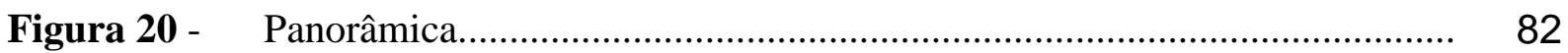

Figura 21 - Corte do incisivo central superior direito......................................... 82

Figura 22 - Coroa Anatômica................................................................................. 83

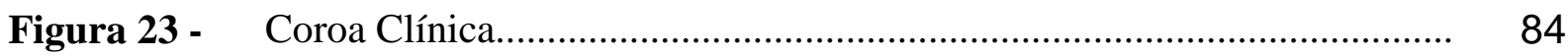




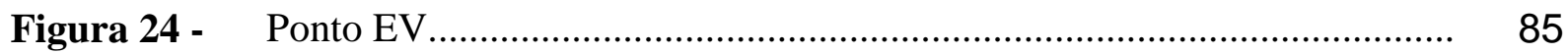

Figura 25 - Inclinação............................................................................. 86

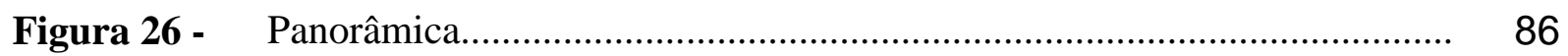

Figura 27 - Reta representando longo eixo do dente............................................. 87

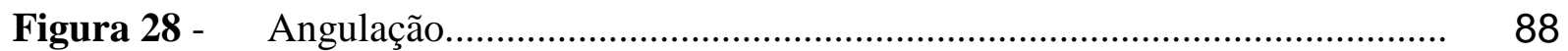

Figura 29 - Valores médios de inclinação e angulação na amostra selecionada.......... 92

Figura 30 - Perda do enxerto ósseo adjacente ao espaço protético.............................. 122

Figura 31 - Relação da raiz do canino superior com as tábuas ósseas vestibular e palatina.................................................................................. 144

Figura 32 - Relação da raiz do incisivo central superior com as tábuas ósseas vestibular e palatina.

Figura 33 - Relação da raiz dos dentes inferiores com as tábuas ósseas vestibular e

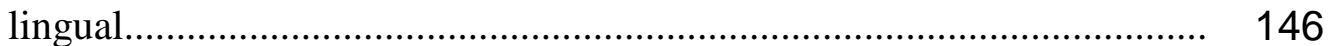

Figura 34 - Reabsorção radicular nos incisivos superiores e inferiores...................... 146

Figura 35 - Qualidade da imagem panorâmica...................................................... 147

Figura 36 - Reabsorção óssea horizontal............................................................. 147

Figura 37 - Centralização das raízes dos incisivos inferiores................................... 148

Figura 38 - Corte parassagital dos incisivos centrais superiores direito (a) e

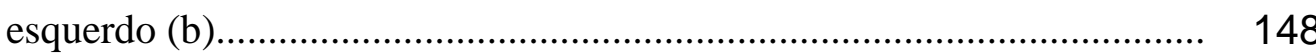

Figura 39 - $\quad$ Panorâmica de um paciente com presença do defeito ósseo alveolar bilateral.

Figura 40 - Panorâmica de um paciente com reabsorção óssea bilateral na área do enxerto.

Figura 41 - Cortes parassagitais dos incisivos centrais superiores direito (a) e esquerdo (b) 


\section{LISTA DE QUADROS}

Quadro 1 - Valores médios de inclinação e angulação no arco superior, segundo Andrews (1989).

Quadro 2 - Valores médios de inclinação e angulação no arco inferior, segundo Andrews (1989).

Quadro 3 - Prescrição Padrão I Capelozza Filho.

Quadro 4 - $\quad$ Prescrição Padrão II Capelozza Filho.

Quadro 5 - $\quad$ Prescrição Padrão III Capelozza Filho..................................................... 45

Quadro 6 - Sequência de seleção dos cortes.............................................................. 79

Quadro 7 - Valores médios de inclinação dos dentes 13 e 23 nos artigos de Andrews (1972), Zanelato (2006), Reis et al (2008) e na pesquisa atual

Quadro 8 - Valores médios de inclinação dos dentes 12 e 22 nos artigos de Andrews (1972), Zanelato (2006), Reis et al (2008) e na pesquisa atual

Quadro 9- Valores médios de inclinação dos dentes 11 e 21 nos artigos de Andrews (1972), Zanelato (2006), Reis et al (2008) e na pesquisa atual

Quadro 10 - Valores médios de inclinação dos dentes 33 e 43 nos artigos de Andrews (1972), Zanelato (2006), Reis et al (2008) e na pesquisa atual.

Quadro 11 - Valores médios de inclinação dos dentes 32, 31, 41 e 42 nos artigos de Andrews (1972), Zanelato (2006), Reis et al (2008) e na pesquisa atual

Quadro 12 - Valores médios de angulação dos dentes 13 e 23 nos artigos de Andrews (1972), Zanelato (2006), Reis et al (2008), Normando et al (2008), no livro de Ramos e Bramante (1997) e na pesquisa atual.

Quadro 13 - Valores médios de angulação dos dentes 12 e 22 nos artigos de Andrews (1972), Zanelato (2006), Reis et al (2008), no livro Ramos e Bramante (1997) e na pesquisa atual 
Quadro 14 - Valores médios de angulação dos dentes 11 e 21 nos artigos de Andrews (1972), Zanelato (2006), Reis et al (2008), no livro Ramos e Bramante (1997) e na pesquisa atual.

Quadro 15 - Valores médios de angulação dos dentes 32, 31, 41 e 42 nos artigos de Andrews (1972), Zanelato (2006), Reis et al (2008), no livro Ramos e Bramante (1997) e na pesquisa atual

Quadro 16 - Valores médios de angulação dos dentes 33 e 43 nos artigos de Andrews (1972), Zanelato (2006), Reis et al (2008), Normando et al (2008), no livro Ramos e Bramante (1997) e na pesquisa atual 


\section{LISTA DE TABELAS}

Tabela 1 - Testes estatísticos para coroa anatômica no arco superior......................... 93

Tabela 2 - Testes estatísticos para coroa clínica no arco superior.............................. 93

Tabela 3 - $\quad$ Testes estatísticos para ponto EV no arco superior................................... 94

Tabela 4 - Testes estatísticos para inclinação no arco superior................................... 94

Tabela 5 - $\quad$ Testes estatísticos para angulação no arco superior.................................. 95

Tabela 6 - Testes estatísticos para coroa anatômica no arco inferior.......................... 95

Tabela 7 - Testes estatísticos para coroa clínica no arco inferior............................... 96

Tabela 8 - Testes estatísticos para ponto EV no arco inferior................................... 96

Tabela 9 - Testes estatísticos para inclinação no arco inferior.................................... 97

Tabela 10 - Testes estatísticos para angulação no arco inferior................................... 97

Tabela 11 - Testes estatísticos para erro do método em coroa anatômica e coroa

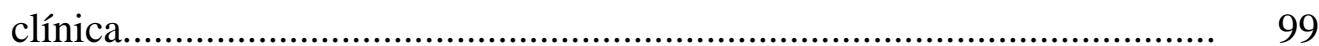

Tabela 12 - Testes estatísticos para erro do método em ponto EV ............................... 99

Tabela 13 - Testes estatísticos para erro do método em inclinação.............................. 100

Tabela 14 - $\quad$ Testes estatísticos para erro do método em angulação.............................. 100

Tabela 15 - $\quad$ Valores de M1, M2 e média de inclinação para os dentes 13 e 23........... 101

Tabela 16 - Valores de M1, M2 e média de inclinação para os dentes 12,11, 21 e

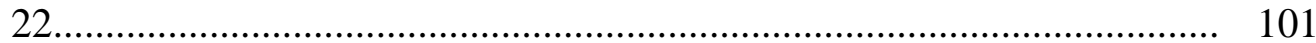

Tabela 17 - Valores de M1, M2 e média de inclinação para os dentes 33 e 43........... 102

Tabela 18 - Valores de M1, M2 e média de inclinação para os dentes 32, 31, 41 e 42.. 102

Tabela 19 - Valores de M1, M2 e média de angulação para os dentes 13 e 23............ 103

Tabela 20 - Valores de M1, M2 e média de angulação para os dentes 12,11, 21 e 22

Tabela 21 - V Valores de M1, M2 e média de angulação para os dentes 32, 31, 41 e 42.. $\quad 104$

Tabela 22 - $\quad$ Valores de M1, M2 e média de inclinação para os dentes 33 e 43........... 104 
Tabela 23 - Valores médios de inclinação dos dentes 13 e 23 para cada paciente....... 114

Tabela 24 - Valores médios de inclinação dos dentes 12 e 22 para cada paciente....... 117

Tabela 25 - Valores médios de inclinação dos dentes 11 e 21 para cada paciente....... 120

Tabela 26 - Valores médios de inclinação dos dentes 33 e 43 para cada paciente....... 124

Tabela 27 - Valores médios de inclinação dos dentes 32, 42, 31 e 41 para cada

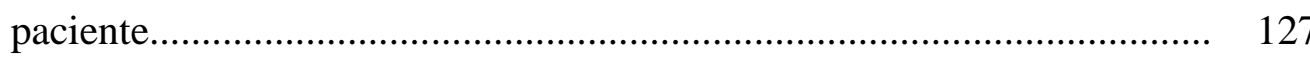

Tabela 28 - Valores médios de Angulação dos dentes 13 e 23 para cada paciente...... 131

Tabela 29 - Valores médios de Angulação dos dentes 12 e 22 para cada paciente...... 136

Tabela 30 - $\quad$ Valores médios de Angulação dos dentes 11 e 21 para cada paciente...... 138

Tabela 31 - Valores médios de angulação dos dentes 32, 42, 31 e 41 para cada

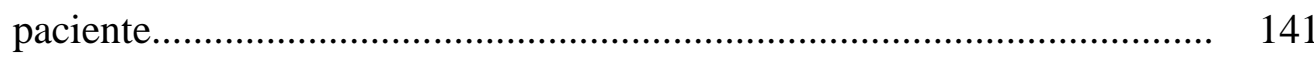

Tabela 32 - Valores médios de angulação dos dentes 33 e 43 para cada paciente....... 143 


\section{LISTA DE ABREVIATURAS}

ed. Edição

EVCC Eixo vestibular da coroa clínica

Fig. $\quad$ Figura

p. Página

Ponto EV Ponto do eixo vestibular

M1 Medida 1

M2 Medida 2

TC Tomografia Computadorizada

\section{LISTA DE SIGLAS}

FOB Faculdade de Odontologia de Bauru

HRAC Hospital de Reabilitação de Anomalias Craniofaciais

INMETRO Instituto Nacional de Metrologia, Normalização e Qualidade Industrial USP Universidade de São Paulo 



\section{SUMÁRIO}

1 INTRODUÇÃO

2 REVISÃO DE LITERATURA

2.1 LITERATURAS RELACIONADAS À MENSURAÇÃO DAS INCLINAÇÕES E ANGULAÇÕES DENTÁRIAS E À AVALIAÇÃO DAS ESTRUTURAS ÓSSEAS

2.2 LITERATURAS RELACIONADAS AOS PRINCÍPIOS DA TOMOGRAFIA COMPUTADORIZADA

2.3 LITERATURAS RELACIONADAS ÀS CARACTERÍSTICAS FACIAIS E DENTÁRIAS DOS PACIENTES COM FISSURA LABIOPALATINA BILATERAL COMPLETA …............................................................................... 57

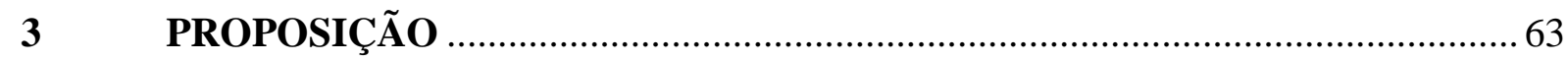

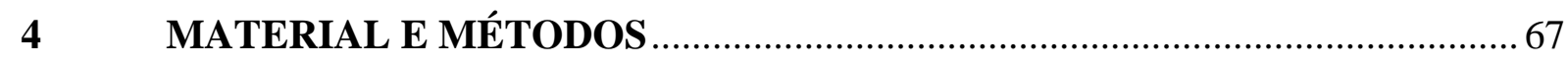

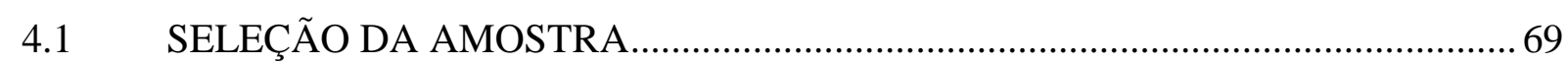

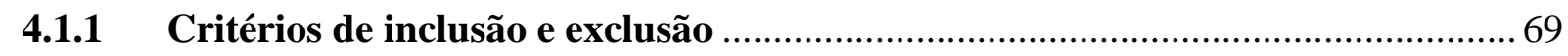

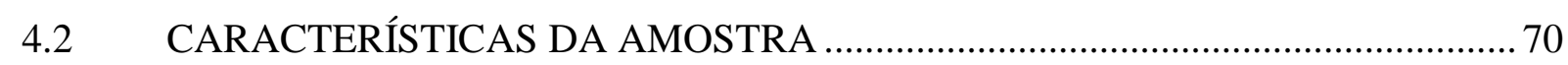

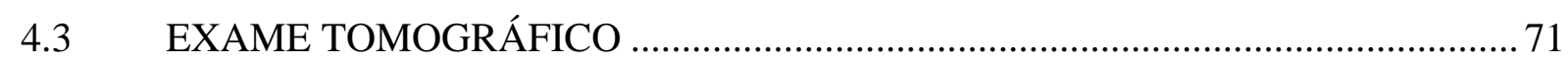

4.4 CARACTERÍSTICAS DO TOMÓGRAFO I-CAT .................................................. 73

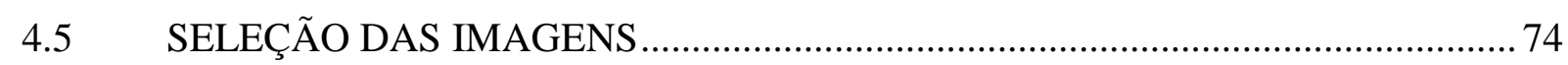

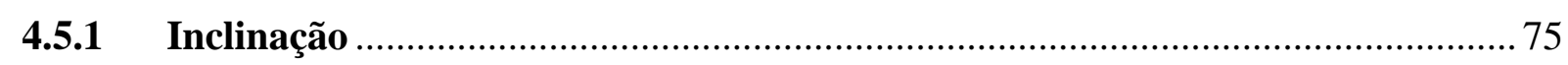

4.5.1.1 Posicionamento dos planos oclusal e plano de Andrews.......................................... 75

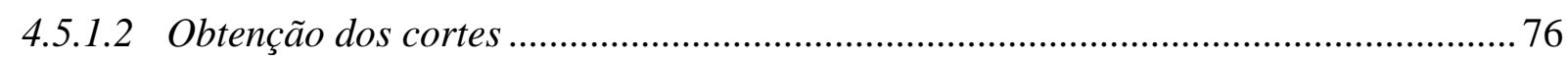

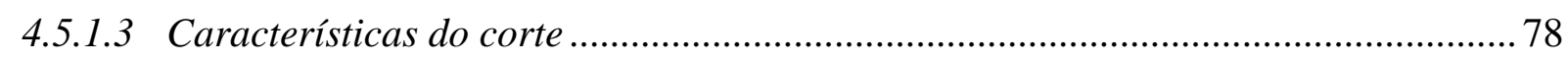

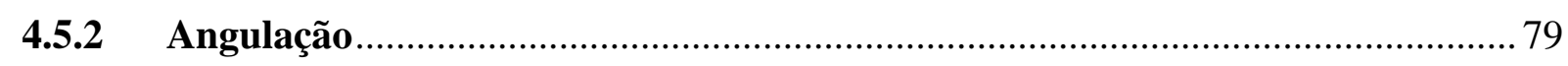

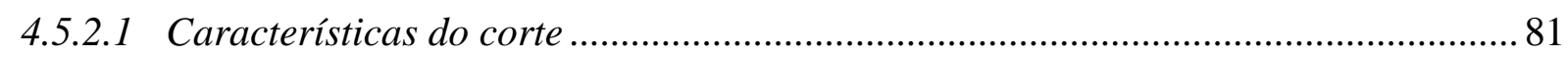

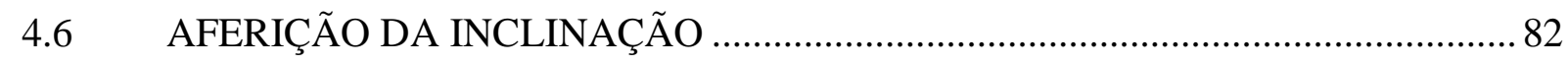

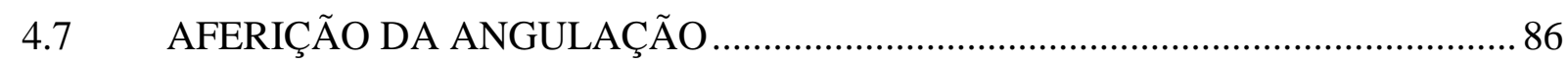

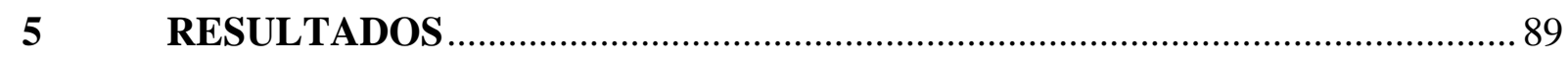

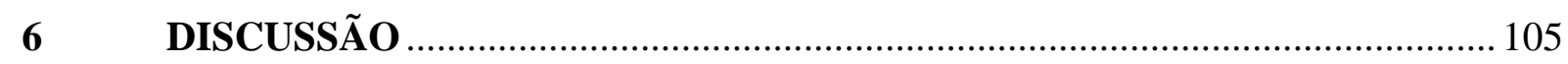

6.1 AVALIAÇÃO QUALITATIVA DO MÉTODO ................................................... 108

6.2 AVALIAÇÃO QUANTITATIVA DO MÉTODO ................................................ 110

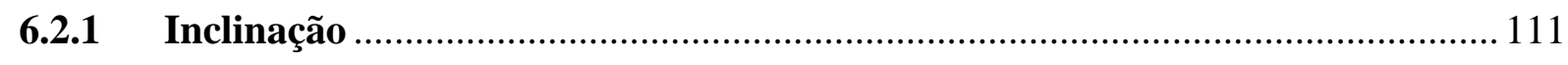




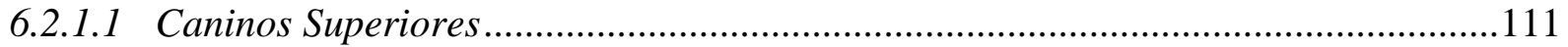

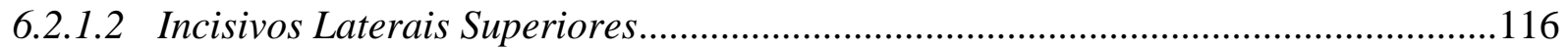

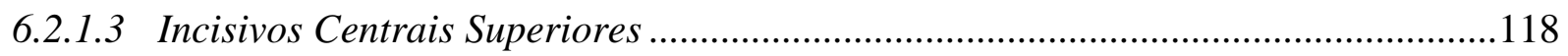

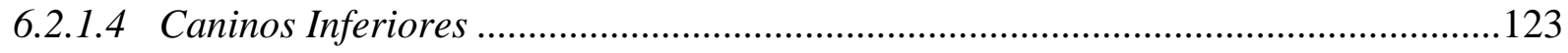

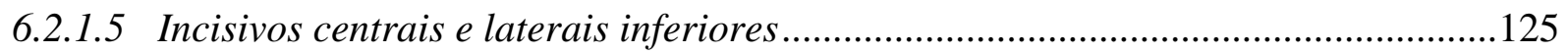

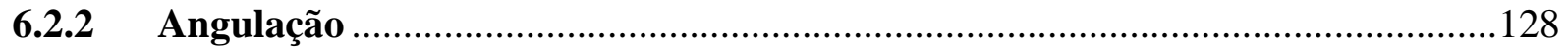

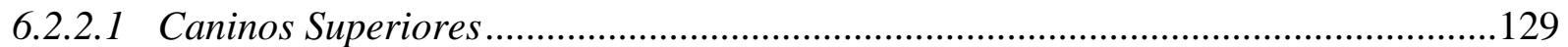

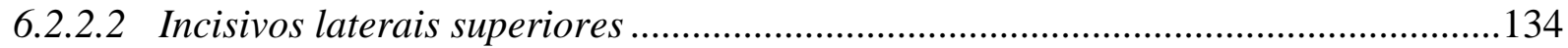

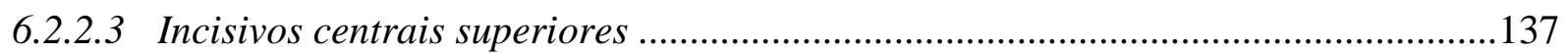

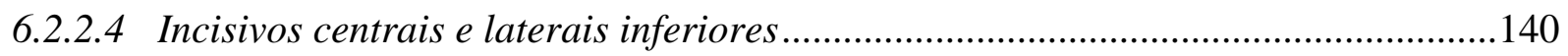

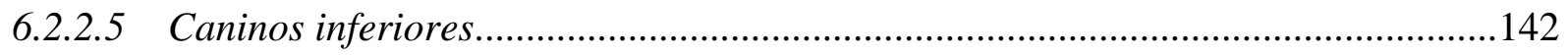

6.3 AVALIAÇÃO MORFOLÓGICA DAS ESTRUTURAS DENTÁRIAS ..................144

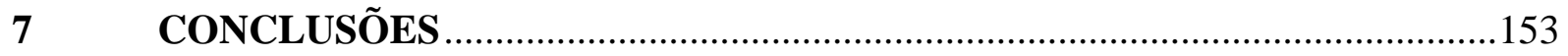

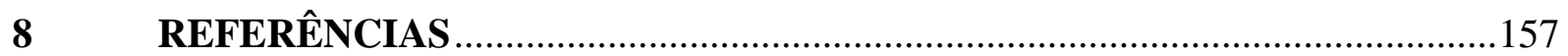

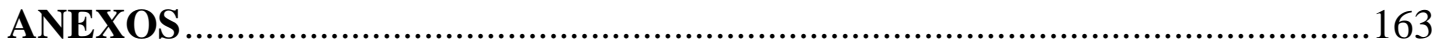





\section{INTRODUÇÃO}

Para as ciências da saúde, a possibilidade de "visualizar o invisível", aquelas estruturas que compõem um organismo no seu interior é algo tão imprescindível quanto notoriamente fascinante.

Em termos de diagnóstico por imagem, a evolução é extremamente recente e, ao mesmo tempo, tão grandiosa. Iniciada por Röentgen com a descoberta dos raios-x, no final do século XIX, ela continua a acontecer e hoje os recursos disponíveis possibilitam diagnósticos mais precisos e precoces, além do desenvolvimento de pesquisas inovadoras nessa área.

Uma importante tecnologia desenvolvida principalmente para a visualização do tecido ósseo e das estruturas mineralizadas é a tomografia computadorizada. Esse método de avaliação, que permite a geração de imagens tridimensionais e multiplanares com grande riqueza de detalhes e excelente qualidade de imagens, vem ganhando espaço na rotina clínica das diferentes especialidades da odontologia (Hatcher e Aboudara 2004).

Avaliar a inclinação e a angulação dentária antes e após o tratamento ortodôntico tem sido objeto de estudo de vários pesquisadores. Andrews (1972) mensurou tais variáveis em modelos de gesso de 120 pacientes com oclusão normal não tratada. A partir de seus achados, o autor desenvolveu uma nova linha de bráquetes, aos quais chamou de pré-programados (Straight-wire), embutindo as características de inclinação, angulação e torque encontradas nas oclusões normais. Uma revolução ocorreu na Ortodontia desde então, com novos estudos nessa linha de pesquisa, culminando com o desenvolvimento de outros bráquetes préprogramados como, por exemplo, prescrição Roth e Capelozza.

Nessa mesma linha de pesquisa, Zanelato (2003) estudou valores de inclinação e angulação de sessenta indivíduos brasileiros da etnia branca com oclusão normal natural em modelos de gesso. Os resultados mostraram que a maioria dos dentes apresentou uma 
angulação positiva e uma inclinação negativa, exceção à regra feita pelos incisivos superiores e laterais inferiores com valores de inclinação positivos. O autor concluiu que houve diferença estatisticamente significante entre os valores encontrados em seu trabalho e aqueles preconizados por Andrews.

Reis et al (2008) propuseram-se avaliar a inclinação e angulação dos pacientes com fissura transforame incisivo bilateral a partir de modelos de gesso dessas pacientes. Para os autores, os caninos e incisivos superiores foram os dentes mais afetados pela presença da fissura, enquanto que o arco inferior manteve valores mais uniformes devido à menor interferência da fissura. Os valores de inclinação negativos, em todo o arco inferior, somandose aos apinhamentos anteriores frequentes, sugerem a compensação inferior frente à uma maxila atrésica.

Muitos trabalhos têm utilizado modelos de gesso para aferição de tais variáveis devido à grande dificuldade encontrada na aferição das medidas em imagens radiográficas. A panorâmica pode ser utilizada para medir angulação assim como a telerradiografia para a inclinação. A sobreposição das estruturas anatômicas de um lado do crânio sobre o outro, em especial na telerradiografia, inviabiliza a mensuração dessas variáveis em imagens radiográficas convencionais. Partindo desse fato, os pesquisadores perceberam na tomografia tridimensional uma grande ferramenta auxiliar para aferição da inclinação e angulação com a grande vantagem de não haver sobreposição de estruturas anatômicas e, pelo contrario, permitindo a geração de imagens de excelente qualidade com cortes em quaisquer planos do espaço. Peck et al (2007) concluíram que as imagens obtidas a partir da tomografia computadorizada são bastante precisas para a avaliação da angulação dentária. Os autores compararam imagens tomográficas de feixe cônico de cinco modelos de gesso com as imagens panorâmicas dos mesmos modelos para a avaliação da angulação. Os resultados mostraram que a radiografia panorâmica não representou corretamente as angulações 
dentárias dos pacientes, diferentemente das imagens tomográficas, as quais forneceram dados muito confiáveis.

Para Capelozza Filho, Fattori e Maltagliari (2005), que utilizaram a tomografia computadorizada com a finalidade de avaliar inclinação e angulação, ela pode ser um meio útil para a avaliação das inclinações e angulações dentárias e para a individualização do tratamento ortodôntico por permitir a verificação individual do posicionamento dentário, além de contribuir para o desenvolvimento de pesquisas relacionadas ao posicionamento dentário.

Pela possibilidade de gerar imagens de alta resolução, com dimensões reais e precisas de qualquer parte da cavidade bucal e nas três dimensões do espaço é que esse método foi selecionado para o presente estudo, que se propôs mensurar a inclinação e angulação dentária em pacientes com fissura bilateral por meio da tomografia computadorizada. Essas variáveis já foram mensuradas anteriormente em outros estudos utilizando modelos de gesso ou radiografias convencionais, mas com limitação de técnica e qualidade de imagem que serão discutidas no decorrer do estudo. Não há, até o momento, um trabalho semelhante realizado em pacientes com fissura e, portanto, esta pesquisa permitirá que outros caminhos se abram às novas pesquisas que venham contribuir com o longo caminho percorrido pelo processo reabilitador que envolve o tratamento dos pacientes com fissura lábio-palatina. 



\section{REVISÃO DE LITERATURA}





\section{REVISÃO DE LITERATURA}

A Ortodontia, como especialidade, sempre buscou a correção das más oclusões através do correto posicionamento dentário. No começo do século passado, por volta de 1920, Angle, considerado o pai da Ortodontia, desenvolveu um aparelho intrabucal que consistia em uma peça de metal posicionada na face vestibular de cada dente. A peça, chamada de bráquete, possuía uma canaleta no centro na qual um fio de aço era inserido de modo a movimentar o dente mal alinhado e posicioná-lo perfeitamente na arcada dentária. A esse aparelho Angle deu o nome de Edgewise ou, como também ficou conhecida a sua versão traduzida para o português, arco de canto. Em termos técnicos, sua função era atuar diretamente nas inclinações e angulações dentárias quando o fio ortodôntico era inserido nas canaletas dos bráquetes (Graber 1996).

Algumas décadas antes do desenvolvimento do aparelho Edgewise, Röentgen havia descoberto os raios-x e a união desses dois acontecimentos revolucionou a ciência da Ortodontia.

Com o advento da era radiológica na odontologia, em meados do século passado, vários estudiosos da área, como Tweed, Steiner, McNamara, Rickets e outros (Jacobson 1995), puderam utilizar as radiografias laterais da face (telerradiografias) para a realização de pesquisas científicas. Essas pesquisas tinham por finalidade determinar medidas cefalométricas para a relação das bases ósseas entre si e com o crânio, e para a correta inclinação dos incisivos superiores e inferiores ao final do tratamento ortodôntico, baseada nos valores médios encontrados em indivíduos considerados portadores de uma oclusão normal. O conjunto dessas medidas, chamado de análise cefalométrica, serviria como referência aos ortodontistas tanto no planejamento ortodôntico de seus pacientes como na finalização dos tratamentos. Cada pesquisador criou seu próprio conjunto de medidas como, 
por exemplo, análise cefalométrica de Rickets, de Steiner, de McNamara e, por muitos anos, a Ortodontia se baseou nesses valores como meta ideal de tratamento para todos os pacientes. Atualmente, a telerradiografia e a cefalometria têm seu valor clínico mais como um método auxiliar de diagnóstico de modo a oferecer subsídios para o planejamento ortodôntico juntamente com a análise facial individual de cada paciente e não como um conjunto de medidas que determinam metas terapêuticas.

\subsection{LITERATURAS RELACIONADAS À MENSURAÇÃO DAS INCLINAÇÕES E ANGULAÇÕES DENTÁRIAS E À AVALIAÇÃO DAS ESTRUTURAS ÓSSEAS}

Anos mais tarde, Andrews (1976), considerando que todo tratamento ortodôntico deveria se basear em objetivos oclusais e não em medidas cefalométricas, publicou o primeiro artigo de uma série de estudos sobre um novo tipo de aparelho ortodôntico que ele havia desenvolvido em 1972. Para o autor, todo tratamento deveria ter como meta a ser atingida os princípios oclusais e funcionais observados nas oclusões normais naturais, pois, para ele, a natureza produz sempre os melhores resultados. Para tanto selecionou 120 modelos de gesso de indivíduos que apresentavam oclusões normais naturais (sem tratamento ortodôntico prévio) e determinou as relações ideais que os dentes deveriam manter entre si e entre os arcos dentários ao final do tratamento, incluindo a inclinação e angulação dentária. Esse estudo possibilitou ao autor o estabelecimento das seis chaves da oclusão normal servindo como parâmetro para a finalização ideal dos tratamentos ortodônticos. Andrews, de uma maneira perspicaz, inovou quando percebeu que poderia embutir nos bráquetes do aparelho Edgewise as características que compõem as seis chaves da oclusão normal. Não havia ainda aparelho semelhante, na Ortodontia, em relação ao conceito de oclusão normal e em relação aos resultados de tratamento. Ele foi idealizado para cada dente de cada paciente individualmente, conferindo-lhe características como inclinação vestíbulo-lingual, angulação 
mésio-distal, proeminência vestibular da coroa dentária, compensação do molar superior, contorno facilmente adaptável à superfície vestibular, entre outras. Esse novo tipo de aparelho, agora com bráquetes pré-programados, recebeu o nome de Straight-wire, cuja tradução significa arco reto, uma vez que, segundo Andrews, não seriam necessárias dobras no fio ortodôntico para a finalização dos tratamentos.

Ainda em 1976, no segundo artigo da série, Andrews enfatizou a importância de haver um ponto de referência para o correto posicionamento dos bráquetes na face vestibular, comum a todos os dentes. Ele observou que muitos ortodontistas possuíam pontos de referência diferentes, e que isso afetaria os resultados obtidos uma vez que o aparelho fora desenvolvido para ser posicionado no centro da coroa clínica de cada dente equidistante das faces mesial e distal e das faces cervical e oclusal ou borda incisal.

No artigo seguinte da série, Andrews (1976) relatou como o aparelho Straight-wire funcionava, sem dobras nos fios, em quatro casos tratados sem extração de dentes. Mostrou que os tratamentos foram efetivos e as metas relacionadas às seis chaves de oclusão e a cefalometria foram atingidas.

No último artigo da série, Andrews (1976) tratou dos problemas enfrentados pelo aparelho Straight-wire nos casos que envolviam extrações dentárias. Segundo o autor, o aparelho padrão é indicado principalmente para os casos tratados sem extrações e que, naqueles onde elas seriam necessárias, dobras de todas as ordens deveriam ser confeccionadas de modo a atingir os objetivos de tratamento. A partir de então, Andrews modificou algumas características dos bráquetes para os casos com exodontia, conferindo-lhes características de antirrotação e antiangulação a serem dadas aos dentes adjacentes ao espaço da extração. Essas modificações opunham-se aos efeitos de rotação e angulação que esses dentes sofrem quando uma força ortodôntica é aplicada fora do seu centro de resistência, o que ocorre nos movimentos de translação para fechamento de espaço. 
Em 1989, Andrews publicou um livro a respeito de todos os estudos realizados para o desenvolvimento da técnica Straight-wire. Nele o autor descreve, passo a passo, como foram feitas as medidas de inclinação, angulação, in-set e off-set nos 120 modelos de gesso de oclusões normais naturais, além de explicar os conceitos e pontos de referência utilizados na determinação das seis chaves de oclusão normal.

Coroa anatômica: Distância entre a borda incisal ou face oclusal e a junção amelocementária (Fig.1a).

Coroa clínica: Parte da coroa dentária que é vista clinicamente. Segundo Orban (1957), citado por Andrews (1989), o tamanho da coroa clínica é dado pela subtração de 1,8mm da coroa anatômica (Fig.1b).

(a)

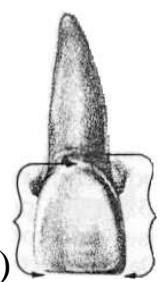

(b)

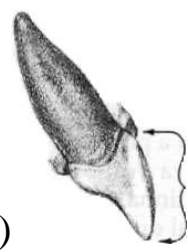

Figura 1 - (a) coroa anatômica; (b) coroa clínica.

Eixo vestibular da coroa clínica (EVCC): porção mais proeminente do lóbulo central da face vestibular, exceto para os molares, o qual caracteriza o eixo em seu sulco central vestibular (Fig. 2).

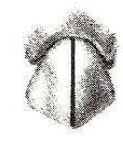

a

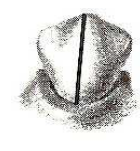

a

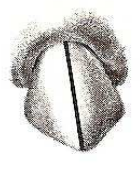

b
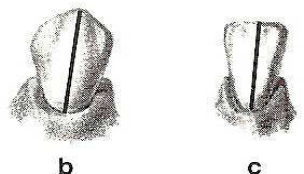

c

Figura 2 - Eixo vestibular da coroa clínica. 


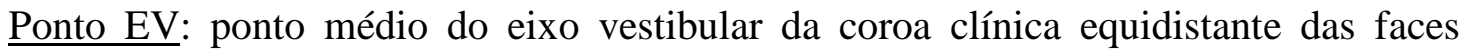
mésio-distal e das faces cérvico-incisal para os dentes anteriores, ou cérvico-oclusal para os dentes posteriores.

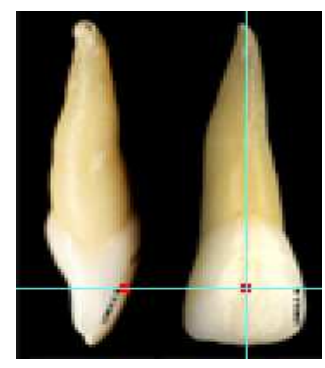

Figura 3 - Ponto EV.

Plano de Andrews: superfície com a qual o plano médio transverso de cada coroa coincidirá quando os dentes estiverem idealmente posicionados.

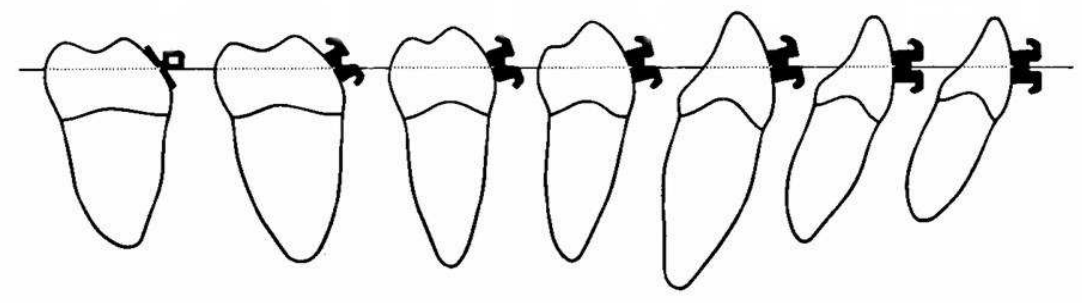

Figura 4 - Plano de Andrews.

Inclinação dentária: ângulo formado no sentido vestíbulo-lingual entre o eixo vestibular da coroa clínica e uma linha perpendicular ao plano de Andrews, ambos passando pelo ponto EV. 


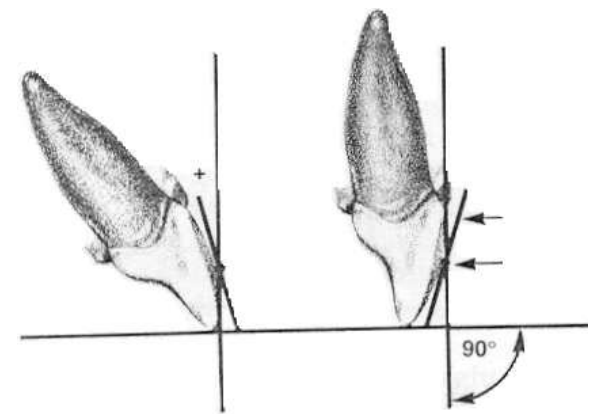

Figura 5 - Inclinação dentária.

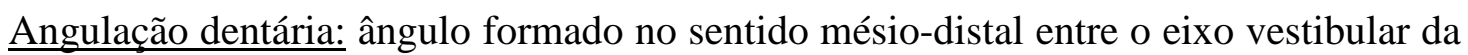
coroa clínica e uma linha perpendicular ao plano de Andrews, ambos passando pelo ponto EV.

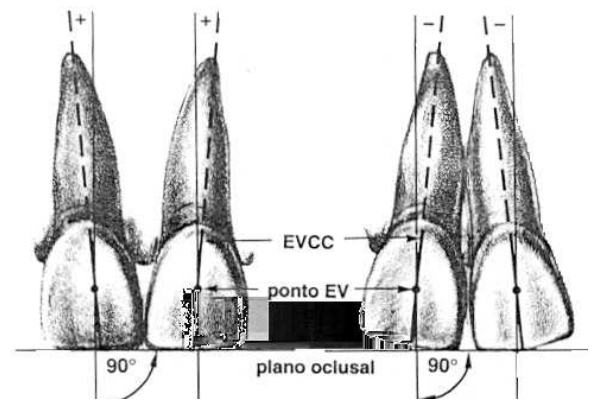

Figura 6 - Angulação dentária.

Nesse livro, o autor definiu as seis chaves de oclusão como sendo: inclinação e angulação da coroa, pontos de contato juntos, curva de spee normal, ausência de rotações dentárias e relação interarcos. Além disso, descreveu a metodologia utilizada para mensuração da inclinação e angulação dentária da seguinte forma: para cada dente da arcada, foi definido o EVCC (eixo vestibular da coroa clínica) e determinada a exata localização do ponto EV no centro da coroa clínica, sobre o EVCC, equidistante das faces cérvico-incisal/oclusal e das faces mésio-distal. Um gabarito oclusal foi utilizado apoiado na superfície oclusal dos dentes, representando o plano oclusal. Com o auxílio de um transferidor, com braço ajustável, foram 
medidos os valores de inclinação e angulação das coroas dentárias de todos os dentes. A base do transferidor foi apoiada sobre o gabarito oclusal, e o seu braço ajustável foi posicionado de modo a coincidir com o eixo vestibular da coroa clínica. $\mathrm{O}$ valor do ângulo formado pela reta perpendicular ao plano oclusal e pela reta coincidente com EVCC representou o valor da angulação para aquele dente. Para a mensuração da inclinação, o mesmo transferidor foi apoiado sobre o plano oclusal no sentido vestíbulo-lingual. Seu braço de leitura foi ajustado de modo a ficar paralelo ao EVCC, tangenciando o maior número de pontos na face vestibular, passando pelo ponto EV. O valor do ângulo obtido representou a inclinação coronária para aquele dente. Seguem, no quadro abaixo, os valores médios de inclinação e angulação encontrados pelo autor para os dentes superiores e inferiores.

Quadro 1 - Valores médios de inclinação e angulação no arco superior, segundo Andrews (1989).

\begin{tabular}{|c|c|c|c|c|c|c|c|}
\hline & \multicolumn{7}{|c|}{ Arco Superior } \\
\cline { 2 - 8 } & IC & IL & C & 1PM & 2PM & 1M & 2M \\
\hline Inclinação & $6,11^{\circ}$ & $4,42^{\circ}$ & $-7,25^{\circ}$ & $-8,47^{\circ}$ & $-8,78^{\circ}$ & $-11,53^{\circ}$ & $-8,10^{\circ}$ \\
\hline Angulação & $3,59^{\circ}$ & $8,04^{\circ}$ & $8,40^{\circ}$ & $2,65^{\circ}$ & $2,82^{\circ}$ & $5,73^{\circ}$ & $0,39^{\circ}$ \\
\hline
\end{tabular}

Quadro 2 - Valores médios de inclinação e angulação no arco inferior, segundo Andrews (1989).

\begin{tabular}{|l|c|c|c|c|c|c|c|}
\hline \multirow{2}{*}{} & \multicolumn{7}{|c|}{ Arco Inferior } \\
\cline { 2 - 8 } & IC & IL & C & 1PM & 2PM & 1M & 2M \\
\hline Inclinação & $-1,71^{\circ}$ & $-3,24^{\circ}$ & $-12,73^{\circ}$ & $-18,95^{\circ}$ & $-23,63^{\circ}$ & $-30,67^{\circ}$ & $-36,03^{\circ}$ \\
\hline Angulação & $0,53^{\circ}$ & $0,38^{\circ}$ & $2,48^{\circ}$ & $1,28^{\circ}$ & $1,54^{\circ}$ & $2,03^{\circ}$ & $2,94^{\circ}$ \\
\hline
\end{tabular}

Andrews também observou que valores atribuídos aos incisivos variavam, mesmo em oclusões normais, e que essa característica pode ser atribuída aos padrões esqueletais diferentes presentes nessas oclusões. Assim, o autor introduziu o aparelho Straight-wire na 
Ortodontia e sugeriu que houvesse três prescrições com valores diferentes para a inclinação dos incisivos superiores e inferiores, de modo a acomodar as relações intermaxilares de classe I, II e III.

Após a sua introdução, ele vem sendo aprimorado por vários pesquisadores, embutindo-lhe características diversas no intuito de aperfeiçoar a finalização dos tratamentos.

Roth (1987), por exemplo, realizou uma análise da técnica original proposta por Andrews, e descreveu suas experiências clínicas com o aparelho Straight-wire. Segundo o autor, a prescrição padrão foi criada para os casos tratados sem extração e com ANB menor que $5^{\circ}$. Há ainda, as prescrições para casos tratados com extração, com necessidade de ancoragens adicionais e para diferentes valores de ANB. Roth imaginou se não seria possível criar uma única prescrição para ser usada na maioria dos casos e que ainda promovesse a sobrecorreção para os casos com tendência a recidivas. Ele modificou a prescrição original criando a sua própria prescrição, justificando a necessidade de incorporar movimentos de antirrotação, anti-inclinação e antiangulação e diminuir a curva de spee, de modo a minimizar a recidiva, sobrecorrigindo as posições dentárias em todos os planos do espaço. Essa prescrição, segundo o autor, resolveria os problemas causados pelos efeitos indesejáveis da técnica Straight-wire, como a necessidade de ancoragens adicionais nos casos de extração pela tendência de mesialização das coroas dentárias que as inclinações promoviam, além da necessidade de curva compensatória no arco superior e curva reversa no arco inferior. Roth enfatizou que algumas características da técnica original, como melhores resultados e tempo de tratamento mais curto, são alcançadas pelas características do bráquete pré-programado no controle da inclinação, angulação, rotação e proeminência vestibular (in/off). O autor conclui afirmando que, pela sua experiência, a técnica Straight-wire não faz diagnóstico nem plano de tratamento, mas quando bem executada levará os dentes para posições melhores em menor tempo e com bons resultados. 
Capelozza Filho et al (1999), baseados em suas experiências clínicas, publicaram um artigo a respeito da individualização do tratamento ortodôntico pela técnica Straight-wire, realizando uma revisão dos conceitos propostos por Andrews e sugerindo três prescrições de bráquetes considerando o tipo de tratamento a ser instituído, as características da má-oclusão e o posicionamento desejado ou possível para os dentes ao final do tratamento. Segundo os autores, o melhor tratamento a ser adotado para a correção de uma má-oclusão, incluindo a mecânica a ser desenvolvida, dependeria de fatores como o tipo de má-oclusão a ser tratada e dos objetivos definidos pelo tratamento. Analisada sob as perspectivas de localização, gravidade e etiologia e das características individuais de seu portador, com destaque à idade e queixa ou à aspiração do paciente com o tratamento, plano e metas seriam definidos. Individualizar bráquetes significa considerar a posição que os dentes deverão idealmente ocupar ao final do tratamento. Seguindo esses preceitos, Capelozza Filho et al (1999) sugeriram a individualização para a finalização, uma vez que, potencialmente, mais de $50 \%$ dos casos necessitam de tratamento compensatório e, portanto, de bráquetes com prescrição diferenciada. Os autores sugeriram, também, três diferentes prescrições para o tratamento dos padrões I, II e III.

Para a prescrição padrão, os bráquetes recomendados seguem basicamente os valores da prescrição padrão de Andrews, com exceções feitas aos caninos superiores, que apresentam uma angulação e inclinação diminuídas de $11^{\circ}$ para $8^{\circ}$ e $7^{\circ}$ para $5^{\circ}$, respectivamente, aos pré-molares e $1 .^{\circ}$ molares superiores com valores de angulação de $0^{\circ}$ e a diminuição da inclinação dos molares inferiores. 
Quadro 3 - Prescrição Padrão I Capelozza Filho.

\begin{tabular}{|c|c|c|c|c|c|c|c|c|c|c|}
\hline \multirow{2}{*}{$\begin{array}{l}\text { PRESCRIÇÃO } \\
\text { PADRÃO I }\end{array}$} & \multicolumn{5}{|c|}{ DENTES SUPERIORES } & \multicolumn{5}{|c|}{ DENTES INFERIORES } \\
\hline & IC & IL & $C$ & PM & $M$ & ICE IL & C & $1^{\circ} \mathrm{PM}$ & $2^{\circ} \mathrm{PM}$ & $M$ \\
\hline INCLINAÇÃO & $+7^{\circ}$ & $+3^{\circ}$ & $-5^{\circ}$ & $-7^{\circ}$ & $-10^{\circ}$ & $-1^{\circ}$ & $-11^{\circ}$ & $-17^{\circ}$ & $-22^{\circ}$ & $-25^{\circ}$ \\
\hline ANGULAÇÃO & $+5^{\circ}$ & $+9^{\circ}$ & $+8^{\circ}$ & $0^{\circ}$ & $0^{\circ}$ & $+2^{\circ}$ & $+5^{\circ}$ & $+2^{\circ}$ & $+2^{\circ}$ & $0^{\circ}$ \\
\hline
\end{tabular}

Para a prescrição padrão II, os valores de inclinação dos incisivos inferiores promovem uma vestibularização acentuada desses dentes, de modo a compensar o erro esquelético e, consequentemente,um aumento no comprimento do arco inferior pela mesialização de todo o seguimento posterior e diminuição ou manutenção no perímetro do arco superior pela menor angulação dos caninos, muitas vezes já presentes pelas próprias compensações naturais do padrão II. Sua indicação principal está voltada para o tratamento compensatório da deficiência mandibular presente no padrão II.

Quadro 4 - Prescrição Padrão II Capelozza Filho.

\begin{tabular}{|c|c|c|c|c|c|c|c|c|c|c|}
\hline \multirow{2}{*}{$\begin{array}{l}\text { PRESCRIÇÃO } \\
\text { PADRÃO II }\end{array}$} & \multicolumn{5}{|c|}{ DENTES SUPERIORES } & \multicolumn{5}{|c|}{ DENTES INFERIORES } \\
\hline & IC & IL & $\mathrm{C}$ & PM & $M$ & IC E IL & $\mathrm{C}$ & $1^{\circ} \mathrm{PM}$ & $2^{\circ} \mathrm{PM}$ & $M$ \\
\hline INCLINAÇÃO & $+7^{\circ}$ & $+3^{\circ}$ & $-5^{\circ}$ & $-7^{\circ}$ & $-10^{\circ}$ & $+4^{\circ}$ & $-11^{\circ}$ & $-17^{\circ}$ & $-22^{\circ}$ & $-25^{\circ}$ \\
\hline ANGULAÇÃO & $+5^{\circ}$ & $+9^{\circ}$ & $+5^{\circ}$ & $0^{\circ}$ & $0^{\circ}$ & $+2^{\circ}$ & $+5^{\circ}$ & $+2^{\circ}$ & $+2^{\circ}$ & $0^{\circ}$ \\
\hline
\end{tabular}

Para a prescrição padrão III, de forma inversa da que ocorre para a prescrição padrão II, esse tipo de prescrição procura preservar ou diminuir o perímetro do arco inferior, á custa de uma menor angulação dos caninos e incisivos inferiores, que passam a apresentar valores de angulação de $0^{\circ}$ e valores de inclinação negativos. Para os caninos superiores, a prescrição sugere valores de angulação de $11^{\circ}$ e valores de inclinação aumentados para os dentes 
anteriores de tal modo a compensar a relação maxilo-mandibular prejudicada na presença da discrepância esquelética.

Quadro 5 - Prescrição Padrão III Capelozza Filho.

\begin{tabular}{|l|c|c|c|c|c|c|c|c|c|c||}
\hline \multirow{2}{*}{ PRESCRIÇÃO } & \multicolumn{5}{|c|}{ DENTES SUPERIORES } & \multicolumn{5}{c||}{ DENTES INFERIORES } \\
\cline { 2 - 12 } & IC & IL & C & PM & M & IC E IL & C & $1^{\circ} \mathrm{PM}$ & $2^{\circ} \mathrm{PM}$ & $\mathrm{M}$ \\
\hline INCLINAÇÃO & $+14^{\circ}$ & $+10^{\circ}$ & $-2^{\circ}$ & $-7^{\circ}$ & $-10^{\circ}$ & $-6^{\circ}$ & $-11^{\circ}$ & $-17^{\circ}$ & $-22^{\circ}$ & $-25^{\circ}$ \\
\hline ANGULAÇÃO & $+5^{\circ}$ & $+9^{\circ}$ & $+11^{\circ}$ & $0^{\circ}$ & $0^{\circ}$ & $0^{\circ}$ & $0^{\circ}$ & $+2^{\circ}$ & $+2^{\circ}$ & $0^{\circ}$ \\
\hline
\end{tabular}

Segundo Capelozza Filho, Fattori e Maltagliari (2005), são escassos os trabalhos na literatura que avaliaram as inclinações e angulações dentárias individuais bem como a finalização e impressão dos torques e angulações propostos pelas diferentes prescrições. Os autores publicaram um artigo descrevendo uma nova metodologia para a mensuração da inclinação e angulação dentária por meio da tomografia computadorizada em dois pacientes, sendo um classificado de acordo com o padrão II e o outro com o padrão III. Foram realizados cortes tomográficos dos dentes anteriores superiores e inferiores, e as mensurações de inclinação e angulação desses dentes. Os autores concluíram que a tomografia computadorizada pode ser um meio útil para a avaliação das inclinações e angulações dentárias e para a individualização do tratamento ortodôntico por permitir a verificação individual do posicionamento dentário, além de contribuir para o desenvolvimento de pesquisas relacionadas ao posicionamento dentário.

Nessa mesma linha de pesquisa, Zanelato (2003) estudou valores de inclinação e angulação de sessenta indivíduos brasileiros da etnia branca, com oclusão normal natural (sem tratamento ortodôntico prévio), e comparou os resultados com os valores encontrados por Andrews (1989). Para a aferição das inclinações e angulações dentárias, o autor utilizou modelos de gesso de cada paciente. Os resultados mostraram que a maioria dos dentes 
apresentou uma angulação positiva e uma inclinação negativa, exceção à regra feita pelos incisivos superiores e laterais inferiores, com valores de inclinação positivos. O autor concluiu que houve diferença estatisticamente significante entre os valores encontrados em seu trabalho com aqueles preconizados por Andrews.

Guedes, Gondim e Cimões (2007) propuseram-se, também, a avaliar as angulações e inclinações dentárias em más-oclusões de Classe I não tratadas e compará-las com as médias obtidas por Andrews, em seu estudo, em relação às seis chaves da oclusão normal, o qual proporcionou o estabelecimento de valores médios de inclinação e angulação dentária e o desenvolvimento da técnica Straight-wire. Para isso, os autores selecionaram trinta pares de modelos de gesso em dentadura permanente de pacientes de ambos os sexos. As angulações e inclinações foram medidas utilizando-se um transferidor com haste central, apoiado sobre um gabarito oclusal em acrílico, conforme técnica proposta por Andrews. Os resultados mostraram que as angulações na Classe I foram, em sua maioria, positivas, exceto para os incisivos laterais inferiores. As inclinações também variaram nas médias, em relação aos valores encontrados por Andrews, divergindo apenas para os incisivos centrais inferiores. Os autores concluem que os valores médios das angulações obtidos nesse estudo foram semelhantes aos obtidos por Andrews.

Reis et al (2008) publicaram um artigo sobre a avaliação e mensuração da inclinação e angulação dentária em pacientes com fissura transforame incisivo bilateral, no intuito de determinar características comuns a esses pacientes. Para tanto, foram selecionados, aleatoriamente, a partir do arquivo do Hospital de Reabilitação de Anomalias Craniofaciais da Universidade de São Paulo (HRAC-USP), trinta pares de modelos de gesso dos arcos dentários de pacientes operados, portadores desse tipo de fissura e em estágio de dentadura permanente, com idades entre 12 e 27 anos. Os modelos foram preparados e as medidas realizadas, baseando-se na metodologia proposta por Andrews (1989). Os resultados obtidos 
para o arco superior mostraram valores positivos de angulação com tendência crescente progressiva de molares para caninos e para os incisivos, valores negativos denotando raízes contra-anguladas. No arco inferior, os valores encontrados foram positivos, decrescentes de molares para pré-molares e negativos em toda a região anterior. Com relação à inclinação, foram observados valores negativos, correspondentes à inclinação palatina ou lingual, para todos os dentes da amostra. Os autores concluíram que os caninos e incisivos superiores foram os dentes mais afetados pela presença da fissura, enquanto que o arco inferior manteve valores mais uniformes, devido à menor interferência da fissura Os valores de inclinação negativos em todo o arco inferior, somando-se aos apinhamentos anteriores freqüentes sugerem a compensação inferior no que se refere à uma maxila atrésica.

Em 2008, Normando, Azevedo e Torres propuseram um método para determinar as angulações mésio-distais das coroas dos caninos em indivíduos portadores de má oclusão de classe III, comparando-os a indivíduos portadores de classe I, através de medidas tomadas em fotografias digitalizadas de modelos de gesso e transportadas para um programa gráfico para a leitura das medidas (Image Tool). Tais procedimentos foram repetidos para a avaliação do erro do método casual (fórmula de Dahlberg) e para a análise da reprodutibilidade através da correlação intraclasse. A amostra constituiu-se de 57 pacientes com dentição permanente completa e não tratados ortodonticamente, dividida em dois grupos, de acordo com a máoclusão apresentada. O grupo I era constituído de trinta e três pacientes portadores de máoclusão de classe I, sendo 16 do sexo masculino e 17 do feminino, com média de idade de 27 anos. O grupo II era representado por vinte e quatro pacientes portadores de má-oclusão de classe III, 20 do sexo masculino e 04 do feminino, com média de idade de 22 anos. $\mathrm{O}$ erro casual mostrou-se com uma variação de 1,54 a 1,96 graus para a angulação dos caninos. Em relação à reprodutibilidade do método, a análise estatística revelou que o método apresenta uma excelente reprodutibilidade $(\mathrm{p}<0.01)$. Os resultados obtidos na angulação da coroa dos 
caninos não mostraram diferenças estatisticamente significantes entre os caninos superiores nos grupos classe I e classe III, embora esse dente mostrasse, em média, uma angulação $2^{\circ}$ maior nos indivíduos classe III. Entretanto, para os caninos inferiores, foi observada uma diferença estatisticamente significante em ambos os lados $(\mathrm{p}=0,0009$ e $\mathrm{p}=0,0074)$, entre os grupos classe I e classe III. Os pacientes classe III apresentaram uma menor angulação nos caninos inferiores em comparação aos pacientes classe I, tendendo a acompanhar a compensação natural dos incisivos descritos rotineiramente na literatura. Os resultados permitiram concluir que as compensações dentárias, frequentemente observadas na literatura para a região de incisivos, se estendem também à angulação dos caninos, principalmente no que se refere ao arco inferior.

No intuito de aprimorar o diagnóstico clínico e, consequentemente, o planejamento ortodôntico, Capelozza Filho (2004) propôs um novo conceito em diagnóstico ortodôntico, o conceito de padrão facial. Segundo o autor, a análise facial morfológica individual é a chave para a classificação de cada paciente dentro de um conjunto de características faciais denominado de padrão facial, resultado da determinação genética herdada, responsável pela manutenção da configuração facial ao longo do crescimento. São cinco os padrões faciais estabelecidos pelo autor, cada um possuindo características próprias referentes à morfologia facial, e que se apresentam de forma semelhante dentro de um mesmo padrão, características essas observadas pela sua experiência clínica, num primeiro momento, e confirmadas posteriormente através de pesquisa científica. De uma maneira geral, se enquadram no padrão I aqueles pacientes cujas bases ósseas (maxila e mandíbula) estão bem relacionadas entre si, havendo uma harmonia entre os terços faciais tanto no sentido frontal como no perfil. Aqueles que apresentam discrepância sagital entre as bases ósseas podem ser classificados em padrão II e III. No padrão II, o erro esquelético está relacionado à deficiência de crescimento mandibular ou à protrusão maxilar ou mesmo a somatória dos dois problemas. No padrão III 
ocorre o inverso, a discrepância esquelética pode ter como causa uma mandíbula de tamanho maior (prognatismo mandibular) ou a uma maxila com crescimento deficiente (deficiência maxilar). Há ainda os casos onde o problema não está no plano sagital, mas sim no plano frontal, com discrepância entre os terços faciais. Quando o terço inferior da face encontra-se encurtado, em relação aos terços médio e superior, classifica-se o paciente como padrão face curta e, quando o terço inferior está aumentado ou o terço médio está encurtado classifica-se como face longa. Esse conceito leva em consideração que a configuração facial de cada indivíduo é determinada geneticamente, portanto soberana sob o ponto de vista ortodôntico. O autor também estabeleceu protocolos de tratamento de acordo com cada padrão facial.

As radiografias convencionais e modelos de gesso serviram, e servem até hoje, como os meios pelos quais os métodos de mensuração de inclinação e angulação são empregados, mas o seu uso não se restringe apenas à essa finalidade. Handelman, em 1996, avaliou, por meio da cefalometria, as iatrogenias que ocorreram na região anterior superior e inferior com o tratamento ortodôntico, relacionando-as com o padrão facial de cada paciente. O autor selecionou 107 telerradiografias de indivíduos adultos e mensurou os valores de Sn.GoGn juntamente com a classificação sagital da má-oclusão para agrupamento dos pacientes de acordo com o tipo facial. Os resultados mostraram que os pacientes que obtiveram valores mais baixos para o ângulo Sn.GoGn apresentaram maior quantidade óssea, tanto na região lingual apical dos incisivos inferiores como na região palatina dos incisivos superiores, enquanto que os pacientes com valores mais altos para Sn.GoGn apresentaram uma quantidade de osso mais delgada para os mesmos dentes. Em termos de espessura total do alvéolo mandibular, os valores foram maiores para indivíduos com ângulo Sn.GoGn mais baixos, e o inverso ocorreu para ângulos Sn.GoGn mais altos. Com relação à má-oclusão, a quantidade óssea foi maior na região apical palatina e lingual dos incisivos superiores e inferiores, respectivamente, nas más-oclusões de classe III e menor na região apical lingual 
dos incisivos inferiores nas classe II. Assim o autor concluiu que o limite da movimentação ortodôntica deve respeitar o limite das corticais ósseas, em especial no arco inferior pelo estreitamento daquelas em relação ás raízes dentárias.

Outra ferramenta que veio auxiliar a Ortodontia foi a informática. Surgindo por volta da década de 1980, possibilitou inúmeras mudanças nos métodos de avaliação radiográfica na década seguinte, facilitando o traçado cefalométrico e panorâmico e simulando, de modo virtual, o resultado final do tratamento ortodôntico. Embora o uso de radiografias convencionais possa ser adequado em várias situações clínicas, elas são imagens bidimensionais que apresentam limitações como sobreposição de estruturas anatômicas e distorções e, portanto, prejudicam sua qualidade. Hoje em dia, as imagens multiplanares geradas pela tomografia computadorizada facilitaram a avaliação radiográfica por permitirem a reconstrução de áreas anatômicas nas três dimensões do espaço e por trazerem informações sobre textura, forma e tamanho, sendo um importante instrumento auxiliar de diagnóstico em todas as áreas da odontologia (Scarfe, Farman e Sukovic 2006).

Em se tratando ainda dos avanços nos métodos de diagnóstico por imagem, têm-se outros recursos disponíveis muito utilizados nas diversas especialidades médicas tais como a ressonância magnética, o ultrassom, a cintilografia, a medicina nuclear, o pet scan (tomografia por emissão de pósitrons) etc...

\subsection{LITERATURAS RELACIONADAS AOS PRINCÍPIOS DA TOMOGRAFIA COMPUTADORIZADA}

A tomografia computadorizada tem sua aplicabilidade voltada para a avaliação e o diagnóstico por imagem dos componentes ósseos e estruturas dentárias através da representação digital da anatomia do paciente, fornecendo uma visão tridimensional em alta resolução das estruturas examinadas (Cohnen 2002 e Tsiklaskis 2005). 
O conhecimento teórico para reconstrução de imagens tomográficas, segundo Sukovic (2003), surgiu em 1917 quando Radon estabeleceu que um objeto tridimensional pode ser reconstruído a partir de uma série infinita de projeções bidimensionais obtidas através de vários ângulos de um mesmo objeto. O primeiro tomógrafo foi desenvolvido em 1967 por um engenheiro, Sir Godfrey N. Hounsfield. Desde então, a tecnologia avançou rapidamente através da criação de quatro gerações de tomógrafos. A primeira geração usava um único elemento detector para a captura dos feixes de raios-x emitidos de forma linear. Hoje, porém, os avanços recentes possibilitaram o desenvolvimento de múltiplos detectores (16 fileiras de detectores) e escaneamento em espiral (helicoidal), o que permite a obtenção de vários cortes transversais simultaneamente, reduzindo o tempo em que o exame efetivamente é realizado.

Os tomógrafos de última geração são chamados de Cone Beam ou Tomógrafos de Feixe Cônico pelo fato de emitirem os raios-x em um feixe com formato de um cone. Os aparelhos são constituídos de uma fonte de raios-x e de um detector, fixados em uma haste giratória. Durante um único giro da haste, o detector capta o fluxo de raios-X que passa através da cabeça do paciente realizando o escaneamento de toda a área desejada para a avaliação, diferentemente dos tomógrafos convencionais cujos cortes múltiplos devem ser “empilhados" para se obter uma imagem completa (Sukovic 2003).

Com os avanços tecnológicos, desenvolveu-se uma nova geração de tomógrafos especialmente para a avaliação da região maxilo-facial (Firoosnia et al 1992). É o caso dos tomógrafos de feixe cônico, como o I-Cat, os quais permitem a obtenção de imagens semelhantes às obtidas nos centros médicos, porém com baixa dose de radiação, fácil manuseio, tempo de exame reduzido e excelente qualidade de imagem (Mah et al 2003). Uma grande vantagem desse método de avaliação é que, com apenas um exame, podem-se fazer reconstruções nos mais variados planos e obter múltiplos cortes de imagens como as telerradiografias, panorâmicas, oclusais, transaxiais e coronais (Capelozza Filho et al 2005). 
Segundo Scarfe et al (2006), a tomografia computadorizada de feixe cônico permite a criação, em tempo real, de imagens não apenas no plano axial, mas também bidimensionais nos planos coronal, sagital e até mesmo imagens oblíquas ou curvas.

Por fornecer imagens com grande riqueza de detalhes, a tomografia vem sendo utilizada na odontologia para a localização de dentes impactados, cistos, tumores, processos inflamatórios, e mais recentemente, na implantodontia e no acompanhamento radiológico para planejamento pré e pós-cirúrgico dos pacientes com fissuras de lábio e palato, os quais necessitam da realização do enxerto ósseo para a reconstrução do defeito alveolar (Schulze et al 2004). Auxiliam também a Ortodontia no diagnóstico e planejamento ortodôntico de dentes impactados, em casos com necessidade de ancoragens adicionais, como míniimplantes, e no acompanhamento do efeito da movimentação ortodôntica no osso alveolar durante o tratamento e no pós-tratamento, surgindo assim uma nova possibilidade de metodologia para a avaliação das inclinações e angulações, com representação fiel das estruturas dentárias (Capelozza Filho et al 2005).

Com o intuito de informar os profissionais da área odontológica, Garib et al (2007) publicaram um artigo a respeito da aplicação da tomografia no diagnóstico clínico, na aquisição de imagem e interpretação do exame tomográfico, fazendo distinção entre a tomografia tradicional e a de feixe cônico. Segundo os autores, tanto a tomografia tradicional como a de feixe cônico podem ser utilizadas para a região dento-maxilo-facial, entretanto a única característica que possuem em comum seria a radiação. A imagens são geradas na forma tridimensional e cada ponto da imagem é chamado de voxel. Denomina-se voxel a menor unidade da imagem na espessura do corte, podendo o mesmo variar de 0,5 a $20 \mathrm{~mm}$, a depender da região do corpo a ser escaneada e da qualidade da imagem desejada. Na tomografia tradicional, a fonte de raios-x emite feixes em forme de leque e os sinais são captados pelos receptores. O tubo de raios-x gira $360^{\circ}$ ao redor da cabeça do paciente, o tanto 
de vezes necessário para a obtenção dos cortes axiais para posterior reconstrução da imagem. Cada giro dura em média um segundo, multiplicado pelo número de cortes a serem obtidos. Enquanto o exame é realizado, a dose de radiação é ininterrupta, portanto considerada alta. Após a realização dos cortes, a imagem é reconstruída de forma tridimensional ou em vários planos, apresentando boa nitidez e ótimo contraste. Entretanto, na presença de materiais metálico, ocorre a geração de muitos artefatos prejudicando a qualidade do exame. Nos aparelhos mais modernos, a mesa na qual o paciente fica posicionado movimenta-se junto com a rotação do tubo de raios-x, determinando uma trajetória helicoidal, da qual provém o nome do aparelho: tomografia computadorizada helicoidal. A grande vantagem desses aparelhos de última geração refere-se à velocidade na aquisição da imagem quando o movimento do paciente constitui um fator limitante ao exame.

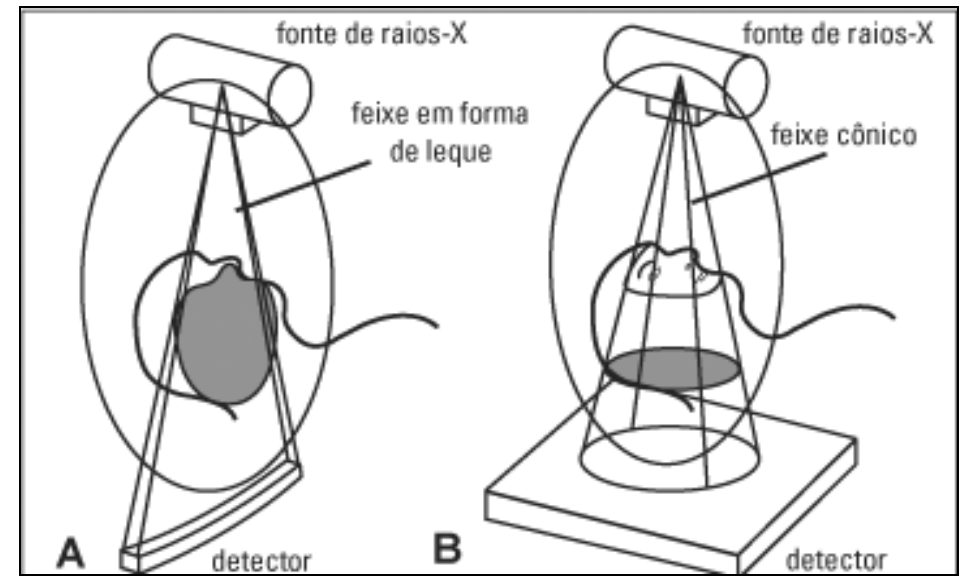

Figura 7 - Feixe de raios $\mathrm{X}$ tradicional (A) e feixe cônico (B).

Na tomografia computadorizada de feixe cônico, os aparelhos são mais compactos e, portanto, permitem apenas o escaneamento das regiões da cabeça e pescoço. A fonte de raiosx emite um feixe em forma de cone, fazendo com que o tubo de raios-x gire $360^{\circ}$ uma única vez ao redor da cabeça do paciente. O tempo de duração do exame varia de 10 a 70 segundos e nesse período, a dose de radiação emitida varia de 3 a 6 segundos. Comparando este 
aparelho à tomografia convencional, observa-se que a dose de radiação é aproximadamente 15 vezes menor. Além disso, permitem não só a reconstrução tridimensional ou multiplanar, mas também reconstruções radiográficas bidimensionais convencionais. Assim como a tomografia tradicional, este exame apresenta boa nitidez, porém baixo contraste entre tecido duro e mole e, na presença de peças metálicas, ocorre pouca produção de artefato em comparação ao método convencional.

Inúmeras são as possibilidades de aplicação da tomografia computadorizada descritas pelos autores: avaliação do posicionamento tridimensional de dentes retidos e sua relação com os dentes e estruturas vizinhas; avaliação do grau de reabsorção radicular de dentes adjacentes a caninos retidos; visualização das tábuas ósseas vestibular e lingual e sua remodelação após movimentação dentária; avaliação das dimensões transversas das bases apicais e das dimensões das vias aéreas superiores; avaliação da movimentação dentária para a região de osso atrésico (rebordo alveolar pouco espesso na direção vestíbulo-lingual) ou com invaginação do seio maxilar, avaliação de defeitos e enxerto ósseo na região de fissuras lábiopalatais; análise quantitativa e qualitativa do osso alveolar para a colocação de míni-implantes de ancoragem ortodôntica; medições do exato diâmetro mesio-distal de dentes permanentes não irrompidos para a avaliação da discrepância dente-osso na dentadura mista e avaliações cefalométricas. Assim, os autores concluem que as expectativas apontam para uma utilização mais abrangente da tomografia computadorizada de feixe cônico na odontologia e na Ortodontia, resultado de avanços tecnológicos, da redução da exposição à radiação e da ótima qualidade da imagem. Com a definição de novos conhecimentos gerados pela visão tridimensional do crânio e da face, o futuro reserva a renovação de conceitos e paradigmas, assim como a redefinição de metas e planos terapêuticos ortodônticos.

Com o objetivo de avaliar esse novo método de exame, do ponto de vista ortodôntico, Korbmatcher et al (2007) selecionaram 83 imagens tomográficas de dois aparelhos diferentes, 
sendo 68 provenientes do aparelho NewTom e 15 do Ardcadis Orbic 3D, sendo que dois examinadores independentes avaliaram as indicações pelas quais os exames tinham sido indicados e a qualidade da visualização em termos de valores. As imagens foram categorizadas de acordo com um protocolo pré-definido e quantificável. Segundo os autores, os resultados mostraram que, para os pacientes fissurados, tanto a morfologia óssea como a presença de osteointegração dos parafusos e placas foram bem visualizados, e a presença de dentes impactados e terceiros molares justificaram o seu uso, embora os valores tenham sido julgados diferentemente pelos dois examinadores. A tomografia computadorizada não acrescentou mais informações quando comparada à radiografia convencional na avaliação de articulações cartilaginosas. Assim, os autores concluem que, nos casos mais complexos, em que as imagens 3D são mandatórias, o método de escolha é a tomografia computadorizada por feixe cônico. Além do mais, para os pacientes fissurados e para aqueles com tratamento ortodôntico-cirúrgico, esse método fornece mais informações que as radiografias comuns.

Holberg et al (2005) avaliaram a qualidade e acurácia da tomografia computadorizada de feixe cônico para a análise das estruturas dentárias e para a comparação com a tomografia computadorizada convencional (helicoidal) em termos de vantagens e desvantagens no uso clínico. Foram selecionadas 417 imagens tomográficas, sendo 209 realizadas pela tomografia de feixe cônico e 209 pelo método convencional. Para todos os dentes foram avaliados os espaços do ligamento periodontal nos três terços radiculares, tanto em termos de qualidade de reprodução como em definição. Os resultados mostraram que, ao contrário da tomografia computadorizada convencional, o feixe cônico quase não apresentou artefatos ou estes eram bem discretos causando apenas uma disrupção na imagem. A qualidade da imagem dentária e das áreas ósseas foi melhor, em termos gerais, na tomografia convencional pois o espaço do ligamento periodontal foi de difícil visualização no exame feito pelo feixe cônico, e a interface dentina-esmalte e a cavidade pulpar apresentaram imagens com limites mais bem 
definidos na tomografia convencional. Os autores concluíram que a tomografia computadorizada continua sendo o método padrão para a avaliação das raízes dentárias e as estruturas ósseas adjacentes.

A tomografia computadorizada de feixe cônico representa uma inovação, em termos de imagem tomográfica, para o uso na odontologia. Quando comparada às outras tomografias computadorizadas, ela se destaca pela aquisição rápida da imagem com baixa dose de radiação. O I-Cat é um exemplo de aparelho de tomografia de feixe cônico desenvolvido para a região maxilo-facial, principalmente para planejamento cirúrgico e implantodontia. Lascala, Panella e Marques (2004) avaliaram a acurácia das medidas lineares obtidas pelo feixe cônico com o aparelho NewTom. Primeiramente, os autores definiram 13 medidas nos crânios secos interna e externamente e os submeteram ao exame tomográfico. A seguir, os autores mediram as mesmas distâncias anatômicas definidas nos crânios secos, agora nas imagens tomográficas. Segundo os autores, os resultados mostraram que as medidas reais foram sempre maiores que aquelas obtidas pela tomografia computadorizada, mas estatisticamente significantes apenas para as medidas cranianas internas. Assim concluem que, embora os resultados tenham mostrado medidas menores nas imagens tomográficas, elas foram, estatisticamente significantes apenas para a base interna do crânio, constituindo um método bastante confiável para a avaliação de medidas lineares de outras estruturas mais próximas, associadas ao complexo dento-maxilo-facial.

O desenvolvimento dos tomógrafos para uso na odontologia permitiu, pela primeira vez na história da Ortodontia, o acompanhamento do efeito do tratamento no osso alveolar, a relação de cada raiz dentária com a tábua óssea que a sustenta e a mensuração das inclinações e angulações dentárias impostas pelo tratamento ortodôntico em cada dente individualmente, algo de extrema relevância clínica no sucesso do tratamento, a longo prazo, e impossível de 
ser realizado até então pelas limitações na qualidade da imagem, sobreposição das estruturas anatômicas e distorção que apresentam as radiografias convencionais.

Sabendo das distorções que ocorrem nas radiografias convencionais, Peck et al (2007) realizaram um estudo comparando dois métodos de aquisição de imagens para a avaliação da angulação dentária por meio da radiografia panorâmica e da tomografia computadorizada de feixe cônico. Os autores utilizaram modelos de gesso de cinco pacientes e realizaram radiografia panorâmica e tomografia computadorizada de cada paciente. A seguir, três indivíduos compararam as angulações dentárias obtidas nos dois tipos de imagem, com resultados bastante confiáveis. Os resultados foram submetidos ao teste estatístico com comparação padrão-ouro, mostrando que a tomografia computadorizada produziu medidas muito precisas da angulação dentária, enquanto que a panorâmica não forneceu um resultado confiável nesses mesmos termos.

\subsection{LITERATURAS RELACIONADAS ÀS CARACTERÍSTICAS FACIAIS E DENTÁRIAS DOS PACIENTES COM FISSURA LABIOPALATINA BILATERAL COMPLETA}

A fissura transforame incisivo bilateral rompe a maxila em três segmentos: dois segmentos palatinos posteriores e a pré-maxila (expressão embrionária do palato primário), tendo influência direta no padrão facial bem como no contorno e dimensões da arcada dentária superior (Fig 8). A pré-maxila encontra-se projetada anterior e superiormente e lateralizada, enquanto que os segmentos palatinos posteriores, distanciados ao nascimento, aproximam-se e rotacionam para medial durante o crescimento (Trindade e Silva Filho 2007, p.173-98). 


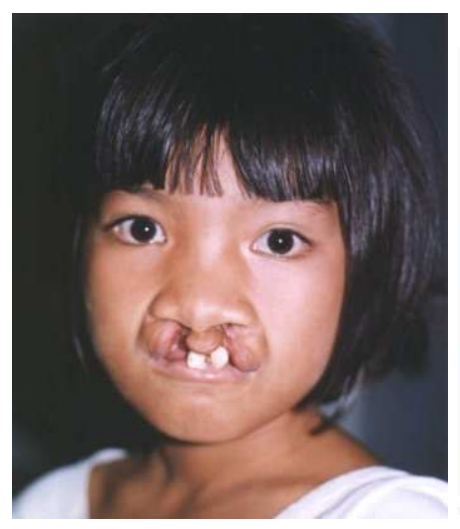

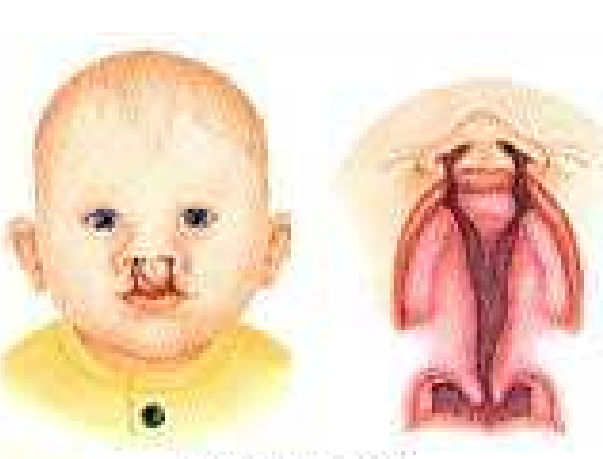

BILATERAL

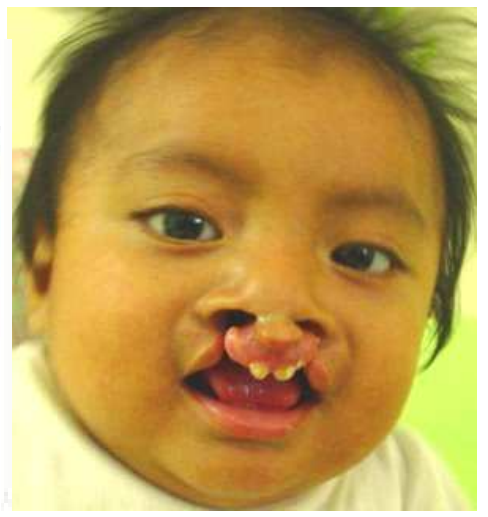

Figura 8 - Exemplos de fissura lábio-palatina bilateral completa.

As transformações impostas pela fissura na face média e a influência das cirurgias primárias, em especial a queiloplastia, agridem diretamente a estética facial (Silva Filho et al 1998). As cirurgias primárias têm seu efeito predominante no retroposicionamento da prémaxila, algo considerado positivo num primeiro momento, mas que, ao longo do crescimento, causam restrição no desenvolvimento transversal e sagital da maxila, levando a um perfil facial côncavo e a importantes alterações intrabucais como inclinação lingual dos incisivos superiores e mordida cruzada anterior e posterior bilateral, com diferentes graus de comprometimento para cada paciente. É muito comum a esses pacientes agenesias dentárias, sendo o incisivo lateral, envolvido na fissura o mais frequentemente ausente, presença de supranumerários adjacentes à fissura e outras alterações morfológicas e na fala, tornando o tratamento complexo e interdisciplinar (Silva Filho et al 2003)

O perfil facial mantém-se convexo na infância, aproximando-se dos valores normais na adolescência e, frequentemente, tornando-se menor que o normal na idade adulta. Devido à influência das cirurgias primárias no crescimento facial e dentoalveolar, esses pacientes apresentam um perfil facial e posicionamento dentário característicos do padrão III (Capelozza Filho 2004). O grau de comprometimento facial varia de paciente para paciente, pois, além da atuação das cirurgias primárias, lida-se com características de crescimento individuais e extensão das fissuras, sendo mais marcantes nos pacientes com fissura bilateral 
(Geraedts et al 2007 e Silva Filho et al 1998). Muitas vezes, a correção ortognática se faz necessária juntamente com o tratamento ortodôntico para devolvê-los, características faciais e intrabucais próximas da normalidade.

Um protocolo bastante comum aos pacientes com fissuras envolvendo o rebordo alveolar é a movimentação mesial do canino permanente e dos dentes posteriores, após a realização do enxerto ósseo alveolar, para ocupar o espaço deixado pela ausência do incisivo lateral. Além do fechamento do espaço sem a necessidade de colocação de implantes ou próteses fixas/móveis, esse protocolo permite a estimulação do osso enxertado para não ocorrer reabsorção. Silva Filho et al (2006) publicaram um artigo ilustrando a possibilidade de se trocar o canino pelo primeiro pré-molar num tratamento ortodôntico conduzido com extração de dentes. Essa situação, que enfrenta resistência por parte de ambos, ortodontistas e pacientes, elimina o dente canino sem, no entanto, eliminar a função da cúspide canina na desoclusão lateral, isolada ou em grupo, o que sela a harmonia com os conceitos funcionais da escola gnatológica. Para os autores, a extração do canino permanente suscita indignação de muitos ortodontistas ortodoxos, cuja opinião oscila da ambivalência à condenação radical, devido principalmente à crença do perverso déficit funcional resultante, mas também atrelada à preocupação do efeito estético no sorriso. Esta última, sim, preocupação maior do leigo, que vê a Ortodontia principalmente como um exercício estético. Sem trair as convicções, certamente legítimas, os objetivos oclusais de um tratamento ortodôntico visam a conciliar estética, função e saúde periodontal, com ou sem caninos.

Segundo Mussing et al (2005), os pacientes com fissura de lábio e palato frequentemente apresentam dentição atípica, variações na área da fissura, incisivo lateral dismórfico, agenesias congênitas, supranumerários e caninos impactados após enxerto ósseo alveolar. Esses achados, típicos em pacientes fissurados são importantes para determinar a necessidade e a época ideal para a realização do enxerto ósseo alveolar, a fim de se avaliar a 
morfologia e o prognóstico dos dentes na área da fissura e, também, para o planejamento do tratamento ortodôntico. A tomografia computadorizada pode ser bastante útil nesses casos.

Ainda no ano de 2005, dois pesquisadores do Hospital de Reabilitação de Anomalias Craniofaciais, Lauris e Ferrari Junior, realizaram paralelamente duas dissertações de mestrado avaliando os efeitos das cirurgias primárias de lábio e palato na estética facial dos pacientes com fissura transforame incisivo bilateral. Em seu trabalho, Lauris (2005) selecionou 30 pacientes com idades entre 5 e 10 anos, sendo 24 do gênero masculino e 6 do gênero feminino, com o objetivo de avaliar, por meio de fotografias de perfil e um questionário específico, a estética facial de indivíduos com fissura transforame incisivo, operados segundo o protocolo do HRAC-USP. O grupo de examinadores foi composto por 5 ortodontistas do HRAC-USP, 5 ortodontistas não relacionados à área de fissura, 5 cirurgiões plásticos do HRAC-USP, 5 cirurgiões plásticos não relacionados à área de fissura e 5 leigos com formação superior. Tais examinadores deveriam classificar a agradabilidade facial em uma escala de $1 \mathrm{a}$ 9, sendo 1 a pior classificação e 9 a melhor para cada estrutura julgada. Os escores atribuídos foram comparados estatisticamente e, como resultado, Lauris observou que o grupo composto por ortodontistas do HRAC atribuiu uma mediana de 7 (aparência esteticamente agradável) e o grupo de cirurgiões plásticos do HRAC atribuiu 5 (aparência esteticamente aceitável). Já o grupo composto por leigos atribuiu um valor mediano de 4 (aparência esteticamente aceitável), enquanto que os grupos compostos por ortodontistas e cirurgiões plásticos não relacionados à área de fissura atribuíram o valor mais baixo, 3 (esteticamente desagradável). A autora também observou diferenças estatisticamente significantes entre todos os grupos, exceto para aqueles grupos compostos por profissionais da saúde não relacionados à área de fissura. Segundo Lauris, foram classificados como desagradáveis, esteticamente, o nariz, o terço médio da face e o lábio superior. Para a autora, as diferenças observadas entre os grupos advieram da interação do examinador com a estética e o conhecimento das características 
intrínsecas que o crescimento imprime na face do paciente com a deformidade, o que difere do normal. Os profissionais não relacionados à área da fissura possuem como comparativo os parâmetros de normalidade e, por isso, exigiram mais da estética dos pacientes da amostra. Já os profissionais experientes em fissura, sabendo da frequência de resultados aquém da normalidade, foram mais complacentes na atribuição dos escores, e os leigos, teoricamente desprovidos de conhecimento técnico específico, situaram-se na faixa intermediária e, provavelmente, representam a avaliação mais próxima da sociedade onde o paciente está inserido.

Ferrari Junior (2005), assim como Lauris, propôs-se a avaliar a estética facial de indivíduos com fissura transforame incisivo bilateral submetidos ao protocolo reabilitador do HRAC-USP. Para tanto, selecionou 23 pacientes adultos com fissura bilateral completa de ambos os gêneros, reabilitados no HRAC. O grupo de examinadores foi composto por 5 cirurgiões plásticos e 5 ortodontistas relacionados à área da fissura, 5 cirurgiões plásticos e 5 ortodontistas não relacionados à área da fissura e 5 leigos. A metodologia empregada na avaliação foi a mesma de Lauris com fotografias faciais de perfil para a atribuição de escores de 1 a 9. Segundo o autor, quase todos os pacientes avaliados foram classificados como apresentando um perfil esteticamente aceitável. Nenhum paciente foi considerado como esteticamente desagradável por ortodontistas e cirurgiões plásticos do HRAC, os quais atribuíram os maiores valores aos perfis faciais, seguidos por examinadores leigos, por cirurgiões plásticos e, finalmente, por ortodontistas não vinculados à fissura. As estruturas mais citadas como responsáveis pelo comprometimento estético nos pacientes foram o nariz, o terço médio e o lábio superior, assim como em Lauris (2005). 



\section{PROPOSIÇÃO}





\section{PROPOSIÇÃO}

Este estudo tem como objetivos:

1- Avaliar qualitativamente uma metodologia que se baseia no uso de imagens tomográficas para mensuração das inclinações coronárias e angulações dentárias;

2 - Avaliar quantitativamente os valores encontrados para a angulação dentária e a inclinação coronária dos dentes anteriores nos arcos dentários, superior e inferior, e compará-los à literatura pertinente;

3 - Avaliar a morfologia das estruturas ósseas e dentárias e de suas relações entre si nesse exame tomográfico realizado. 




\section{MATERIAL E MÉTODOS}

\subsection{SELEÇÃO DA AMOSTRA}

Para a realização do estudo proposto, foram selecionados de modo aleatório dez pacientes do Hospital de Reabilitação de Anomalias Craniofaciais da USP /Bauru (HRAC) com fissura lábio-palatina bilateral completa.

\subsubsection{Critérios de inclusão e exclusão}

Para compor a amostra, cada paciente foi submetido a um exame intrabucal prévio com espelho clínico n.5 no setor de Ortodontia do HRAC, observando-se apenas a finalização ortodôntica satisfatória com engrenamento dentário, boa relação inter e intra-arcos, estética adequada, independentemente do gênero ou idade. Mesmo nos casos onde o planejamento ortodôntico incluiu a finalização do tratamento com próteses ou implantes, e estes ainda não haviam sido realizados, considerou-se o paciente incluído na amostra pela oportunidade de realização do exame tomográfico, uma vez que o objetivo foi avaliar apenas os dentes e não os elementos protéticos, e o tratamento ortodôntico havia sido bem conduzido. Todos os pacientes haviam recebido tratamento ortodôntico no Setor de Ortodontia do HRAC e estavam em fase de controle pós-tratamento, quando é pedida uma documentação radiográfica de rotina (panorâmica, telerradiografia em norma lateral e periapicais). De modo a não expor o paciente à radiação desnecessária, as radiografias convencionais supracitadas foram substituídas pelo exame tomográfico, nesta amostra.

Optou-se pela seleção de um grupo pequeno $(n=10)$ para a avaliação por se desconhecer a precisão e a reprodutibilidade do método a ser empregado, uma vez que há poucos trabalhos publicados nesta linha de pesquisa. Além disso, há uma vasta literatura 
avaliando a inclinação e a angulação dos dentes por meio de radiografias bidimensionais (panorâmica e telerradiografia) e modelos de gesso ao término do tratamento ortodôntico, o qual serviu como parâmetro de comparação dos resultados e da avaliação da eficiência do método.

Para a realização das medidas, os dentes que, porventura, se apresentavam reabilitados com coroas protéticas foram descartados, uma vez que essas próteses foram confeccionadas após o tratamento ortodôntico, alterando a anatomia da face vestibular e podendo prejudicar a correta localização do ponto EV.

\subsection{CARACTERÍSTICAS DA AMOSTRA}

Para melhor compreensão dos resultados, algumas considerações devem ser feitas com relação aos pacientes da amostra:

- Dos dez pacientes avaliados, três foram tratados com cirurgia ortognática associada ao tratamento ortodôntico e o restante com tratamento ortodôntico compensatório. Dentre os pacientes operados, dois eram de etnia branca e um era indígena;

- O paciente de etnia indígena apresentava protrusão inferior;

- Em quatro casos, os primeiros pré-molares ocupavam a posição de caninos e os caninos estavam no lugar dos incisivos laterais;

- Em três casos havia ausência do dente 12 e 22, com espaço protético reservado para futura reabilitação com implante ou próteses;

- Em dois casos os incisivos laterais eram dentes mal-formados, possivelmente conóides ou pré-caninos com coroas protéticas, e foram excluídos da avaliação;

- Um dos pacientes possuía ausência do canino esquerdo e o espaço foi mantido para reabilitação protética; 
- Um dos pacientes apresentava coroa protética no incisivo superior direito e este dente foi excluído da avaliação;

- Em um dos pacientes não foi realizada cirurgia de enxerto ósseo alveolar secundário;

- No arco inferior, apenas um paciente apresentou ausência de um incisivo central inferior com tratamento ortodôntico corretivo e ausência de espaço para este dente.

\subsection{EXAME TOMOGRÁFICO}

As imagens tomográficas foram realizadas no setor de radiologia da Faculdade de Odontologia de Bauru FOB/USP, utilizando o Tomógrafo Computadorizado de feixe Cônico, I-Cat (Imaging Science International,Pennsylvania, EUA,) (Fig. 9).

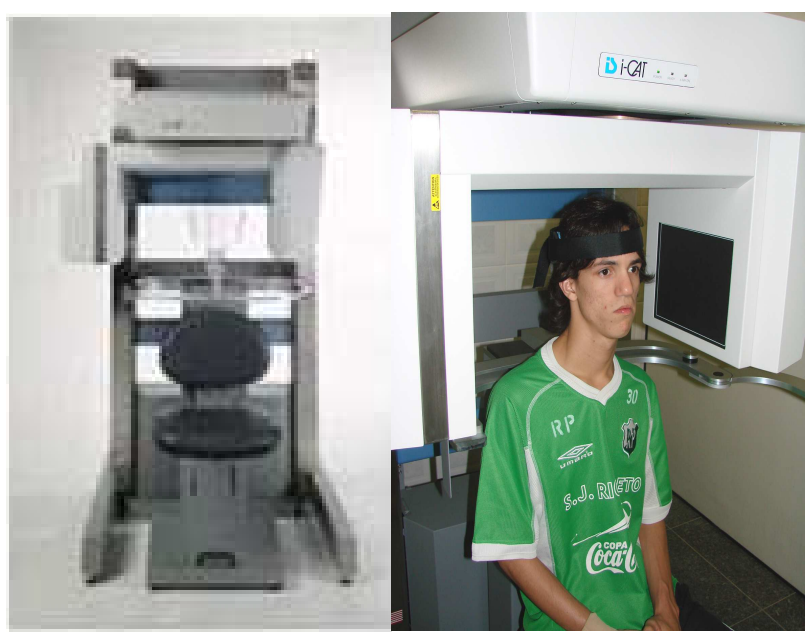

Figura 9 - Tomógrafo I-CAT.

O paciente foi posicionado por um técnico especializado em tomografia computadorizada, seguindo todas as recomendações técnicas para o correto posicionamento da cabeça. O aparelho possui duas linhas guias vermelhas, uma vertical e outra horizontal, que servem como referência para o posicionamento da cabeça (Fig. 10). A linha horizontal deve 
simular o plano oclusal e ficar posicionada entre os lábios, enquanto a linha vertical deve ficar aproximadamente $4 \mathrm{~cm}$ à frente do côndilo.
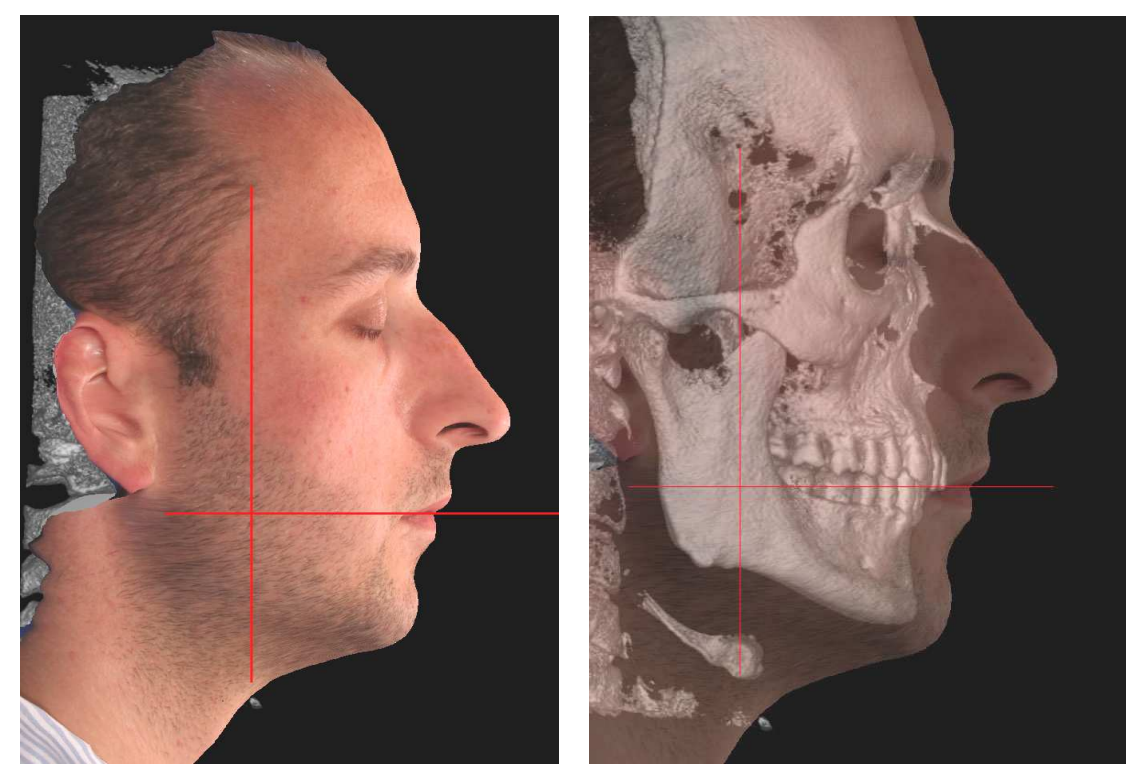

Figura 10 - Linhas guias para o posicionamento da cabeça do paciente.

Após posicionar o paciente, realizou-se um Scout View, um comando para que seja mostrado na tela do computador a área a ser escaneada antes de se iniciar o exame. Este passo é muito importante, pois permite a correção de eventuais erros de posicionamento da cabeça do paciente antes de o exame ser realizado, evitando repetições e radiação desnecessárias.

As imagens foram obtidas utilizando-se o protocolo Extended Height do I-CAT (o qual por conveniência será chamado de crânio estendido) que permite a reconstrução craniofacial tridimensional e gera imagens compatíveis com a telerradiografia em norma lateral, panorâmica e periapical, não prejudicando, portanto, a documentação de rotina desses pacientes. 


\subsection{CARACTERÍSTICAS DO TOMÓGRAFO I-CAT}

O tomógrafo possui colimadores ajustáveis para a seleção de áreas específicas para a avaliação como, por exemplo, somente a maxila ou a mandíbula, ou a aquisição de imagens cranianas totais. Permite, também, a seleção do tempo de exame 10, 20 ou 40 segundos, e a resolução da imagem (tamanho do voxel) que varia de 0,2 a 0,4 voxel. É de se esperar que quanto maiores forem o tempo do exame e a resolução (menor voxel disponível), melhores serão as imagens obtidas e a nitidez dos detalhes. Exames mais longos, entretanto, são mais sensíveis à alteração de posição da cabeça demora mais para reconstrução das imagens e, o mais importante, aumentam a dose de radiação ao paciente.

Para a aplicação do protocolo crânio estendido, trabalhou-se com uma voltagem de $120 \mathrm{KVp}$ e corrente elétrica de $5 \mathrm{~mA}$. O tempo total do exame foi de 40 segundos, gerando imagens com voxel de 0,4 , sendo que, para esse protocolo, os valores de tempo e resolução de imagem não podem ser alterados e já vêm pré-determinados de fábrica.

Durante a aquisição das imagens, o tubo de raios-x gira $360^{\circ}$ ao redor da cabeça do paciente, em duas etapas, e cada uma tem a duração de 20 segundos, totalizando 40 segundos em que o exame efetivamente é realizado (Fig. 11). Em outras palavras, o tubo de raios-x gira $360^{\circ}$ uma primeira vez, durante 20 segundos, escaneando as partes inferior e média da região craniofacial. Em seguida o braço, onde o tudo de raios-x está apoiado, sobe posicionando-o para escanear a região craniofacial superior e girando novamente $360^{\circ}$ ao redor da cabeça do paciente por outros 20 segundos. 


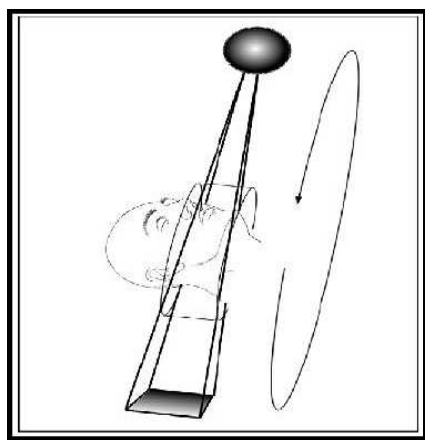

Figura 11 - Método de incidência do feixe de Raios X obtida de Capelozza Filho et al (2005).

Esse protocolo possui um campo de aquisição de imagens chamado de $E F O V$ (Extended Field of View) de $22 \mathrm{~cm}$ de altura por $16 \mathrm{~cm}$ de diâmetro, e o tempo gasto para a reconstrução primária da imagem foi de 2 minutos.

\subsection{SELEÇÃO DAS IMAGENS}

Após a realização do exame tomográfico, as imagens obtidas foram enviadas à Workstation, que acompanha o i-CAT para a reconstrução primária, e então gravadas em um CD para cada paciente, no formato DICOM 3 multi-files.

Para a seleção dos cortes a serem medidos, fez-se a transferência das imagens no formato DICOM 3 multi-files para dois softwares: I-Cat Vision (Imaging Science International, Pensilvania, EUA) e Dolphin Imaging 3D Software (Dolphin Imaging \& Manangement Solutions, Chatsworth, California, USA). As imagens foram trabalhadas no modo 3D do software.

Como esse trabalho propôs-se a avaliar inclinações e angulações dentárias, utilizou-se o software que acompanha o tomógrafo, I-Cat Vision, para a avaliação da inclinação e o software Dolphing Imaging 3D para a avaliação da angulação. A opção por softwares diferentes deu-se pelas seguintes razões: 
(1) O software Dolphing Imaging 3D mostrou-se excelente para auxiliar no posicionamento dos planos tridimensionais e na obtenção da imagem de reconstrução da panorâmica de muito boa qualidade, superior à do I-Cat Vision e, portanto, foi selecionado para a geração das imagens panorâmicas dos pacientes para a medição da angulação dentária.

(2) O software I-Cat Vision apresentou-se superior na execução de todas as etapas para obtenção de um corte do longo eixo do dente, para aferição da inclinação, em relação ao Dolphin Imaging 3D. Isso porque, durante a realização dos testes pilotos com o software Dolphing Imaging 3D, observou-se ser impossível a obtenção do corte exatamente no plano desejado (plano do longo eixo dentário passando pelo ponto EV) sem que houvesse alteração na inclinação do plano oclusal e, consequentemente, na medida da inclinação da coroa dentária, que utiliza esse plano como referência.

\subsubsection{Inclinação}

\subsubsection{Posicionamento dos planos oclusal e plano de Andrews}

$\mathrm{Na}$ tela principal do software I-Cat Vision (fig. 12) aparecem duas imagens craniofaciais frontal e lateral, uma axial e uma reconstrução da panorâmica. Duas linhas paralelas, uma de cor verde representando o plano oclusal e uma de cor vermelha representando o plano de Andrews, aparecem sobre as imagens. Na imagem craniofacial frontal, a cabeça é girada para a correção do plano oclusal (linha verde) e, na imagem craniofacial lateral a cabeça é girada de modo a obter o plano de Andrews (linha vermelha) passando no centro das coroas dos dentes superiores. Esse procedimento não foi repetido para o arco inferior, subentendendo-se que em todo tratamento ortodôntico finalizado os planos de Andrews do arco superior e inferior devem ser paralelos entre si e com o plano oclusal. $\mathrm{Na}$ 
imagem axial determinou-se um arco parabólico (linhas verde e vermelha) contornando os arcos dentários e, a partir dessa imagem, foi gerada a reconstrução da panorâmica.

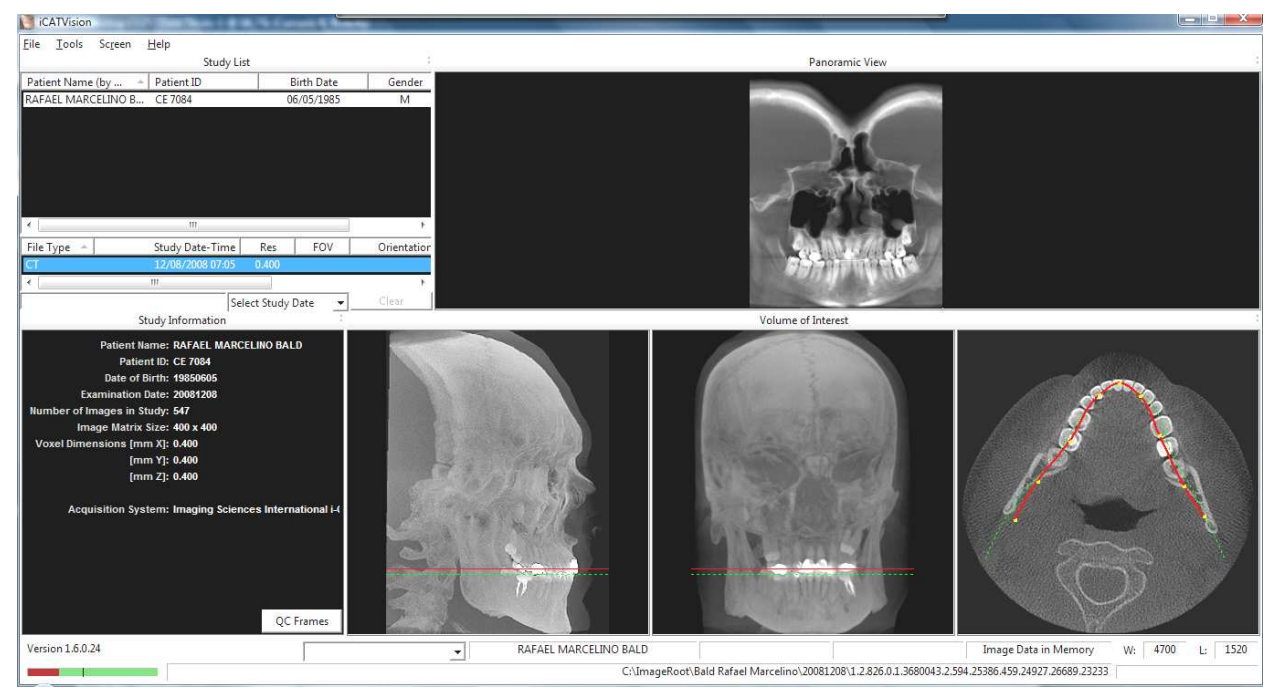

Figura 12 - Etapas para a obtenção dos cortes.

\subsubsection{Obtenção dos cortes}

Para a obtenção das imagens a fim de se mensurar a inclinação das coroas dentárias utilizou-se a opção MPR screen do I-Cat. Nessa tela aparecem três imagens: Axial, Coronal e Sagital (Fig 13).

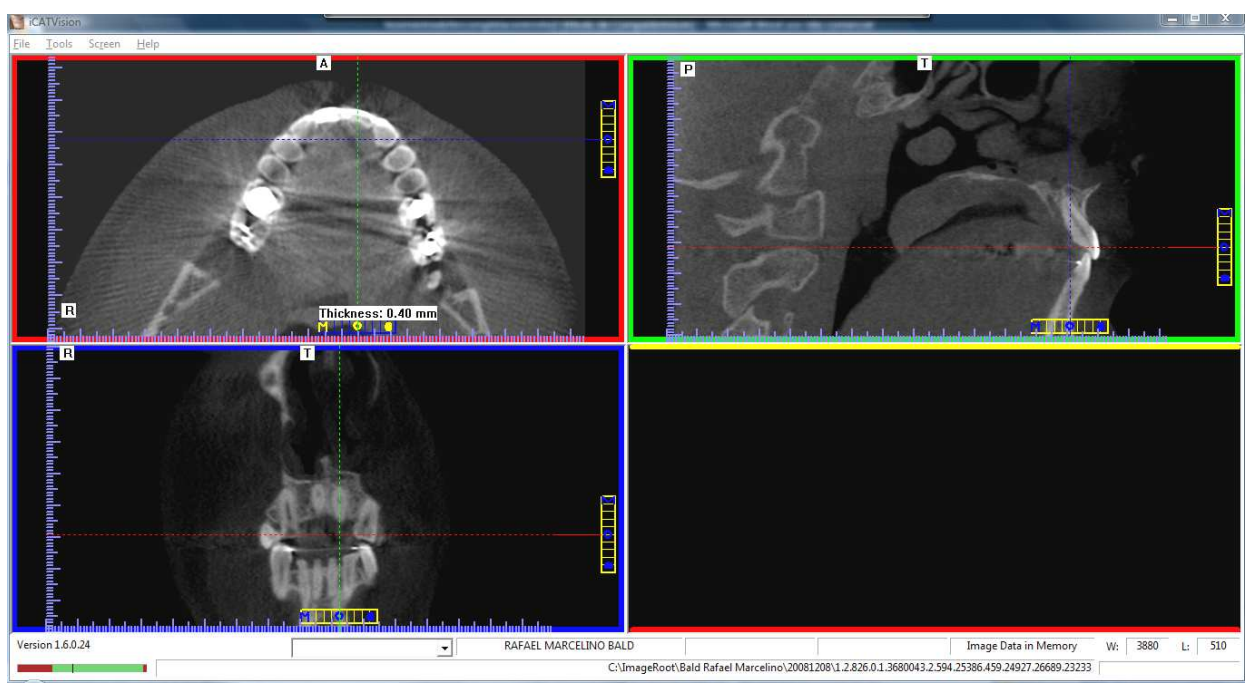

Figura 13 - MPR screen. 
$\mathrm{Na}$ imagem axial (fig. 13 canto superior esquerdo), as linhas verde e azul representaram os corte das imagens geradas nos quadrantes superior direito e inferior esquerdo respectivamente. Cada corte foi realizado com $0,4 \mathrm{~mm}$ de espessura. $\mathrm{Na}$ imagem sagital (fig. 13 canto superior direito), as linhas vermelha e azul representaram as imagens geradas nos outros dois quadrantes superior e inferior esquerdo, respectivamente, com espessura de $0,4 \mathrm{~mm}$. Na imagem coronal (fig. 13 canto inferior esquerdo), as linhas verde e vermelha representaram as imagens geradas nos quadrantes superior esquerdo e direito, respectivamente, com espessura de $0,4 \mathrm{~mm}$.

Após determinar a espessura dos cortes em 0,4mm, para a obtenção do corte do dente exatamente em seu longo eixo passando pelo ponto EV primeiramente, na imagem axial (fig.14 quadrante superior esquerdo) posicionou-se a linha verde passando no centro da coroa clínica. Quando a linha verde não passava sobre o centro da coroa clínica do dente, a imagem axial era girada até que a linha verde ficasse posicionada no centro da coroa clínica. Uma imagem sagital (fig.14 quadrante superior direito) foi gerada a partir da imagem axial. $\mathrm{Na}$ imagem sagital gerada, a linha vermelha foi posicionada passando pelo centro da coroa clínica e a linha azul foi posicionada próxima ao ápice do dente. Uma imagem coronal (fig. 14 quadrante inferior esquerdo) correspondente à posição das linhas verde, vermelha e azul dos quadrantes superiores foi gerada. Nessa imagem, a união das linhas verde e vermelha representaram o ponto EV. Com a ferramenta de linha traçou-se uma linha passando pelo ápice dentário e pela intersecção das retas vermelha e verde. Essa etapa permitiu a geração de uma imagem (fig.14), no quadrante inferior direito, representando o plano parassagital que atravessa o longo eixo dentário exatamente sobre ponto EV e o EVCC. 


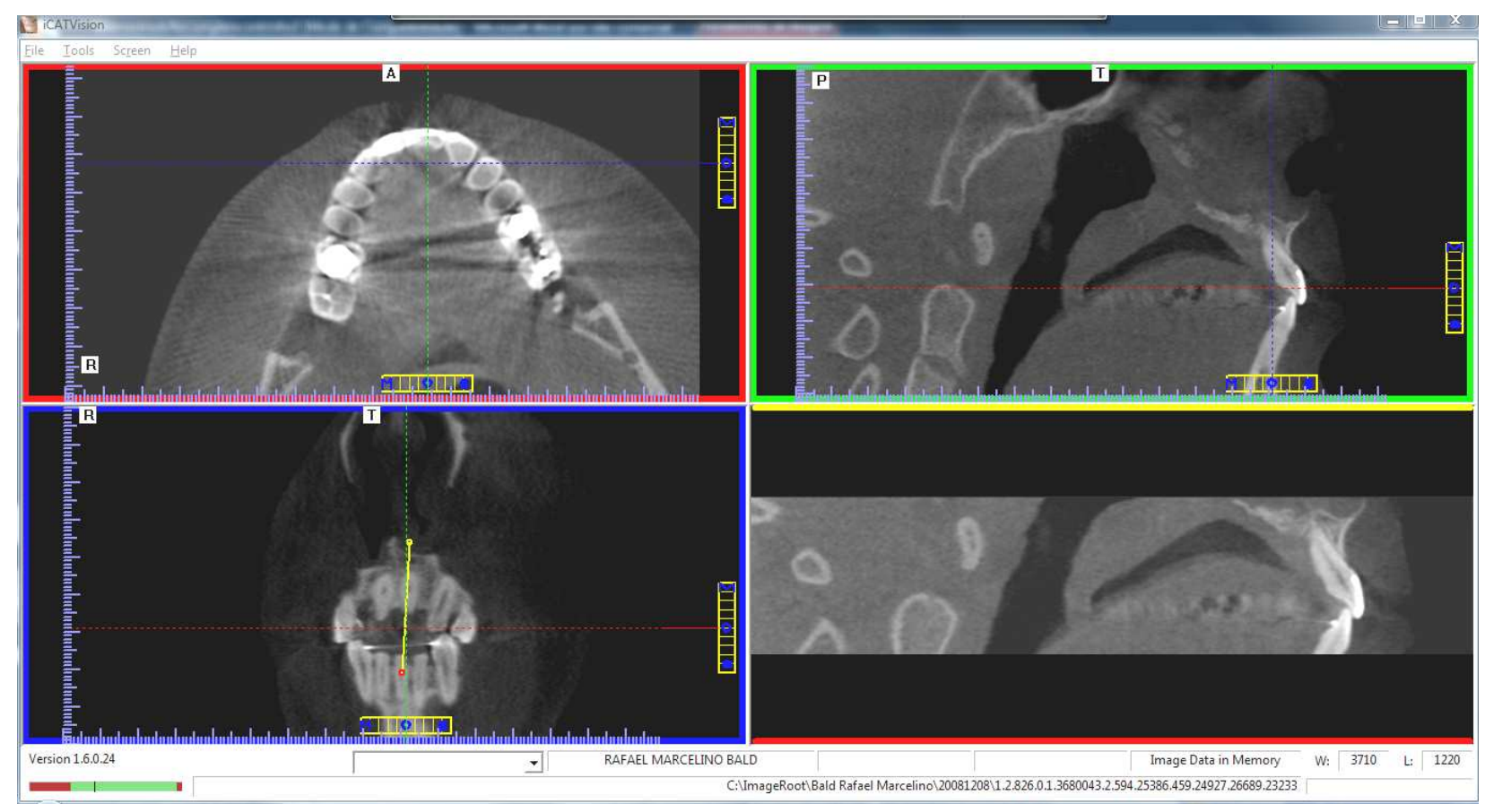

Figura 14 - Corte das imagens.

\subsubsection{Características do corte}

Cada corte apresentou espessura de 0,4 $\mathrm{mm}$ e altura variada, de modo que aparecesse toda a extensão do dente e sua relação com a coroa do dente inferior.

No arco superior (Quadro 6) iniciou-se a seleção dos cortes pelo canino superior direito (dente 13), seguido pelo lateral adjacente (dente 12) quando presente, pelos incisivos centrais direito (11) e esquerdo (dente 21), incisivo lateral esquerdo (dente 22) quando presente e finalizando no canino esquerdo (dente 23). Em alguns casos, os primeiros prémolares realizavam a função de caninos, pois haviam sido movimentados para esta posição, e os caninos para a posição de incisivos laterais na ausência destes. Eles foram considerados respectivamente como caninos e incisivos laterais. Em outros casos, os pré-caninos, bastante comuns na região da fissura, foram transformados em incisivos laterais e assim considerados. 
Quadro 6 - Sequência de seleção dos cortes.

\begin{tabular}{|c|c|c|c|c|c|}
\hline \multicolumn{6}{|c|}{ Arco Superior } \\
\hline \multicolumn{3}{|c|}{ I } & \multicolumn{3}{|c|}{ II } \\
\hline 13 & 12 & 11 & 21 & 22 & 23 \\
\hline 43 & 42 & 41 & 31 & 32 & 33 \\
\hline & $\bar{I}$ & & & I & \\
\hline \multicolumn{6}{|c|}{ Arco Inferior } \\
\hline
\end{tabular}

No arco inferior (Quadro 6), iniciou-se a seleção dos cortes pelo canino esquerdo (dente 33), seguido pelo incisivo lateral e central (dentes 32 e 31 respectivamente), pelos incisivos central (dente 41) e lateral (dente 42), finalizando no canino direito (dente 43). Cada corte foi transferido para o report (relatório) de cada paciente e salvo no formato JPEG (Fig.15), na proporção de 1:1 para ser trabalhado posteriormente em um software de edição de imagem Adobe Photoshop 7.0.1 ${ }^{\circledR}$ (Adobe Systems Incorporated, USA).

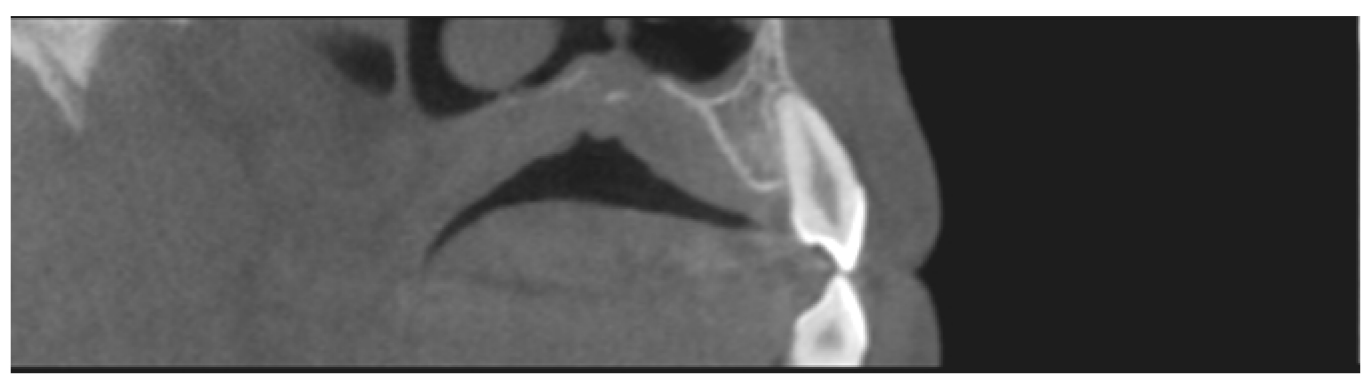

Figura 15 - Exemplo de imagem do dente a ser medido.

\subsubsection{Angulação}

Primeiramente, criou-se uma ficha de dados para cada paciente no ícone new patient e, com auxilio da ferramenta import new DICOM, fez-se a renderização da imagem (reconstrução em 3D) de cada indivíduo da amostra, salvando-a em seguida. A partir de então as imagens ficaram armazenadas no servidor e foram trabalhadas uma a uma. 
Para cada imagem craniofacial reconstruída, foi feita a orientação da cabeça seguindo a padronização descrita abaixo, e todos os cortes seguiram esta orientação:

- na visão frontal (Fig. 17) de acordo com o plano sagital mediano e com o plano de Andrews (superfície ou plano coincidente com o plano médio-transverso de todas as coroas de uma arcada quando os dentes encontram-se bem posicionados);

- na visão lateral direita e esquerda (Fig.16 e 18) de acordo com o plano de Andrews.

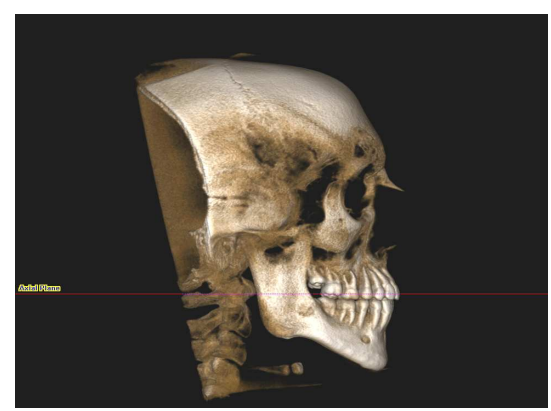

Figura 16 - Plano de Andrews (Visão lado direito).

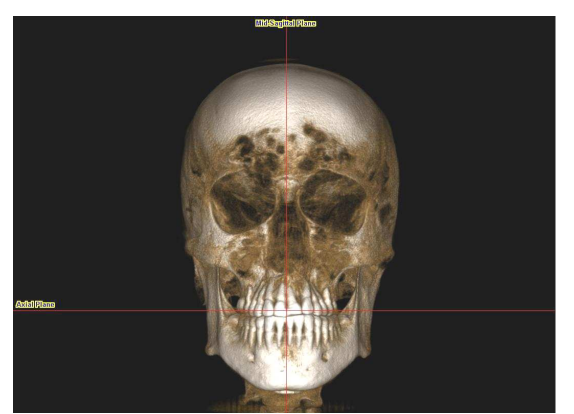

Figura 17 - Planos Sagital Mediano.

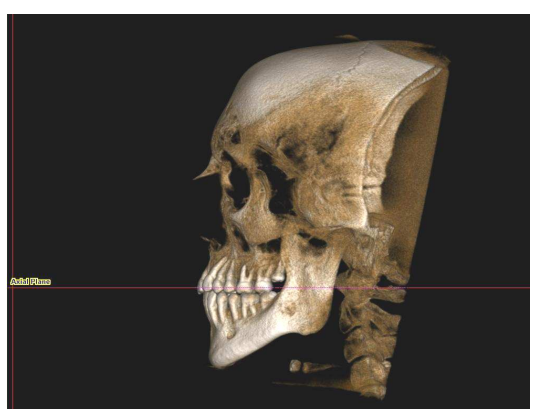

Figura 18 - Plano de Andrews (visão lado esquerdo).

Com a ferramenta Build $x$-Ray pôde-se gerar imagens semelhantes às radiografias convencionais da seguinte maneira: Para a obtenção das imagens, a fim de se aferir a angulação, as seguintes etapas foram realizadas (Fig. 19). A orientação da cabeça pelos planos sagital mediano e plano de Andrews (Fig. 16, 17 e 18) já havia sido estabelecida anteriormente. Então, com a ferramenta Build $x$-Ray, selecionou-se a opção panorâmica. Na visão craniofacial frontal determinou-se a extensão vertical da imagem a ser gerada, exatamente como foi feito para se determinar a inclinação. A linha guia horizontal foi posicionada paralela e coincidente com o plano oclusal dos dentes anteriores para que estas estruturas fossem visualizadas na visão axial. Nessa visão axial determinaram-se as estruturas de interesse a serem visualizadas na panorâmica. Com a ferramenta Redopath, selecionou-se visualizar de região de côndilo do lado direito à região de côndilo do lado esquerdo, passando 
pela oclusal de todos os dentes, descrevendo novamente uma trajetória parabólica semelhante ao formato da arcada dentária.

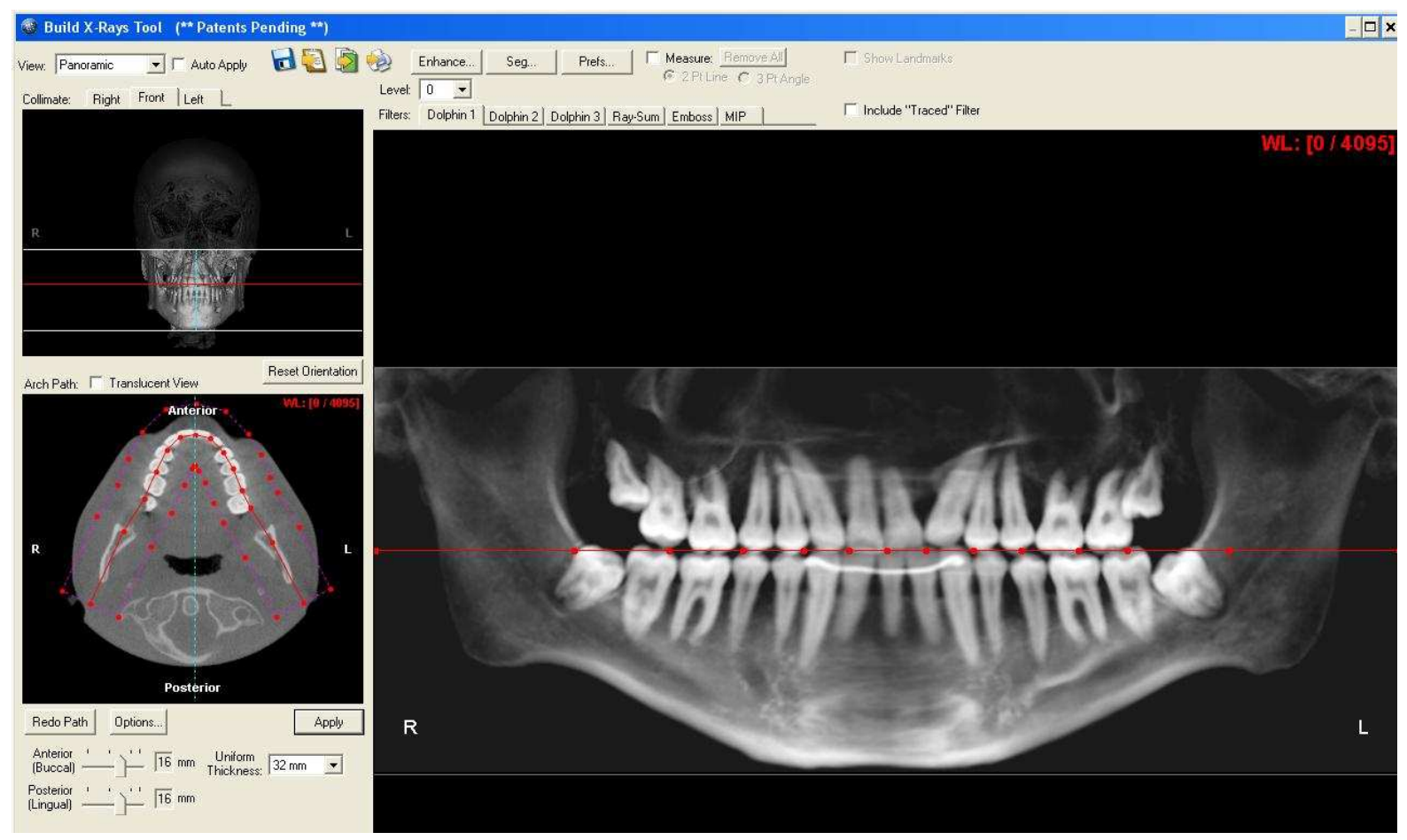

Figura 19 - Etapas para a obtenção da panorâmica para medir a angulação.

\subsubsection{Características do corte}

Padronizou-se a altura da panorâmica delimitada pela borda inferior da mandíbula e limite superior acima dos ápices radiculares, e a espessura em $32 \mathrm{~mm}$. Isso significa que todas as estruturas presentes nessa espessura foram visualizadas, sendo $16 \mathrm{~mm}$ para a região vestibular e $16 \mathrm{~mm}$ para a região lingual, e altura delimitada pela borda inferior da mandíbula e limite superior acima dos ápices radiculares.

Essa imagem foi salva no formato JPEG e, a partir dela, foram medidas as angulações dos dentes anteriores superiores e inferiores (Fig. 20). 


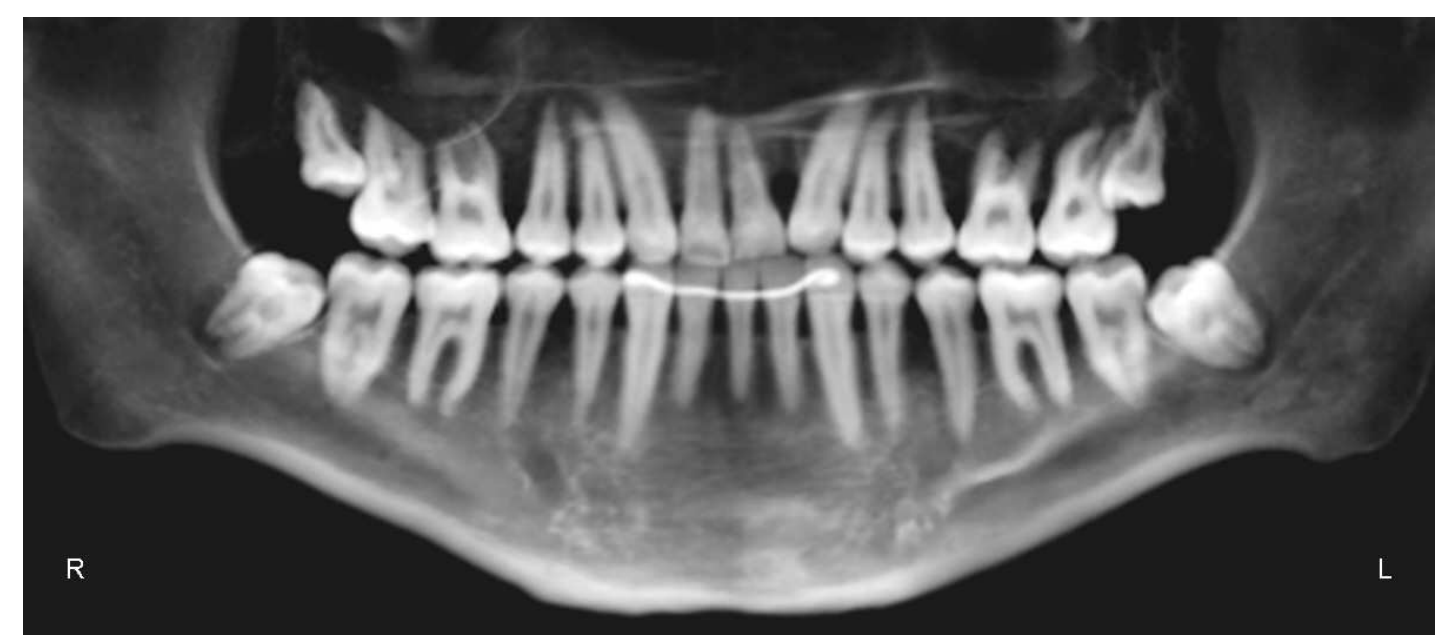

Figura 20 - Panorâmica.

\subsection{AFERIÇÃO DA INCLINAÇÃO}

Concluída a etapa de seleção dos cortes, as imagens foram trabalhadas uma a uma para a mensuração da inclinação e angulação, no software Adobe Photoshop 7.0.1, conforme descrito abaixo. O protocolo descrito a seguir, baseou-se naquele proposto por Andrews (1972) para a medição dos 120 modelos de gesso no estudo das seis chaves da oclusão normal, e segue exatamente o mesmo protocolo descrito por Capelozza Filho, Fattori e Maltagliari (2005).

Primeiro, com a ferramenta de corte, separou-se somente a imagem do dente a ser medido do restante da imagem (Fig. 21).

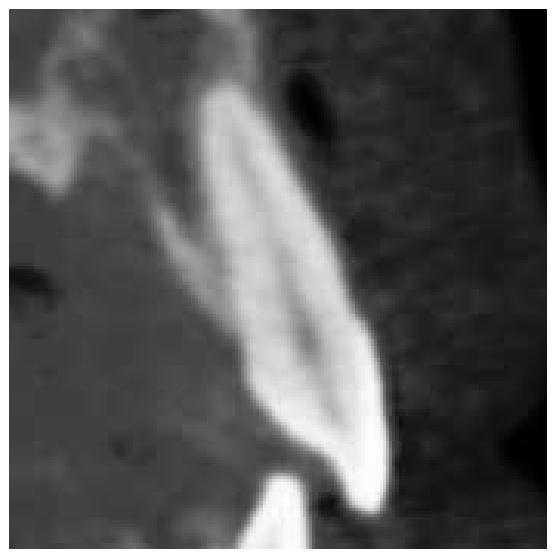

Figura 21 - Corte do incisivo central superior direito. 
Para melhor compreensão da metodologia, será utilizado o seguinte exemplo:

- Coroa Anatômica medindo 9,4 mm;

- Coroa Clínica medindo 7,6 mm;

- Ponto do Eixo Vestibular (Ponto EV) medindo 3,8 mm.

Com o auxilio da ferramenta lápis do software, marcou-se um ponto na porção vestibular da junção amelo-cementária (JAC) e um segundo ponto na borda incisal (ou face oclusal) nos limites entre a face vestibular e borda incisal (ou face oclusal). Com a ferramenta de régua, mediu-se a distância em milímetros entre esses dois pontos, determinando o tamanho da coroa anatômica. Os passos descritos acima podem ser conferidos na figura 22 na qual a coroa anatômica mediu $9,4 \mathrm{~mm}$.
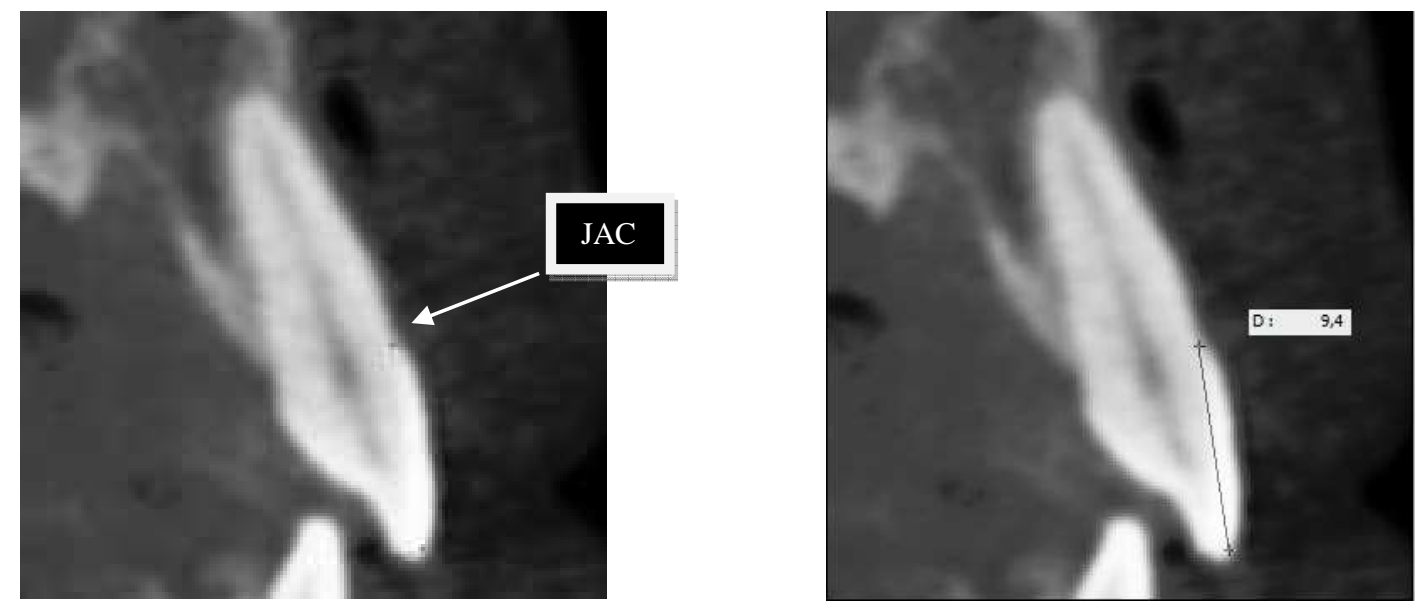

Figura 22 - Coroa Anatômica.

A seguir, para determinar o tamanho da coroa clínica, utilizou-se a ferramenta régua de medida localizada sob o ponto da JAC e, a partir desse ponto, subtraiu-se $1,8 \mathrm{~mm}$ em direção à face vestibular da coroa dentária. Com a ajuda das linhas guias azuis vertical e horizontal foi determinado, na porção cervical da face vestibular do dente, o exato local onde o ponto deveria ser colocado para determinar o limite superior da coroa clínica (Fig.23). Esse ponto foi marcado em azul. Segundo Andrews (1989), coroa clínica é a parte visível do dente 
no final da dentadura mista e na dentadura permanente, com gengiva saudável e sem recessão, e seu limite superior pode ser determinado subtraindo-se $1,8 \mathrm{~mm}$ da coroa anatômica a partir da JAC. Por exemplo, se a coroa anatômica mediu 9,4 mm, subtraiu-se 1,8 mm dessa medida determinando o tamanho da coroa clínica em 7,6 mm (Fig. 23).
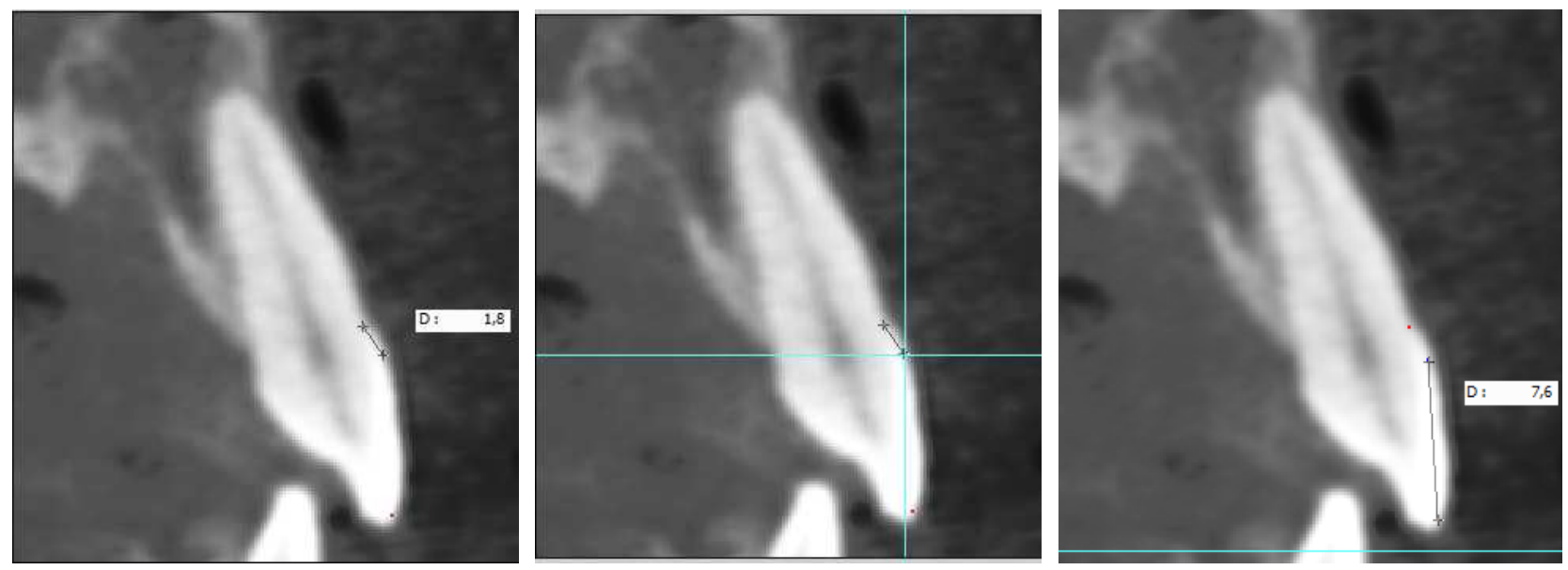

Figura 23 - Coroa Clínica.

Por definição, o Ponto EV (ponto do eixo vestibular da coroa clínica) é um ponto localizado sobre o EVCC (eixo vestibular da coroa clínica) que separa a metade gengival da metade oclusal da coroa clínica. As distâncias entre as extremidades oclusais e gengivais não são iguais para todas as coroas de uma mesma arcada, mas para cada coroa elas são equidistantes (Andrews 1989). Portanto, para determinar a localização do ponto EV, com o auxílio da ferramenta de construção de linha, desenhou-se uma linha guia azul ligando os dois pontos (cervical e oclusal) que representam a extensão da coroa clínica para que a régua de medida ficasse posicionada exatamente sobre esta linha. Assim, se a coroa clínica mediu, por exemplo, 7,6 mm, o ponto EV deveria ser posicionado na metade dessa distância, ou seja, a 3,8 mm equidistante das metades oclusal e gengival. Para tanto, a régua de medida foi posicionada na metade da linha azul e com o auxílio da ferramenta de angulação na própria 
régua, traçou-se uma perpendicular a esta linha até tocar a face vestibular do dente, determinando a localização do ponto EV (Fig 24).
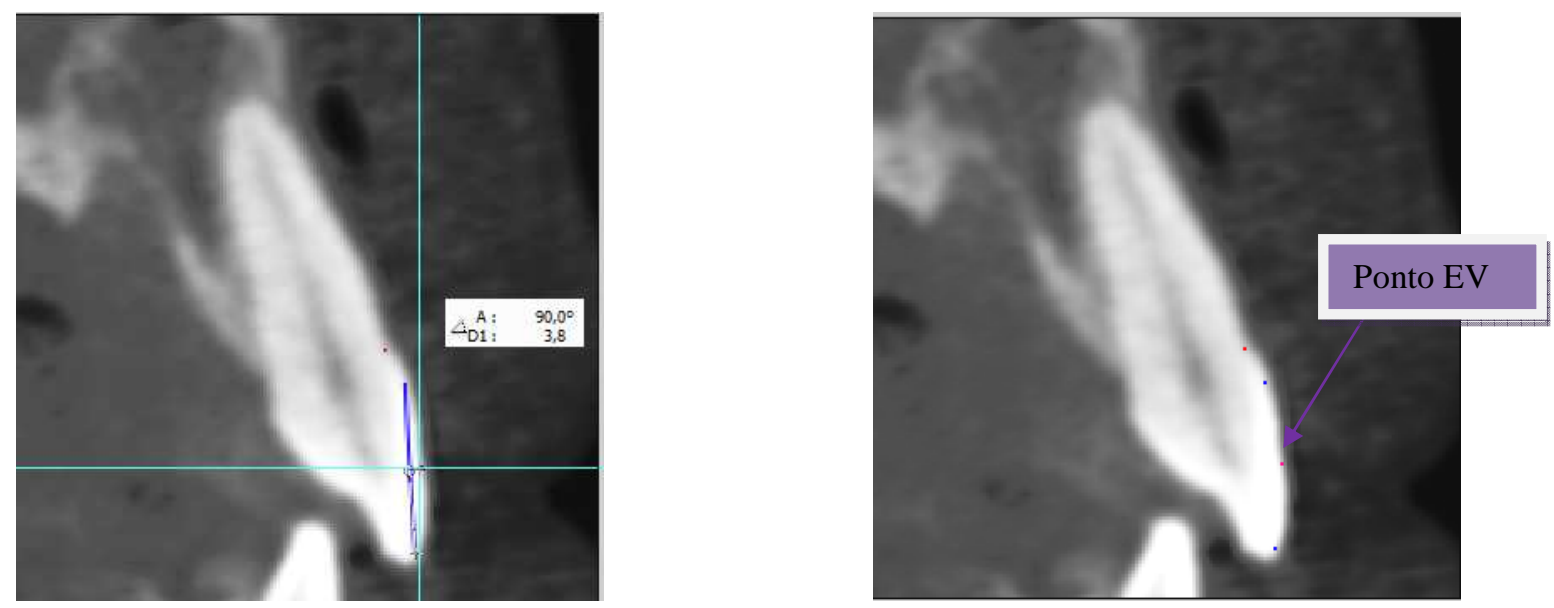

Figura 24 - Ponto EV.

Para determinar a inclinação de cada coroa dentária, utilizou-se a ferramenta de angulação do software ajustando um dos braços do ângulo, de modo a ficar perpendicular ao plano oclusal e o outro a tocar no ponto EV tangenciando igual número de pontos possíveis na face vestibular, abaixo e acima do ponto EV. O vértice do ângulo deveria estar sobre o ponto $\mathrm{EV}$, entretanto, para facilitar sua leitura e o posicionamento correto da reta que passa por EV, padronizou-se posicionar o vértice do ângulo no local onde esta reta corta o plano oclusal, pois neste ponto o valor do ângulo permanece o mesmo daquele medido sobre o ponto EV. O valor da inclinação é dado automaticamente pelo software. Para valores positivos, o braço do ângulo perpendicular ao plano oclusal estava à frente da extremidade (braço) que passava pelo ponto EV, e, para valores negativos, esse braço perpendicular estava atrás da extremidade que passava pelo ponto EV (Fig. 25). No exemplo abaixo, a inclinação obtida foi de $+5,6^{0}$. Como a extremidade perpendicular ao plano oclusal estava à frente daquela que tangenciou a face vestibular, o valor foi considerado positivo. 


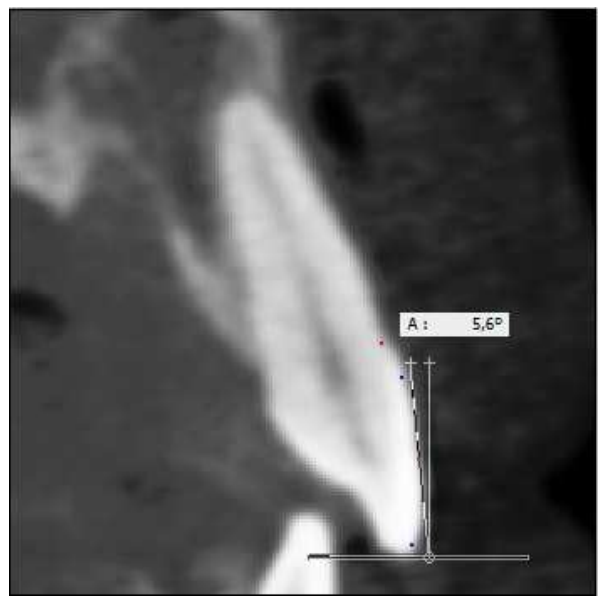

Figura 25 - Inclinação.

\subsection{AFERIÇÃO DA ANGULAÇÃO}

Para cada um dos seis dentes anteriores, superiores e inferiores, foi medida a angulação do longo eixo do dente a partir da imagem panorâmica da arcada dentária (Fig.26). Optou-se por medir a angulação do longo eixo do dente como um todo e não da coroa dentária, uma vez que seria difícil determinar o local exato do ponto EV nessa imagem (panorâmica), ao contrário da inclinação, cujo protocolo padroniza a localização do ponto EV.

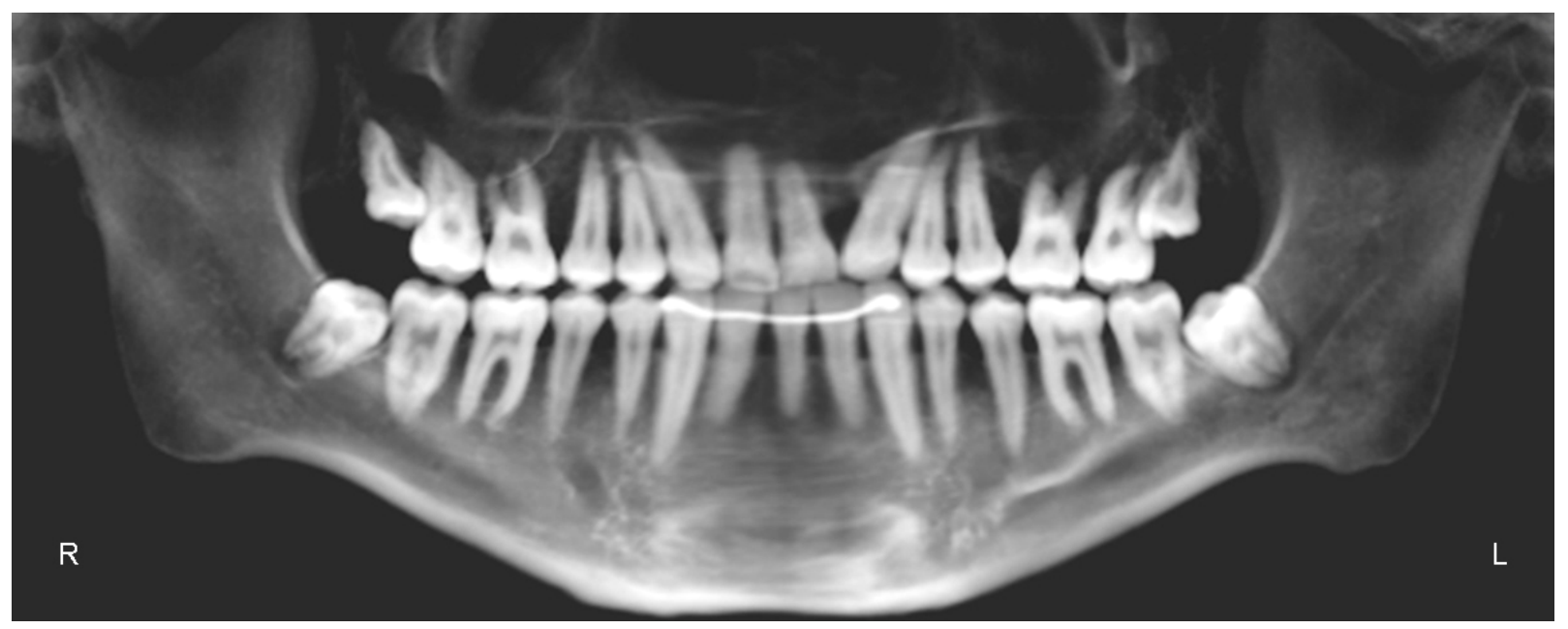

Figura 26 - Panorâmica. 
Primeiramente determinou-se um ponto no centro da borda incisal e um segundo ponto que, idealmente, deveria estar localizado no ápice radicular. Entretanto, nos casos de raízes com dilacerações, esse ponto foi colocado no centro da raiz imediatamente antes do inicio da dilaceração. Com auxilio da ferramenta régua de medida, traçou-se uma reta a partir do ponto no centro da borda incisal (ou face oclusal) até o ponto do ápice radicular que representava o longo eixo do dente (Fig.27).

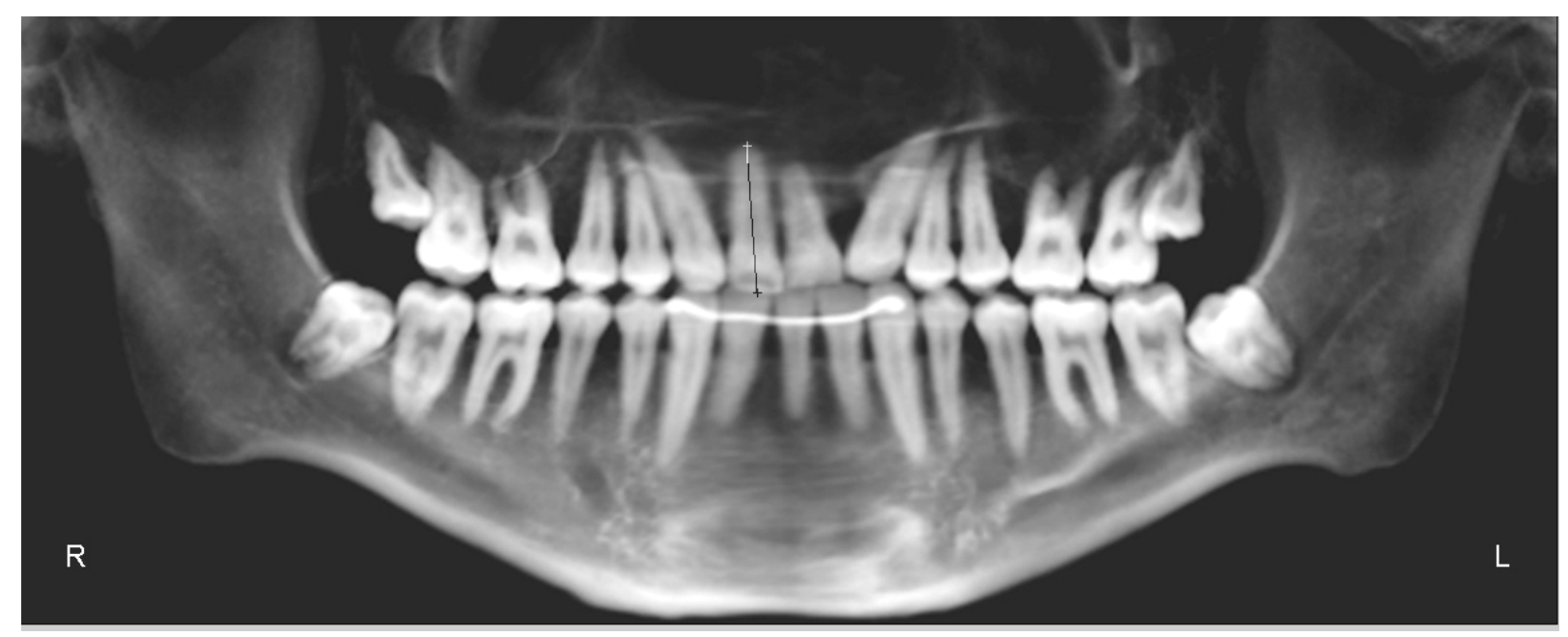

Figura 27 - Reta representando longo eixo do dente.

A seguir, com a ferramenta de ângulo na própria régua, foi traçada uma nova reta perpendicular ao plano oclusal com vértice localizado sobre esse plano. O ângulo formado entre as duas retas (perpendicular ao plano oclusal e paralela ao longo eixo) determinou o valor da angulação para aquele dente. Esse valor foi considerado positivo quando o braço do ângulo que representava o longo eixo dentário estivesse a distal do braço perpendicular ao plano oclusal e negativo quando estivesse a mesial.

A figura 28 representa a obtenção do valor da angulação. Nesse exemplo, a extremidade (braço) do ângulo paralela ao longo eixo dentário está localizada a distal da extremidade perpendicular ao plano oclusal, sendo o valor obtido, de $4,1^{0}$, considerado positivo. 


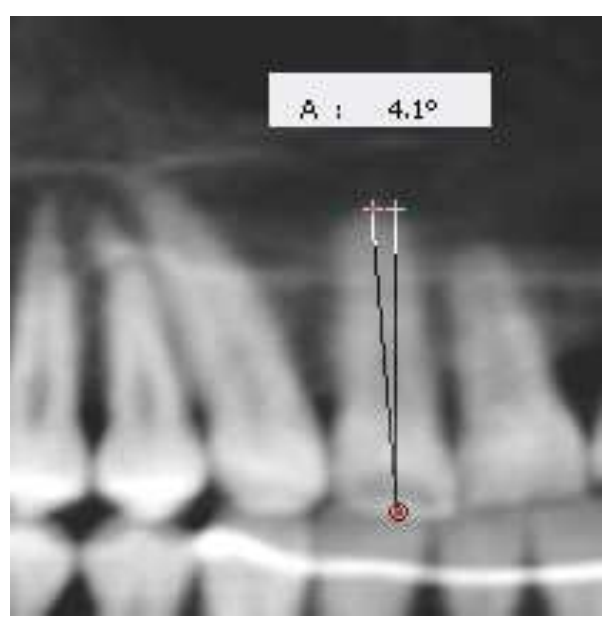

Figura 28 - Angulação.

Para cada dente avaliado foram anotadas cinco variáveis: coroa anatômica, coroa clínica, ponto EV, inclinação e angulação.

Após o período de um mês, todas as medidas foram repetidas para todos os pacientes da amostra e separadas em M1 e M2 (medida 1 e medida 2 respectivamente), seguindo os mesmos passos descritos anteriormente para a obtenção dos valores de inclinação e angulação. 



\section{RESULTADOS}

A fim de se analisar os resultados obtidos para a medição da inclinação e angulação dentária por meio desta metodologia e para a comparação dos resultados obtidos com aqueles publicados na literatura, as medidas foram submetidas aos seguintes testes estatísticos:

- Média de M1 e M2, desvio-padrão e média total (M1+M2/2);

- Distribuição normal (Teste de Shapiro-Wilk);

- Erro Casual (precisão)

- Fórmula de Dahlberg;

- Erro sistemático (exatidão)

- Teste t pareado para variáveis com distribuição simétrica (normal);

- Teste de Wilcoxon para variáveis com distribuição assimétrica (anormal).

Para verificar se as medidas de M1(medida 1) e M2 (medida 2) de cada dente examinado apresentavam um padrão de distribuição normal, aplicou-se o teste de ShapiroWilk a um nível de significância de $0,05(\alpha=5 \%)$. A distribuição normal é um pré-requisito para a utilização de testes paramétricos. Para os valores com distribuição normal $(p \geq 0,05)$, em M1 e M2, foi aplicado o teste $t$ de student de modo a verificar o erro sistemático. Para valores com distribuição anormal ( $<<0,05)$, em M1 e/ou em M2, foi utilizado um teste não paramétrico - teste de Wilcoxon.

Encontrou-se uma distribuição assimétrica $(\mathrm{p}<0,05)$ em M1 para os valores de coroa anatômica, coroa clínica e ponto EV para o dente 21 e inclinação do dente 41 em M2.

Para melhor elucidação do estudo, os dados coletados em M1 e M2 podem ser conferidos nos apêndices de A a Z. 
Os resultados obtidos, no presente estudo, em relação à média de M1, M2, média total, diferença entre as médias e distribuição da amostra estão dispostos nas tabelas comparativas numeradas de 1 a 10, de acordo com dos testes estatísticos realizados. Na figura 29 é possível visualizar os valores de inclinação e angulação para os dentes anteriores superiores e inferiores neste estudo. Os valores positivos significam inclinação vestibular ou angulação mesial das coroas dentárias, enquanto que os valores negativos indicam inclinação lingual ou palatina e angulação distal.

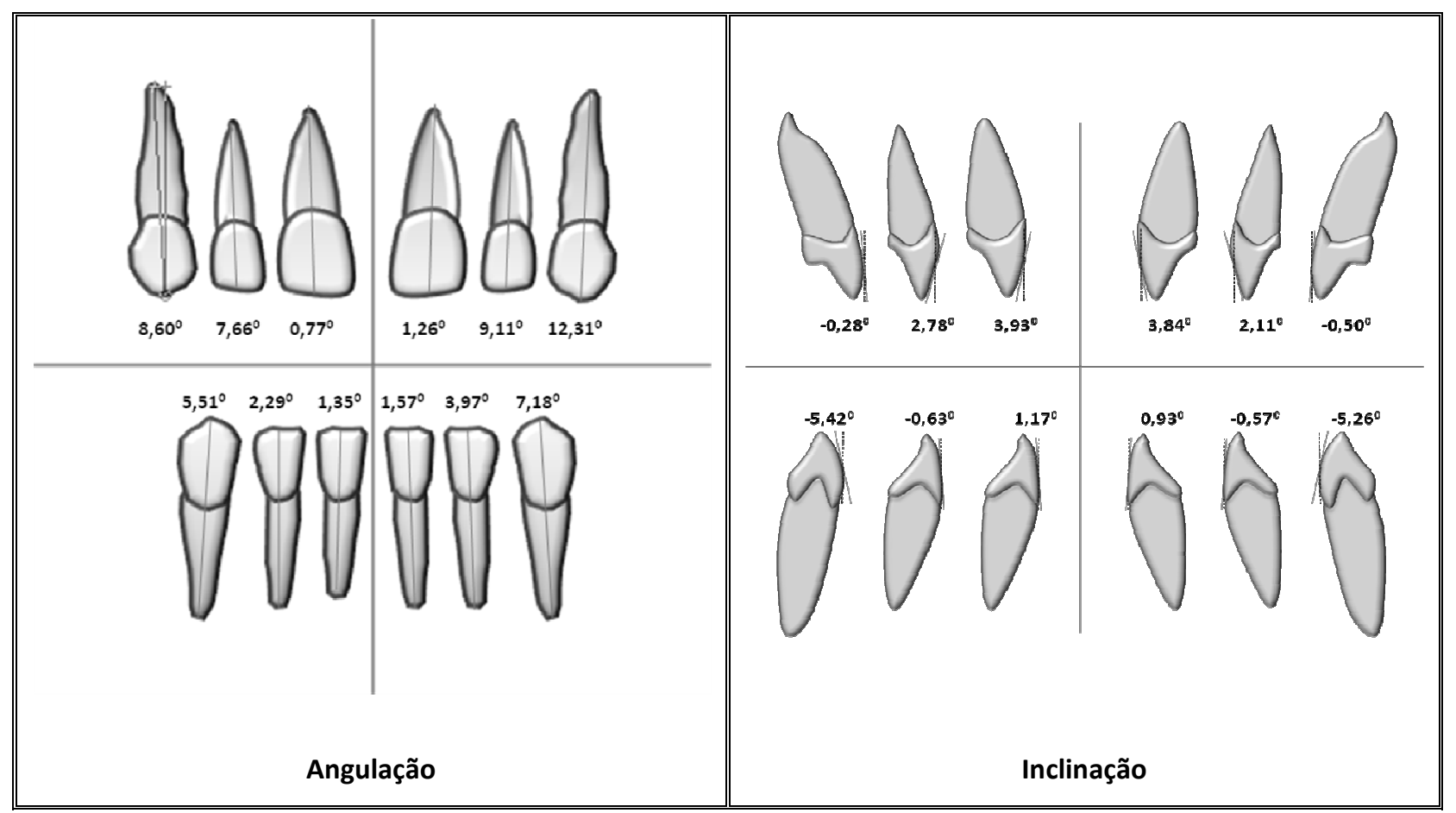

Figura 29 - Valores médios de inclinação e angulação na amostra selecionada. 
Tabela 1 - Testes estatísticos para coroa anatômica no arco superior.

\begin{tabular}{|c|c|c|c|c|c|c|}
\hline \multicolumn{2}{|c|}{ Coroa Anatômica } & \multirow{2}{*}{$\begin{array}{c}\text { Média (mm) } \\
8,69\end{array}$} & \multirow{2}{*}{$\begin{array}{c}\text { Desvio-Padrão } \\
\pm 1,1799\end{array}$} & \multirow{2}{*}{$\begin{array}{c}\text { Teste de Normalidade } \\
\text { Shapiro-Wilk } \\
0,1787^{*}\end{array}$} & \multirow{2}{*}{$\begin{array}{l}\begin{array}{c}\text { Média Total } \\
(\mathrm{mm})\end{array} \\
M 1+M 2 / 2\end{array}$} & \multirow{2}{*}{$\begin{array}{c}\text { Diferença entre as } \\
\text { médias } \\
\text { M1-M2 (mm) }\end{array}$} \\
\hline & M 1 & & & & & \\
\hline Dente 13 & M 2 & 8,80 & $\pm 1,2737$ & $0,8120^{*}$ & 8,75 & 0,11 \\
\hline & M 1 & 9,28 & $\pm 1,0569$ & $0,4118^{*}$ & & \\
\hline Dente 12 & M 2 & 9,22 & $\pm 0,7950$ & $0,6455^{*}$ & 9,25 & 0,06 \\
\hline & M 1 & 9,71 & $\pm 0,9117$ & $0,4739 *$ & & \\
\hline Dente 11 & M 2 & 9,58 & $\pm 1,0674$ & $0,5728 *$ & 9,64 & 0,13 \\
\hline & M 1 & 9,51 & $\pm 1,0115$ & $0,0455^{* *}$ & & \\
\hline Dente 21 & M 2 & 9,72 & $\pm 1,0654$ & $0,0542 *$ & 9,62 & $-0,21$ \\
\hline & M 1 & 9,56 & $\pm 0,9633$ & $0,4387^{*}$ & & \\
\hline Dente 22 & M 2 & 9,66 & $\pm 0,8019$ & $0,4371 *$ & 9,61 & $-0,10$ \\
\hline & M 1 & 8,59 & $\pm 1,2313$ & $0,9190 *$ & & \\
\hline Dente 23 & M 2 & 8,66 & $\pm 1,2817$ & $0,8510 *$ & 8,62 & $-0,07$ \\
\hline
\end{tabular}

*Distribuição normal ou simétrica $(P>0,05) \quad$ ** Distribuição anormal ou assimétrica $(P<0,05)$

Tabela 2 - Testes estatísticos para coroa clínica no arco superior.

\begin{tabular}{|c|c|c|c|c|c|c|}
\hline \multicolumn{2}{|c|}{ Coroa Clínica } & \multirow{2}{*}{$\begin{array}{c}\text { Média (mm) } \\
6,89\end{array}$} & \multirow{2}{*}{$\begin{array}{c}\text { Desvio-Padrão } \\
\pm 1,1799\end{array}$} & \multirow{2}{*}{$\begin{array}{c}\text { Teste de Normalidade } \\
\text { Shapiro-Wilk } \\
0,1787^{*}\end{array}$} & \multirow{2}{*}{$\begin{array}{l}\begin{array}{l}\text { Média Total } \\
(\mathrm{mm})\end{array} \\
M 1+M 2 / 2\end{array}$} & \multirow{2}{*}{$\begin{array}{c}\text { Diferença entre as } \\
\text { médias } \\
\text { M1 - M2 (mm) }\end{array}$} \\
\hline & M 1 & & & & & \\
\hline Dente 13 & M 2 & 7,00 & $\pm 1,2737$ & $0,8120 *$ & 6,95 & 0,11 \\
\hline & M 1 & 7,48 & $\pm 1,0569$ & 0,4118* & & \\
\hline Dente 12 & M 2 & 7,42 & $\pm 0,795$ & $0,6455^{*}$ & 7,45 & 0,06 \\
\hline & M 1 & 7,91 & $\pm 0,9117$ & 0,4739* & & \\
\hline Dente 11 & M 2 & 7,78 & $\pm 1,0674$ & $0,5728^{*}$ & 7,85 & 0,13 \\
\hline & M 1 & 7,71 & $\pm 1,0115$ & $0,0455^{* *}$ & & \\
\hline Dente 21 & M 2 & 7,92 & $\pm 1,0654$ & $0,0542 *$ & 7,87 & $-0,21$ \\
\hline & M 1 & 7,76 & $\pm 0,9633$ & $0,7767 *$ & & \\
\hline Dente 22 & M 2 & 7,86 & $\pm 0,8019$ & $0,4371^{*}$ & 7,81 & $-0,10$ \\
\hline Dente 23 & $\begin{array}{l}\text { M } 1 \\
\text { M } 2\end{array}$ & 6,79 & $\begin{array}{l} \pm 1,2313 \\
\pm 1,2817\end{array}$ & $\begin{array}{l}0,9190^{*} \\
0,8510^{*}\end{array}$ & 6,82 & $-0,07$ \\
\hline
\end{tabular}


Tabela 3 - Testes estatísticos para ponto EV no arco superior.

\begin{tabular}{|c|c|c|c|c|c|c|}
\hline \multicolumn{2}{|c|}{ Ponto EV } & \multirow{2}{*}{$\begin{array}{l}\text { Média } \\
3,47\end{array}$} & \multirow{2}{*}{$\begin{array}{c}\text { Desvio-Padrão } \\
\pm 0,5908\end{array}$} & \multirow{2}{*}{$\begin{array}{c}\text { Teste de Normalidade } \\
\text { Shapiro-Wilk } \\
0,2376^{*}\end{array}$} & \multirow{2}{*}{$\begin{array}{l}\text { Média Total } \\
(\mathrm{mm}) \\
M 1+M 2 / 2\end{array}$} & \multirow{2}{*}{$\begin{array}{c}\text { Diferença entre as } \\
\text { médias } \\
\text { M1-M2 (mm) }\end{array}$} \\
\hline & M 1 & & & & & \\
\hline Dente 13 & M 2 & 3,45 & $\pm 0,6433$ & $0,4767^{*}$ & 3,46 & 0,02 \\
\hline & M 1 & 3,76 & $\pm 0,5225$ & $0,4800^{*}$ & & \\
\hline Dente 12 & M 2 & 3,72 & $\pm 0,4025$ & $0,6890^{*}$ & 3,74 & 0,04 \\
\hline & M 1 & 3,94 & $\pm 0,4773$ & $0,2841^{*}$ & & \\
\hline Dente 11 & M 2 & 3,86 & \pm 0.5918 & $0.4949 *$ & 3,90 & 0,09 \\
\hline & M 1 & 3,88 & $\pm 0,5051$ & $0,0447^{* *}$ & & \\
\hline Dente 21 & M 2 & 3,97 & $\pm 0,5293$ & $0,0833^{*}$ & 3,93 & $-0,09$ \\
\hline & M 1 & 3,92 & $\pm 0,4764$ & $0,5112^{*}$ & & \\
\hline Dente 22 & M 2 & 3,96 & $\pm 0,3782$ & $0,4215^{*}$ & 3,94 & $-0,04$ \\
\hline & M 1 & 3,42 & $\pm 0,6320$ & $0,9040^{*}$ & & \\
\hline Dente 23 & M 2 & 3,51 & $\pm 0,5555$ & $0,3021^{*}$ & 3,47 & $-0,09$ \\
\hline
\end{tabular}

*Distribuição normal ou simétrica $(P>0,05)$ ** Distribuição anormal ou assimétrica $(P<0,05)$

Tabela 4 - Testes estatísticos para inclinação no arco superior.

\begin{tabular}{|c|c|c|c|c|c|c|}
\hline \multicolumn{2}{|c|}{ Inclinação } & \multirow{2}{*}{$\begin{array}{l}\text { Média } \\
-0,45^{0}\end{array}$} & \multirow{2}{*}{$\begin{array}{c}\text { Desvio-Padrão } \\
\pm 4,5921\end{array}$} & \multirow{2}{*}{$\begin{array}{c}\text { Teste de Normalidade } \\
\text { Shapiro-Wilk } \\
0,3956^{*}\end{array}$} & \multirow{2}{*}{$\begin{array}{l}\text { Média Total } \\
M 1+M 2 / 2\end{array}$} & \multirow{2}{*}{$\begin{array}{c}\text { Diferença entre as } \\
\text { médias } \\
\text { M1 - M2 }\end{array}$} \\
\hline & M 1 & & & & & \\
\hline Dente 13 & M 2 & $-0,11^{0}$ & $\pm 4,9045$ & $0,3084^{*}$ & $-0,28^{0}$ & $-0,34^{0}$ \\
\hline & M 1 & $2,54^{\circ}$ & $\pm 2,8254$ & $0,5705^{*}$ & & \\
\hline Dente 12 & M 2 & $3,02^{0}$ & $\pm 2,7779$ & $0,8015^{*}$ & $2,78^{\circ}$ & $-0,48^{0}$ \\
\hline & M 1 & $3,98^{0}$ & $\pm 5,9497$ & $0,9714^{*}$ & & \\
\hline Dente 11 & M 2 & $3,88^{\circ}$ & $\pm 5,7111$ & $0,6269 *$ & $3,93^{0}$ & $0,10^{\circ}$ \\
\hline & M 1 & $3,80^{\circ}$ & $\pm 6,9501$ & $0,7370^{*}$ & & \\
\hline Dente 21 & M 2 & $3,87^{0}$ & $\pm 6,9596$ & $0,9208 *$ & $3,84^{0}$ & $-0,07^{0}$ \\
\hline & M 1 & $1,96^{0}$ & $\pm 3,2254$ & $0,6516^{*}$ & & \\
\hline Dente 22 & M 2 & $2,26^{\circ}$ & $\pm 2,7410$ & $0,2410^{*}$ & $2,11^{0}$ & $-0,30^{\circ}$ \\
\hline & M 1 & $-0,72^{0}$ & $\pm 5,1495$ & $0.6569 *$ & & \\
\hline Dente 23 & M 2 & $-0,27^{0}$ & $\pm 5,3446$ & $0,3505^{*}$ & $.0,50^{\circ}$ & $-0,35^{0}$ \\
\hline
\end{tabular}


Tabela 5 - Testes estatísticos para angulação no arco superior.

\begin{tabular}{|c|c|c|c|c|c|c|}
\hline \multicolumn{2}{|c|}{ Angulação } & \multirow{2}{*}{$\begin{array}{l}\text { Média } \\
8,85^{\circ}\end{array}$} & \multirow{2}{*}{$\begin{array}{c}\text { Desvio-Padrão } \\
\pm 5,3558\end{array}$} & \multirow{2}{*}{$\begin{array}{c}\text { Teste de Normalidade } \\
\text { Shapiro-Wilk } \\
0,4551^{*}\end{array}$} & \multirow{3}{*}{$\begin{array}{c}\text { Média Total } \\
\text { M1 + M2 / } 2 \\
8,60^{\circ}\end{array}$} & \multirow{3}{*}{$\begin{array}{c}\text { Diferença entre as } \\
\text { médias } \\
\text { M1-M2 } \\
0,50^{\circ}\end{array}$} \\
\hline & M 1 & & & & & \\
\hline Dente 13 & M 2 & $8,35^{\circ}$ & $\pm 5,2623$ & $0,4475^{*}$ & & \\
\hline & M 1 & $7,72^{0}$ & $\pm 4,9631$ & $0,9813^{*}$ & & \\
\hline Dente 12 & M 2 & $7,60^{\circ}$ & $\pm 4,9020$ & $0,7517^{*}$ & $7,66^{\circ}$ & $0,12^{0}$ \\
\hline & M 1 & $0,72^{0}$ & $\pm 5,1504$ & $0,0926^{*}$ & & \\
\hline Dente 11 & M 2 & $0,82^{0}$ & $\pm 5,3284$ & $0,2491 *$ & $0,77^{0}$ & $-0,10^{\circ}$ \\
\hline & M 1 & $1,37^{0}$ & $\pm 7,3530$ & $0,3795 *$ & & \\
\hline Dente 21 & M 2 & $1,15^{\circ}$ & $\pm 7,4093$ & $0,2610^{*}$ & $1,26^{\circ}$ & $0,22^{0}$ \\
\hline & M 1 & $9,30^{\circ}$ & $\pm 8,7724$ & $0,2486^{*}$ & & \\
\hline Dente 22 & M 2 & $8,92^{\circ}$ & $\pm 8,7799$ & $0,3237^{*}$ & $9,11^{0}$ & $0,38^{0}$ \\
\hline Dente 23 & $\begin{array}{l}\text { M } 1 \\
\text { M } 2\end{array}$ & $12,49^{0}$ & $\begin{array}{l} \pm 4,2809 \\
\pm 4,5492\end{array}$ & $0,3005^{*}$ & $12,31^{0}$ & $0,36^{0}$ \\
\hline
\end{tabular}

*Distribuição normal ou simétrica $(P>0,05) \quad$ ** Distribuição anormal ou assimétrica $(P<0,05)$

Tabela 6 - Testes estatísticos para coroa anatômica no arco inferior.

\begin{tabular}{|c|c|c|c|c|c|c|}
\hline \multicolumn{2}{|c|}{ Coroa Anatômica } & \multirow{2}{*}{$\begin{array}{c}\text { Média (mm) } \\
10,41\end{array}$} & \multirow{2}{*}{$\begin{array}{c}\text { Desvio-Padrão } \\
\pm 1,2270\end{array}$} & \multirow{2}{*}{$\begin{array}{c}\text { Teste de Normalidade } \\
\text { Shapiro-Wilk } \\
0,9869^{*}\end{array}$} & \multirow{2}{*}{$\begin{array}{c}\text { Média Total (mm) } \\
\qquad M 1+M 2 / 2\end{array}$} & \multirow{2}{*}{$\begin{array}{c}\text { Diferença entre as } \\
\text { médias } \\
\text { M1-M2 (mm) }\end{array}$} \\
\hline & M 1 & & & & & \\
\hline Dente 33 & M 2 & 10,48 & $\pm 1,1736$ & $0,6258 *$ & 10,45 & $-0,07$ \\
\hline & M 1 & 8,96 & $\pm 0,7560$ & $0,4896 *$ & & \\
\hline Dente 32 & M 2 & 9,19 & $\pm 0,9504$ & $0,4635^{*}$ & 9,08 & $-0,23$ \\
\hline & M 1 & 8,58 & $\pm 0,9367$ & $0,87571^{*}$ & & \\
\hline Dente 31 & M 2 & 8,80 & $\pm 0,7958$ & $0,9159 *$ & 8,69 & $-0,22$ \\
\hline & M 1 & 8,78 & $\pm 0,5826$ & $0,3321^{*}$ & & \\
\hline Dente 41 & M 2 & 8,94 & $\pm 0,7468$ & $0,2695^{*}$ & 8,86 & $-0,17$ \\
\hline & M 1 & 8,93 & $\pm 0,6584$ & $0,4090^{*}$ & & \\
\hline Dente 42 & M 2 & 9,02 & $\pm 0,8377$ & $0,5737^{*}$ & 8,98 & $-0,09$ \\
\hline & M 1 & 10,22 & $\pm 0,8121$ & $0,5284^{*}$ & & \\
\hline Dente 43 & M 2 & 10,52 & $\pm 0,9976$ & $0,8357^{*}$ & 10,37 & $-0,30$ \\
\hline
\end{tabular}


Tabela 7 - Testes estatísticos para coroa clínica no arco inferior.

\begin{tabular}{|c|c|c|c|c|c|c|}
\hline \multicolumn{2}{|c|}{ Coroa Clínica } & \multirow{2}{*}{$\begin{array}{c}\text { Média }(\mathrm{mm}) \\
8,61\end{array}$} & \multirow{2}{*}{$\begin{array}{c}\text { Desvio-Padrão } \\
\pm 1,2270\end{array}$} & \multirow{2}{*}{$\begin{array}{c}\text { Teste de Normalidade } \\
\text { Shapiro-Wilk } \\
0,9869^{*}\end{array}$} & \multirow{2}{*}{$\begin{array}{l}\begin{array}{c}\text { Média Total } \\
(\mathrm{mm})\end{array} \\
M 1+M 2 / 2\end{array}$} & \multirow{2}{*}{$\begin{array}{c}\text { Diferença entre as } \\
\text { médias } \\
M 1-M 2(\mathrm{~mm})\end{array}$} \\
\hline & M 1 & & & & & \\
\hline Dente 33 & M 2 & 8,68 & $\pm 1,1736$ & $0,6258^{*}$ & 8,65 & $-0,07$ \\
\hline & M 1 & 7,16 & $\pm 0,7560$ & $0,4896^{*}$ & & \\
\hline Dente 32 & M 2 & 7,39 & $\pm 0,9504$ & $0,4635^{*}$ & 7,28 & $-0,23$ \\
\hline & M 1 & 6,78 & $\pm 0,9367$ & $0,8571^{*}$ & & \\
\hline Dente 31 & M 2 & 7,00 & $\pm 0,7958$ & $0,9159 *$ & 6,89 & $-0,22$ \\
\hline & M 1 & 6,98 & $\pm 0,5826$ & $0,3321^{*}$ & & \\
\hline Dente 41 & M 2 & 7,14 & $\pm 0,7468$ & $0,2695^{*}$ & 7,06 & $-0,17$ \\
\hline & M 1 & 7,13 & $\pm 0,6584$ & $0,4090^{*}$ & & \\
\hline Dente 42 & M 2 & 7,22 & $\pm 0,8377$ & $0,5737^{*}$ & 7,18 & $-0,09$ \\
\hline & M 1 & 8,42 & $\pm 0,8121$ & $0,5284^{*}$ & & \\
\hline Dente 43 & M 2 & 8,72 & $\pm 0,9976$ & $0,8357 *$ & 8,57 & $-0,30$ \\
\hline
\end{tabular}

*Distribuição normal ou simétrica $(P>0,05)$ ** Distribuição anormal ou assimétrica $(P<0,05)$

Tabela 8 - Testes estatísticos para ponto EV no arco inferior.

\begin{tabular}{|c|c|c|c|c|c|c|}
\hline \multicolumn{2}{|c|}{ Ponto EV } & \multirow{2}{*}{$\begin{array}{c}\text { Média }(\mathrm{mm}) \\
4,34\end{array}$} & \multirow{2}{*}{$\begin{array}{c}\text { Desvio-Padrão } \\
\pm 0,6186\end{array}$} & \multirow{2}{*}{$\begin{array}{c}\text { Teste de Normalidade } \\
\text { Shapiro-Wilk } \\
0,9900^{*}\end{array}$} & \multirow{2}{*}{$\begin{array}{c}\text { Média Total } \\
M 1+M 2 / 2(\mathrm{~mm})\end{array}$} & \multirow{2}{*}{$\begin{array}{c}\text { Diferença entre as } \\
\text { médias } \\
\text { M1-M2 (mm) }\end{array}$} \\
\hline & M 1 & & & & & \\
\hline Dente 33 & M 2 & 4,37 & $\pm 0,6019$ & $0,5850^{*}$ & 4,36 & $-0,03$ \\
\hline & M 1 & 3,64 & $\pm 0,4402$ & $0,4552^{*}$ & & \\
\hline Dente 32 & M 2 & 3,72 & $\pm 0,4662$ & $0,4388 *$ & 3,68 & $-0,08$ \\
\hline & M 1 & 3,40 & $\pm 0,4595$ & $0,8403^{*}$ & & \\
\hline Dente 31 & M 2 & 3,53 & $\pm 0,3889$ & $0,7306^{*}$ & 3,47 & $-0,13$ \\
\hline & M 1 & 3,51 & $\pm 0,2977$ & $0,2466^{*}$ & & \\
\hline Dente 41 & M 2 & 3,60 & $\pm 0,3873$ & $0,3048^{*}$ & 3,56 & $-0,09$ \\
\hline & M 1 & 3,58 & $\pm 0,3293$ & $0,5802^{*}$ & & \\
\hline Dente 42 & M 2 & 3,55 & $\pm 0,4577$ & $0,4274^{*}$ & 3,57 & 0,03 \\
\hline & M 1 & 4,24 & $\pm 0,4115$ & $0,4642^{*}$ & & \\
\hline Dente 43 & M 2 & 4,44 & $\pm 0,5103$ & $0,9128 *$ & 4,34 & $-0,20$ \\
\hline
\end{tabular}


Tabela 9 - Testes estatísticos para inclinação no arco inferior.

\begin{tabular}{|c|c|c|c|c|c|c|}
\hline \multicolumn{2}{|c|}{ Inclinação } & \multirow{2}{*}{$\begin{array}{l}\text { Média } \\
-5,35^{0}\end{array}$} & \multirow{2}{*}{$\begin{array}{c}\text { Desvio-Padrão } \\
\pm 4,5224\end{array}$} & \multirow{2}{*}{$\begin{array}{c}\text { Teste de Normalidade } \\
\text { Shapiro-Wilk } \\
0,5525^{*}\end{array}$} & \multirow{2}{*}{$\begin{array}{l}\text { Média Total } \\
M 1+M 2 / 2\end{array}$} & \multirow{2}{*}{$\begin{array}{c}\text { Diferença entre as } \\
\text { médias } \\
M 1-M 2\end{array}$} \\
\hline & M 1 & & & & & \\
\hline Dente 33 & M 2 & $-5,16^{0}$ & $\pm 4,1650$ & $0,4681 *$ & $-5,26^{0}$ & $-0,19^{0}$ \\
\hline & M 1 & $-0,55^{0}$ & $\pm 6,4310$ & $0,6676 *$ & & \\
\hline Dente 32 & M 2 & $-0,59^{\circ}$ & $\pm 6,5842$ & $0,8473^{*}$ & $-0,57^{0}$ & $0,04^{0}$ \\
\hline & M 1 & $0,86^{0}$ & $\pm 5,8969$ & $0,2783^{*}$ & & \\
\hline Dente 31 & M 2 & $1,00^{\circ}$ & $\pm 5,7718$ & $0,3108^{*}$ & $0,93^{0}$ & $-0,14^{0}$ \\
\hline & M 1 & $1,02^{0}$ & $\pm 6,0611$ & $0,0552 *$ & & \\
\hline Dente 41 & M 2 & $1,32^{0}$ & $\pm 6,1088$ & $0,0337 * *$ & $1,17^{0}$ & $-0,30^{\circ}$ \\
\hline & M 1 & $-0,75^{0}$ & $\pm 6,0215$ & $0,2684^{*}$ & & \\
\hline Dente 42 & M 2 & $-0,50^{\circ}$ & $\pm 5,7291$ & $0,2366^{*}$ & $-0,63^{0}$ & $-0,25^{0}$ \\
\hline Dente 43 & $\begin{array}{l}\text { M } 1 \\
\text { M } 2\end{array}$ & $\begin{array}{l}-5,36^{0} \\
-5,47^{0}\end{array}$ & $\begin{array}{l} \pm 4,5683 \\
\pm 4,1907\end{array}$ & $0,7608^{*}$ & $-5,42^{0}$ & $0,11^{0}$ \\
\hline
\end{tabular}

*Distribuição normal ou simétrica $(\mathrm{P}>0,05) \quad$ ** Distribuição anormal ou assimétrica $(\mathrm{P}<0,05)$

Tabela 10 - Testes estatísticos para angulação no arco inferior.

\begin{tabular}{|c|c|c|c|c|c|c|}
\hline \multicolumn{2}{|c|}{ Angulação } & \multirow{2}{*}{$\begin{array}{l}\text { Média } \\
7,17^{0}\end{array}$} & Desvio-Padrão & $\begin{array}{c}\text { Teste de Normalidade } \\
\text { Shapiro-Wilk }\end{array}$ & \multirow{2}{*}{$\begin{array}{l}\text { Média Total } \\
M 1+M 2 \text { / } 2\end{array}$} & \multirow{2}{*}{$\begin{array}{c}\text { Diferença entre } \\
\text { as médias } \\
\text { M1 - M2 }\end{array}$} \\
\hline & M 1 & & $\pm 2,5465$ & $0,9900^{*}$ & & \\
\hline Dente 33 & M 2 & $7,19^{\circ}$ & $\pm 2,3183$ & $0,7858^{*}$ & $7,18^{0}$ & $-0,02^{0}$ \\
\hline & M 1 & $4,00^{\circ}$ & $\pm 3,9511$ & $0,4084^{*}$ & & \\
\hline Dente 32 & M 2 & $3,93^{0}$ & $\pm 3,9234$ & $0,2359 *$ & $3,97^{0}$ & $0,07^{0}$ \\
\hline & M 1 & $1,48^{\circ}$ & $\pm 3,3535$ & $0,1544^{*}$ & & \\
\hline Dente 31 & M 2 & $1,65^{\circ}$ & $\pm 3,2783$ & $0,3118^{*}$ & $1,57^{0}$ & $-0,17^{0}$ \\
\hline & M 1 & $1,28^{0}$ & $\pm 3,7134$ & $0,6978^{*}$ & & \\
\hline Dente 41 & M 2 & $1,41^{0}$ & $\pm 3,7153$ & $0,7935^{*}$ & $1,35^{\circ}$ & $-0,13^{0}$ \\
\hline & M 1 & $2,34^{0}$ & $\pm 3,2695$ & $0,6116^{*}$ & & \\
\hline Dente 42 & M 2 & $2,23^{\circ}$ & $\pm 3,1756$ & $0,5314^{*}$ & $2,29^{\circ}$ & $0,11^{0}$ \\
\hline & M 1 & $5,54^{0}$ & $\pm 3,0130$ & $0,6045^{*}$ & & \\
\hline Dente 43 & M 2 & $5,48^{\circ}$ & $\pm 3,0243$ & $0,6478^{*}$ & $5,51^{0}$ & $0,06^{0}$ \\
\hline
\end{tabular}


Para testar a precisão do método aplicado, utilizou-se a fórmula de Dahlberg de modo a verificar o erro casual - componente do erro de medição que varia de uma forma imprevisível quando se efetuam várias medições da mesma grandeza (INMETRO 2007). A fórmula proposta para o erro casual é a que segue (Houston 1983):

$$
\mathrm{Se}^{2}=\sum \mathbf{d}^{2} / 2 \mathrm{n}
$$

No qual Se representa o erro de Dahlberg; $\sum \mathbf{d}^{2}$ corresponde ao somatório dos quadrados das diferenças entre as primeiras e segundas medições e $\mathbf{2 n}$ representa o dobro do número dos casos em que as medidas foram repetidas.

Os valores obtidos para erro casual variaram de $0,12^{0}$ a $0,71^{0}$ sendo considerada uma variação muito baixa, com resultados bastante precisos entre M1 e M2 para todas as variáveis estudadas.

Os erros sistemáticos são aqueles que afetam o valor da medida e podem ser definidos como o componente do erro da medição que se mantém constante ou varia de forma previsível quando se efetuam várias medições de uma mesma grandeza (Barthem 2000). Os testes para erro sistemático permitiram avaliar se as medidas obtidas foram exatas ou se houve viés do operado, do participante ou do instrumento utilizado, definindo assim o grau de concordância entre o resultado da medição e o valor verdadeiro convencional da grandeza medida. Nos resultados obtidos, não houve diferença estatisticamente significante $(p>0,05)$ entre a primeira e a segunda medição. Esses valores sugerem que o método empregado tem uma boa exatidão, com medidas bastante semelhantes entre M1 e M2 para todas as variáveis estudadas. Seguem as tabelas de 11 a 14 com os testes estatísticos para erro do método. 
Tabela 11 - Testes estatísticos para erro do método em coroa anatômica e coroa clínica.

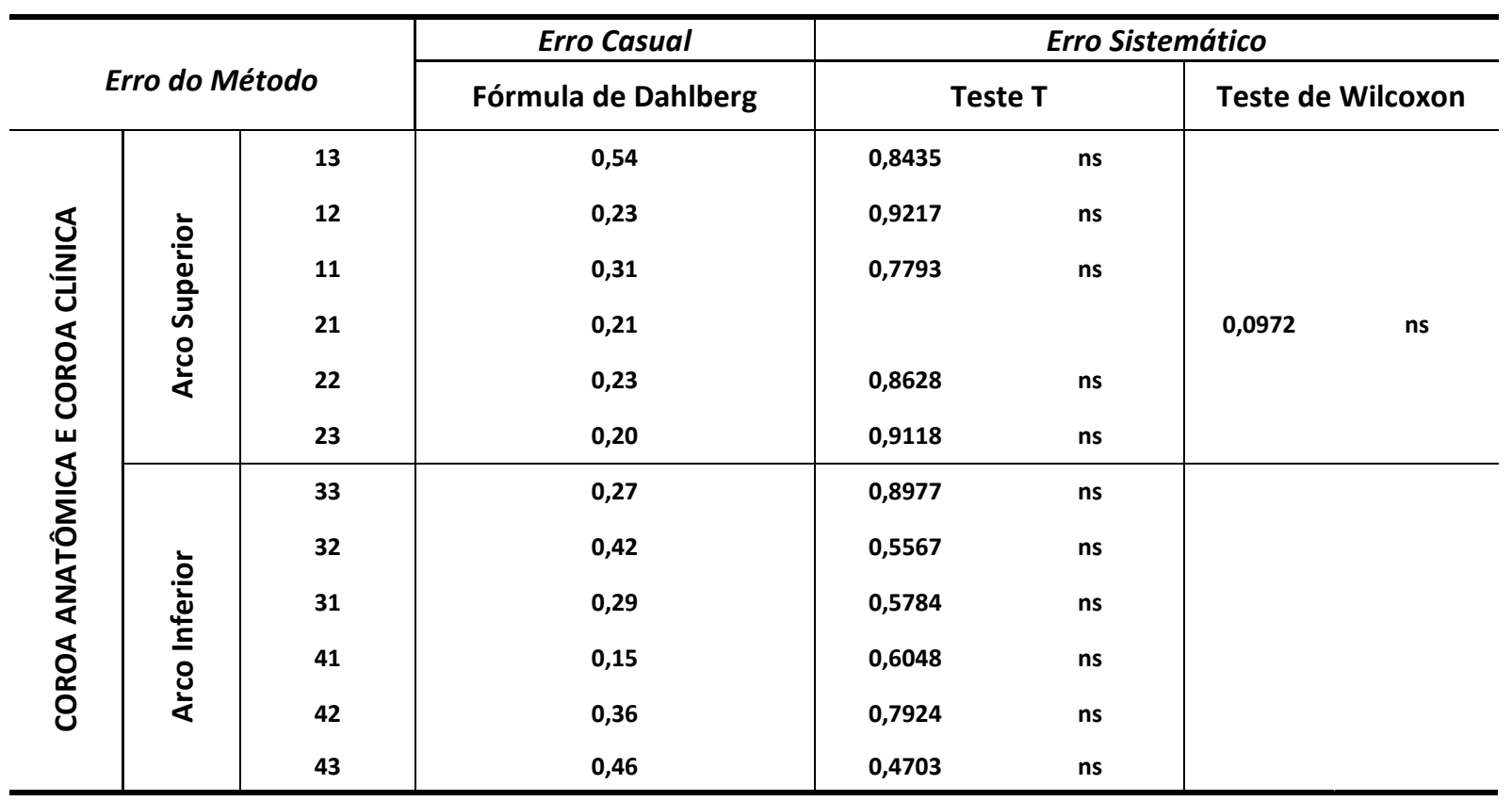

ns - não significante $(P>0,05)$

Tabela 12 - Testes estatísticos para erro do método em ponto EV.

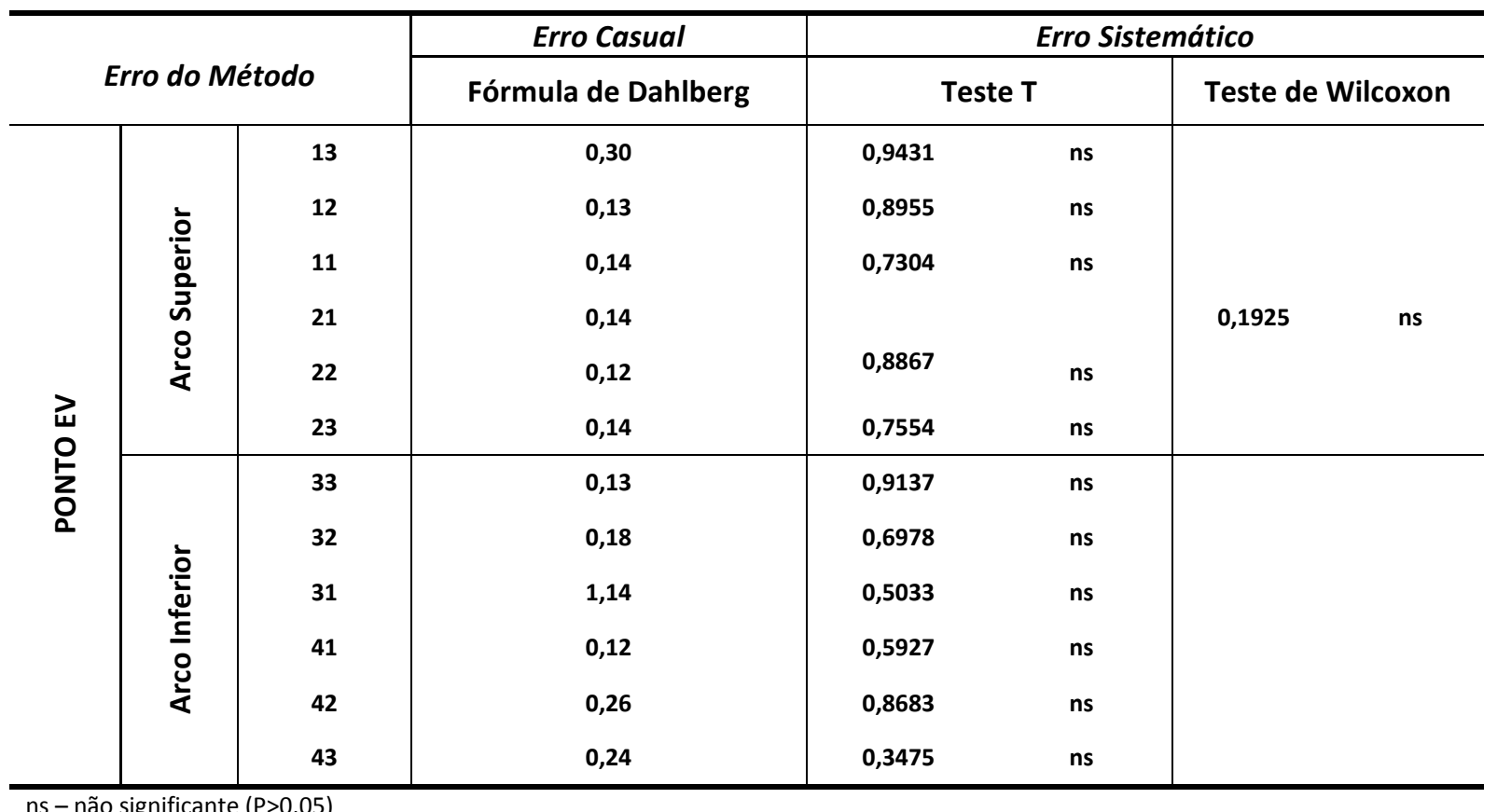


Tabela 13 - Testes estatísticos para erro do método em inclinação.

\begin{tabular}{|c|c|c|c|c|c|c|c|}
\hline \multirow{2}{*}{\multicolumn{3}{|c|}{ Erro do Método }} & \multirow{2}{*}{$\begin{array}{c}\text { Erro Casual } \\
\text { Fórmula de Dahlberg } \\
0,42\end{array}$} & \multicolumn{4}{|c|}{ Erro Sistemático } \\
\hline & & & & \multicolumn{2}{|c|}{ Teste T } & \multicolumn{2}{|c|}{ Teste de Wilcoxon } \\
\hline \multirow{2}{*}{ 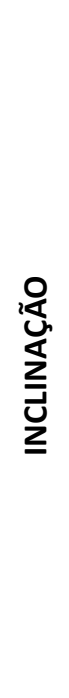 } & 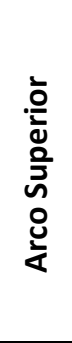 & $\begin{array}{l}13 \\
12 \\
11 \\
21 \\
22 \\
23\end{array}$ & $\begin{array}{l}0,42 \\
0,41 \\
0,46 \\
0,48 \\
0,62 \\
0,69\end{array}$ & $\begin{array}{l}0,8746 \\
0,7933 \\
0,9714 \\
0,9823 \\
0,8780 \\
0,8562\end{array}$ & $\begin{array}{l}\text { ns } \\
\text { ns } \\
\text { ns } \\
\text { ns } \\
\text { ns } \\
\text { ns }\end{array}$ & & \\
\hline & 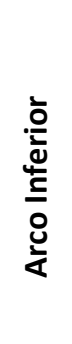 & $\begin{array}{l}33 \\
32 \\
31 \\
41 \\
42 \\
43\end{array}$ & $\begin{array}{l}0,60 \\
0,47 \\
0,44 \\
0,43 \\
0,50 \\
0,44\end{array}$ & $\begin{array}{l}0,9232 \\
0,9892 \\
0,9578\end{array}$ & $\begin{array}{l}\text { ns } \\
\text { ns } \\
\text { ns }\end{array}$ & 0,1614 & ns \\
\hline
\end{tabular}

ns - não significante $(P>0,05)$

Tabela 14 - Testes estatísticos para erro do método em angulação.

\begin{tabular}{|c|c|c|c|c|c|c|}
\hline \multirow{2}{*}{\multicolumn{3}{|c|}{ Erro do Método }} & \multirow{2}{*}{$\begin{array}{c}\text { Erro Casual } \\
\text { Fórmula de Dahlberg } \\
0,43\end{array}$} & \multicolumn{3}{|c|}{ Erro Sistemático } \\
\hline & & & & \multicolumn{2}{|c|}{ Teste T } & \multirow[t]{2}{*}{ Teste de Wilcoxon } \\
\hline \multirow{2}{*}{ 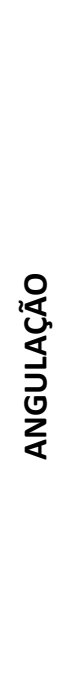 } & 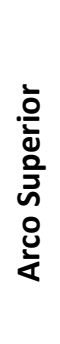 & $\begin{array}{l}13 \\
12 \\
11 \\
21 \\
22 \\
23\end{array}$ & $\begin{array}{l}0,43 \\
0,47 \\
0,41 \\
0,52 \\
0,71 \\
0,65\end{array}$ & $\begin{array}{l}0,8356 \\
0,9703 \\
0,9682 \\
0,9476 \\
0,9471 \\
0,8666\end{array}$ & $\begin{array}{l}\text { ns } \\
\text { ns } \\
\text { ns } \\
\text { ns } \\
\text { ns } \\
\text { ns }\end{array}$ & \\
\hline & 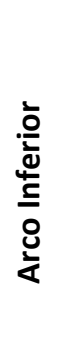 & $\begin{array}{l}33 \\
32 \\
31 \\
41 \\
42 \\
43\end{array}$ & $\begin{array}{l}0,52 \\
0,28 \\
0,25 \\
0,34 \\
0,33 \\
0,36\end{array}$ & $\begin{array}{l}0,9855 \\
0,9687 \\
0,9100 \\
0,9402 \\
0,9400 \\
0,9650\end{array}$ & $\begin{array}{l}\text { ns } \\
\text { ns } \\
\text { ns } \\
\text { ns } \\
\text { ns }\end{array}$ & \\
\hline
\end{tabular}


De forma a elucidar melhor os resultados obtidos, seguem as tabelas de 15 a 22 com os valores de M1, M2 e a média para cada grupo de dente avaliado em cada paciente.

Tabela 15 - Valores de M1, M2 e média de inclinação para os dentes 13 e 23.

\begin{tabular}{|c|c|c|c|c|c|c|}
\hline \multirow{2}{*}{ Inclinação } & \multicolumn{3}{|c|}{ Dente 13} & \multicolumn{3}{|c|}{ Dente 23} \\
\hline & M1 & M2 & Média & M1 & M2 & Média \\
\hline Paciente 1 & $-0,7$ & $-0,1$ & $-0,40$ & 1,8 & 2,9 & 2,35 \\
\hline Paciente 2 & 1,0 & 1,3 & 1,15 & 1,0 & 1,9 & 1,45 \\
\hline Paciente 3 & $-5,7$ & $-5,4$ & $-5,55$ & $-6,2$ & $-5,0$ & 5,60 \\
\hline Paciente 4 & $-7,6$ & $-7,6$ & $-7,60$ & $-4,6$ & $-4,3$ & $-4,45$ \\
\hline Paciente 5 & 6,6 & 7,3 & 6,95 & 7,0 & 6,8 & 6,90 \\
\hline Paciente 6 & 3,3 & 3,9 & 3,60 & 5,1 & 5,8 & 5,45 \\
\hline Paciente 7 & 1,1 & 2,1 & 1,16 & 0,9 & 2,4 & 1,65 \\
\hline Paciente 8 & $-6,1$ & $-6,8$ & $-6,45$ & $-8,1$ & $-8,0$ & $-8,05$ \\
\hline Paciente 9 & 2,4 & 2,2 & 2,30 & ------ & ------- & ------- \\
\hline Paciente 10 & 1,2 & 2,0 & 1,60 & $-3,4$ & $-4,9$ & $-4,15$ \\
\hline
\end{tabular}

Tabela 16 - Valores de M1, M2 e média de inclinação para os dentes 12,11, 21 e 22.

\begin{tabular}{|c|c|c|c|c|c|c|c|c|c|c|c|c|}
\hline \multirow{2}{*}{ Inclinação } & \multicolumn{3}{|c|}{ Dente 12} & \multicolumn{3}{|c|}{ Dente 11} & \multicolumn{3}{|c|}{ Dente 21} & \multicolumn{3}{|c|}{ Dente 22} \\
\hline & M1 & M2 & Média & M1 & M2 & Média & M1 & M2 & Média & M1 & M2 & Média \\
\hline Paciente 1 & 2,20 & 2,20 & 2,20 & $-7,20$ & $-7,80$ & $-7,50$ & $-6,30$ & $-7,00$ & $-6,65$ & 4,00 & 4,20 & 4,10 \\
\hline Paciente 2 & ------ & ------ & ------ & 3,10 & 3,60 & 3,35 & 14,30 & 14,30 & 14,30 & ------ & ------ & ------ \\
\hline Paciente 3 & $-1,70$ & $-1,10$ & $-1,40$ & $-0,70$ & 0,00 & $-0,35$ & 1,60 & 1,40 & 1,50 & 3,00 & $-2,30$ & $-2,65$ \\
\hline Paciente 4 & ------ & ------ & ------ & 0,70 & 0,90 & 0,80 & $-4,90$ & $-4,20$ & $-4,55$ & ------ & ------ & ------ \\
\hline Paciente 5 & 3,10 & 3,60 & 3,35 & 5,40 & 5,80 & 5,60 & 4,10 & 5,30 & 4,70 & 1,90 & 2,00 & 1,95 \\
\hline Paciente 6 & 6,20 & 6,50 & 6,35 & ------ & ------ & ------ & 7,20 & 6,20 & 6,70 & 5,50 & 4,50 & 5,00 \\
\hline Paciente 7 & ------ & ------ & ------ & 13,20 & 12,10 & 12,65 & 10,70 & 10,10 & 10,40 & ------ & ------ & ------ \\
\hline Paciente 8 & ------ & ------ & ------ & 6,80 & 6,30 & 6,55 & 1,60 & 1,90 & 1,75 & ------ & ------ & ------ \\
\hline Paciente 9 & ------ & ------ & ------ & 9,30 & 8,40 & 8,85 & 11,00 & 11,80 & 11,40 & ------ & ------ & ------ \\
\hline Paciente 10 & 2,90 & 3,90 & 3,40 & 5,20 & 5,60 & 5,40 & $-1,30$ & $-1,10$ & $-1,20$ & 1,40 & 2,90 & 2,15 \\
\hline
\end{tabular}


Tabela 17 - Valores de M1, M2 e média de inclinação para os dentes 33 e 43.

\begin{tabular}{|c|c|c|c|c|c|c|}
\hline \multirow{2}{*}{ Inclinação } & \multicolumn{3}{|c|}{ Dente 33} & \multicolumn{3}{|c|}{ Dente 43} \\
\hline & M1 & M2 & Média & M1 & M2 & Média \\
\hline Paciente 1 & $-9,80$ & $-10,90$ & $-10,35$ & $-8,00$ & $-8,50$ & $-8,25$ \\
\hline Paciente 2 & $-3,80$ & $-3,50$ & $-3,65$ & $-2,30$ & $-2,10$ & $-2,20$ \\
\hline Paciente 3 & 2,70 & 1,70 & 2,20 & 3,20 & 2,50 & 2,85 \\
\hline Paciente 4 & $-3,90$ & $-3,20$ & $-3,55$ & $-4,80$ & $-5,90$ & $-5,35$ \\
\hline Paciente 5 & $-3,10$ & $-3,80$ & $-3,45$ & $-4,10$ & $-3,90$ & $-4,00$ \\
\hline Paciente 6 & $-8,80$ & $-7,50$ & $-8,15$ & $-8,70$ & $-8,20$ & $-8,45$ \\
\hline Paciente 7 & $-7,40$ & $-7,20$ & $-7,30$ & $-8,00$ & $-8,00$ & $-8,00$ \\
\hline Paciente 8 & $-13,30$ & $-11,90$ & $--12,60$ & $-13,80$ & $-12,70$ & $-13,25$ \\
\hline Paciente 9 & $-3,00$ & $-2,60$ & $-2,80$ & $-4,00$ & $-4,50$ & $-4,25$ \\
\hline Paciente 10 & $-3,10$ & $-2,70$ & $-2,90$ & $-3,10$ & $-3,40$ & $-3,25$ \\
\hline
\end{tabular}

Tabela 18 - Valores de M1, M2 e média de inclinação para os dentes 32, 31, 41 e 42.

\begin{tabular}{|c|c|c|c|c|c|c|c|c|c|c|c|c|}
\hline \multirow{2}{*}{ Inclinação } & \multicolumn{3}{|c|}{ Dente 32} & \multicolumn{3}{|c|}{ Dente 31} & \multicolumn{3}{|c|}{ Dente 41} & \multicolumn{3}{|c|}{ Dente 42} \\
\hline & M1 & M2 & Média & M1 & M2 & Média & M1 & M2 & Média & M1 & M2 & Média \\
\hline Paciente 1 & $\begin{array}{c}- \\
11,90\end{array}$ & $\begin{array}{c}- \\
12,90\end{array}$ & $-12,45$ & $-6,70$ & $-7,10$ & $-6,90$ & $-5,30$ & $-4,00$ & $-4,65$ & $-5,20$ & $-4,40$ & $-4,80$ \\
\hline Paciente 2 & $-2,20$ & $-2,60$ & $-2,40$ & $-3,60$ & $-2,50$ & $-3,05$ & $-3,10$ & $-3,70$ & $-3,40$ & $-2,90$ & $-2,70$ & $-2,80$ \\
\hline Paciente 3 & 12,00 & 11,90 & 11,95 & 12,30 & 11,60 & 11,95 & 12,50 & 13,00 & 12,75 & 12,80 & 12,60 & 12,70 \\
\hline Paciente 4 & 2,50 & 1,60 & 2,05 & 2,00 & 2,30 & 2,15 & $-1,50$ & $-1,50$ & $-1,50$ & 0,80 & 0,50 & 0,65 \\
\hline Paciente 5 & 4,60 & 4,50 & 4,55 & 9,00 & 9,10 & 9,05 & 9,30 & 9,50 & 9,40 & 4,40 & 4,30 & 4,35 \\
\hline Paciente 6 & $-4,60$ & $-5,00$ & $-4,80$ & $-2,40$ & $-1,70$ & $-2,05$ & $-1,70$ & $-1,10$ & $-1,40$ & $-7,40$ & $-6,70$ & $-7,05$ \\
\hline Paciente 7 & $-2,70$ & $-2,10$ & $-2,40$ & $-1,40$ & $-1,70$ & $-1,55$ & $-1,40$ & $-1,70$ & $-1,55$ & $-1,90$ & $-3,10$ & $-2,50$ \\
\hline Paciente 8 & $-3,70$ & $-3,60$ & $-3,65$ & $-1,90$ & $-2,60$ & $-2,25$ & $-2,60$ & $-2,30$ & $-2,45$ & $-7,10$ & $-6,00$ & $-6,55$ \\
\hline Paciente 9 & 3,00 & 3,50 & $-3,25$ & 3,30 & 4,00 & 3,65 & 3,00 & 3,70 & 3,35 & 0,80 & 1,50 & 1,15 \\
\hline Paciente 10 & $-2,50$ & $-1,20$ & $-1,85$ & $-2,00$ & $-1,40$ & $-1,70$ & ------ & ------ & ------ & $-1,80$ & $-1,00$ & $-1,40$ \\
\hline
\end{tabular}


Tabela 19 - Valores de M1, M2 e média de angulação para os dentes 13 e 23.

\begin{tabular}{|c|c|c|c|c|c|c|}
\hline $\begin{array}{l}\text { Tabela } 19 \\
\text { Valores de M1, } \\
\text { M2 e média de } \\
\text { angulação para } \\
\text { os dentes } 13 \text { e } \\
23 . \\
\text { Angulação }\end{array}$ & M1 & Dente & Média & M1 & Dente 2 & Média \\
\hline Paciente 1 & 2,80 & 2,80 & 2,80 & 8,80 & 7,00 & 7,90 \\
\hline Paciente 2 & 13,00 & 12,60 & 12,80 & 13,70 & 12,10 & 12,90 \\
\hline Paciente 3 & 8,30 & 7,10 & 7,70 & 11,50 & 10,50 & 11,00 \\
\hline Paciente 4 & 15,50 & 14,70 & 15,10 & 16,00 & 16,00 & 16,00 \\
\hline Paciente 5 & 12,70 & 12,20 & 12,45 & 15,50 & 16,40 & 15,95 \\
\hline Paciente 6 & 15,60 & 15,30 & 15,45 & 16,90 & 17,00 & 16,95 \\
\hline Paciente 7 & 9,90 & 9,30 & 9,60 & 8,40 & 8,40 & 8,40 \\
\hline Paciente 8 & 0,90 & 0,80 & 0,85 & 16,60 & 16,50 & 16,55 \\
\hline Paciente 9 & 6,30 & 6,00 & 6,15 & ----- & ----- & ---- \\
\hline Paciente 10 & 3,50 & 2,70 & 3,10 & 5,00 & 5,30 & 5,15 \\
\hline
\end{tabular}

Tabela 20 - Valores de M1, M2 e média de angulação para os dentes 12,11, 21 e 22.

\begin{tabular}{|c|c|c|c|c|c|c|c|c|c|c|c|c|}
\hline \multirow{2}{*}{ Angulação } & \multicolumn{3}{|c|}{ Dente 12} & \multicolumn{3}{|c|}{ Dente 11} & \multicolumn{3}{|c|}{ Dente 21} & \multicolumn{3}{|c|}{ Dente 22} \\
\hline & M1 & M2 & Média & M1 & M2 & Média & M1 & M2 & Média & M1 & M2 & Média \\
\hline Paciente 1 & 8,40 & 8,10 & 8,30 & $-0,20$ & $-0,90$ & $-0,55$ & 0,50 & 0,50 & 0,50 & 8,40 & 9,60 & 9,00 \\
\hline Paciente 2 & ----- & ----- & ----- & $-5,80$ & $-5,00$ & $-5,40$ & 8,60 & 9,40 & 9,00 & ----- & ----- & ----- \\
\hline Paciente 3 & 5,00 & 4,00 & 4,50 & 2,60 & 2,60 & 2,60 & 2,90 & 1,70 & 2,30 & 4,50 & 3,00 & 3,75 \\
\hline Paciente 4 & ----- & ----- & ---- & 3,60 & 3,40 & 3,50 & $-3,50$ & $-3,10$ & $-3,30$ & ----- & ----- & ---- \\
\hline Paciente 5 & 1,20 & 2,10 & 1,65 & 2,30 & 2,40 & 2,35 & 0,20 & 0,50 & 0,35 & 1,10 & 1,10 & 1,10 \\
\hline Paciente 6 & 14,40 & 14,70 & 14,55 & ----- & ----- & ----- & 7,40 & 6,10 & 6,75 & 24,00 & 23,40 & 23,70 \\
\hline Paciente 7 & ----- & ----- & ----- & 4,00 & 5,20 & 4,60 & $-3,20$ & $-3,40$ & $-3,30$ & ----- & ----- & ----- \\
\hline Paciente 8 & ----- & ----- & ---- & $-9,50$ & $\begin{array}{c}- \\
10,00\end{array}$ & $-9,75$ & 9,90 & 9,10 & 9,50 & ----- & ----- & ----- \\
\hline Paciente 9 & ----- & ----- & ----- & 2,90 & 2,70 & 2,80 & 5,60 & 6,10 & 5,85 & ----- & ----- & ----- \\
\hline Paciente 10 & 9,60 & 9,10 & 9,35 & 6,60 & 7,00 & 6,80 & $\begin{array}{c}- \\
14,70\end{array}$ & $-15,40$ & $-15,05$ & 8,50 & 7,50 & 8,00 \\
\hline
\end{tabular}


Tabela 21 - Valores de M1, M2 e média de angulação para os dentes 32, 31, 41 e 42.

\begin{tabular}{|c|c|c|c|c|c|c|c|c|c|c|c|c|}
\hline \multirow{2}{*}{ Angulação } & \multicolumn{3}{|c|}{ Dente 32} & \multicolumn{3}{|c|}{ Dente 31} & \multicolumn{3}{|c|}{ Dente 41} & \multicolumn{3}{|c|}{ Dente 42} \\
\hline & M1 & M2 & Média & M1 & M2 & Média & M1 & M2 & Média & M1 & M2 & Média \\
\hline Paciente 1 & 3,70 & 3,90 & 3,80 & 3,20 & 3,20 & 3,20 & $-4,20$ & $-4,00$ & $-4,10$ & $-2,00$ & $-2,00$ & $-2,00$ \\
\hline Paciente 2 & 3,30 & 3,90 & 3,60 & 3,30 & 3,20 & 3,25 & $-1,40$ & $-0,50$ & $-0,95$ & 2,00 & 2,80 & 2,40 \\
\hline Paciente 3 & 4,50 & 3,50 & 4,00 & $-4,80$ & $-4,50$ & $-4,65$ & 4,10 & 4,00 & 4,05 & 3,70 & 3,10 & 3,40 \\
\hline Paciente 4 & 0,50 & 0,50 & 0,50 & 4,40 & 4,60 & 4,50 & $-1,20$ & $-1,90$ & $-1,55$ & 0,70 & 0,70 & 0,70 \\
\hline Paciente 5 & 12,40 & 12,40 & 12,40 & 5,10 & 5,50 & 5,30 & 7,90 & 8,40 & 8,15 & 7,70 & 7,70 & 7,70 \\
\hline Paciente 6 & $-2,60$ & $-2,60$ & $-2,60$ & $-3,50$ & $-2,80$ & $-3,15$ & 3,30 & 3,20 & 3,25 & $-1,50$ & $-1,30$ & $-1,40$ \\
\hline Paciente 7 & 2,70 & 2,70 & 2,70 & 0,80 & 0,30 & 0,55 & 0,30 & 0,30 & 0,30 & 3,70 & 2,80 & 3,25 \\
\hline Paciente 8 & 3,90 & 3,90 & 3,90 & 0,00 & 0,20 & 0,10 & $-0,90$ & $-0,20$ & $-0,55$ & $-1,10$ & $-1,30$ & $-1,20$ \\
\hline Paciente 9 & 4,20 & 3,90 & 4,05 & 3,80 & 4,00 & 3,90 & 3,60 & 3,40 & 3,50 & 5,50 & 5,00 & 5,25 \\
\hline Paciente 10 & 7,40 & 7,20 & 7,30 & 2,50 & 2,80 & 2,65 & ----- & ----- & ----- & 4,70 & 4,80 & 4,75 \\
\hline
\end{tabular}

Tabela 22 - Valores de M1, M2 e média de inclinação para os dentes 33 e 43.

\begin{tabular}{c|ccc|ccc}
\hline Angulação & M1 & $\begin{array}{c}\text { Dente 33 } \\
\text { M2 }\end{array}$ & Média & M1 & $\begin{array}{c}\text { Dente 43 } \\
\text { M2 }\end{array}$ & Média \\
\hline Paciente 1 & 5,40 & 6,30 & $\mathbf{5 , 8 5}$ & 0,20 & 0,80 & $\mathbf{0 , 5 0}$ \\
Paciente 2 & 9,30 & 8,30 & $\mathbf{8 , 8 0}$ & 8,20 & 8,70 & $\mathbf{8 , 4 5}$ \\
Paciente 3 & 8,90 & 8,40 & $\mathbf{8 , 6 5}$ & 8,10 & 7,40 & $\mathbf{7 , 7 5}$ \\
Paciente 4 & 2,60 & 2,90 & $\mathbf{2 , 7 5}$ & 1,30 & 1,10 & $\mathbf{1 , 2 0}$ \\
Paciente 5 & 11,50 & 10,60 & $\mathbf{1 1 , 0 5}$ & 9,90 & 10,10 & $\mathbf{1 0 , 0 0}$ \\
Paciente 6 & 6,80 & 6,40 & $\mathbf{6 , 6 0}$ & 5,30 & 5,60 & $\mathbf{5 , 4 5}$ \\
Paciente 7 & 6,30 & 6,20 & $\mathbf{6 , 2 5}$ & 6,70 & 6,70 & $\mathbf{6 , 7 0}$ \\
Paciente 8 & 8,00 & 9,30 & $\mathbf{8 , 6 5}$ & 4,50 & 3,40 & $\mathbf{3 , 9 5}$ \\
Paciente 9 & 4,80 & 4,70 & $\mathbf{4 , 7 5}$ & 5,40 & 5,50 & $\mathbf{5 , 4 5}$ \\
Paciente 10 & 8,10 & 8,80 & $\mathbf{8 , 4 5}$ & 5,80 & 5,50 & $\mathbf{5 , 6 5}$ \\
\hline
\end{tabular}





\section{DISCUSSÃO}

O paciente com fissura transpalatina bilateral apresenta uma maxila dividida em três segmentos, sendo dois palatinos posteriores e a pré-maxila projetada anteriormente junto ao prolábio. Os segmentos palatinos posteriores tendem a girar em direção medial na região dos caninos e a cruzar a mordida, enquanto que os molares superiores geralmente encontram-se numa relação de classe II em pacientes adultos não operados (Trindade e Silva Filho 2007, p.173-98). As cirurgias primárias para reconstrução do defeito no lábio superior (queiloplastia) têm um efeito sabidamente restritivo no desenvolvimento da face média durante o crescimento do paciente. Embora realizadas muito precocemente - aos três meses de idade - são de extrema importância não somente pelo fator estético, mas pela reabilitação funcional que proporciona aos recém-nascidos. No caso das fissuras bilaterais, entretanto, o fator restritivo imposto pela cinta cicatricial das cirurgias primárias é, num primeiro momento, positivo no sentido de reposicionar em direção posterior a pré-maxila, ânterosuperiormente projetada, aproximando-a dos segmentos palatinos posteriores direito e esquerdo. Como consequiência, observa-se também uma inclinação palatina dos incisivos centrais superiores e, frequentemente, ausência dos incisivos laterais ou a presença de dentes conoides ou mal-formados. Nos pacientes não tratados, os incisivos e caninos inferiores tendem a apresentar uma inclinação lingual muito possivelmente para compensar a atresia do arco superior ou pela pressão labial, ou mesmo pela presença de um plano mandibular obtuso (Reis et al 2008).

Neste trabalho, os pacientes selecionados já haviam sido ortodonticamente reabilitados e os valores de inclinação e angulação dentária variaram quando comparados aos pacientes não tratados avaliados por Reis et al (2008), ou quando comparados com valores médios encontrados por Andrews (1972) para pacientes não-fissurados com oclusão normal devido a 
algumas particularidades do paciente com fissura e, consequentemente, do tratamento ortodôntico instituído. Essas particularidades serão discutidas neste capítulo. Os valores de coroa clínica, coroa anatômica e ponto EV serviram apenas como variáveis a serem medidas, de modo a testar a efetividade do método, não havendo a intenção de compará-las com valores da literatura.

Uma grande característica da amostra, como já descrito no capítulo de materiais e métodos, foi a sua heterogeneidade. Esse achado poderá ser observado nos subtópicos descritos neste capítulo de discussão, quando cada paciente foi avaliado de forma individual.

\subsection{AVALIAÇÃO QUALITATIVA DO MÉTODO}

Todas as variáveis avaliadas - coroa anatômica, coroa clínica, ponto EV, inclinação e angulação - mostraram resultados bastante semelhantes em T1 e T2 para todos os testes aplicados na avaliação da precisão, da exatidão e da replicabilidade e comprovam a eficiência do método. Assim pode-se, por exemplo, utilizar esse modelo de avaliação no momento em que se faz o planejamento inicial do tratamento ortodôntico e se definem as metas a serem atingidas ao final. Se um dente se apresenta mal posicionado devido a uma inclinação acentuada para lingual, e deseja-se que ao final do tratamento este dente apresente uma inclinação vestibular para a correção da relação intra e interarcos, então pode-se utilizar este método para saber qual a inclinação inicial e escolher, dentre os bráquetes disponíveis, aquele que contém a inclinação que mais se aproxime da meta a ser atingida. A grande vantagem deste método é que pode ser aplicado individualmente para cada dente o que, em tese, melhoraria muito a qualidade do tratamento e diminuiria o tempo de uso do aparelho. Isso já vem sendo aplicado em modelos de gesso, telerradiografias em norma lateral e radiografias panorâmicas, mas com limitações de técnica uma vez que, ao início do tratamento, dentes muito apinhados e/ou girovertidos são extremamente difíceis de serem medidos em modelos 
de gesso e a panorâmica é, por sua vez, uma imagem bidimensional de uma estrutura tridimensional como a face. Isso implica em distorções, ampliações e sobreposição de estruturas anatômicas, o que prejudica o valor real das medidas (Houston 1983) e a avaliação das relações dente/osso.

A telerradiografia em norma lateral, até então utilizada como instrumento auxiliar de diagnóstico para a realização de traçados cefalométricos e mensuração da inclinação dos incisivos, em relação a suas bases ósseas, teve o seu valor na Ortodontia, mas hoje é inconcebível que seja utilizada com essa finalidade. Esse tipo de imagem radiográfica apresenta sobreposição de todas as estruturas anatômicas de um lado do crânio sobre o outro, além de muito susceptível a alterações de movimentação da cabeça do paciente. Segundo Houston (1983), em uma telerradiografia as medidas cujos pontos estão num plano paralelo ao filme não sofrem distorções, mas, quando isso não acontece, tanto as medidas lineares como angulares terão seus valores alterados e deverão ser utilizadas com cautela. Para medir a inclinação do incisivo superior na telerradiografia, por exemplo, utilizava-se como referência o que se imaginava ser o ápice radicular e a coroa deste dente, mas quão real seria a medida de inclinação obtida uma vez que há sobreposição das coroas dos incisivos centrais e laterais e dos ápices radiculares de todos os dentes anteriores na imagem?

A grande contribuição desse exame, entretanto, não está somente em gerar imagens reais para que se possam medir inclinação e angulação dentária, mas sim naquilo que ele permite visualizar e que até então era algo inimaginável para todas as áreas da saúde. Agora, o ortodontista tem a real dimensão da relação que as raízes dentárias mantêm com o osso alveolar de suporte, tanto no plano vestibular como no plano palatino ou lingual, conseguindo, também, visualizar a relação que as raízes mantêm entre si e o efeito do tratamento ortodôntico no periodonto de suporte para cada dente individualmente. Tem também um imenso valor no planejamento ortodôntico, especialmente de dentes impactados, no 
acompanhamento de reabsorções radiculares por permitir a geração de múltiplos cortes de espessura extremamente finos de qualquer plano do dente e nas pesquisas em que, por exemplo, se deseja saber o efeito de um determinado aparelho ortopédico nos dentes e no osso alveolar de suporte. Enfim, a aplicabilidade desse tipo de exame é infinita e a sua contribuição revolucionou a odontologia como um todo. A tomografia computadorizada permite que se avalie cada dente individualmente, sem sobreposições, e com uma imagem em tamanho real. Mesmo a panorâmica e a telerradiografia geradas a partir dos exames tomográficos apresentam bem menos distorção e, consequentemente, uma imagem mais próxima da realidade. Segundo Peck et al (2007), a reconstrução da panorâmica gerada pela tomografia computadorizada proporcionou a obtenção de medidas bastante precisas no que tange à angulação das raízes dentárias, diferente da panorâmica cujos dados não foram precisos e não representou corretamente as angulações dentárias. A desvantagem da panorâmica, em relação às imagens tomográficas, é a distorção dos planos horizontais , inclusive o plano de Andrews, pela própria característica bidimensional.

\subsection{AVALIAÇÃO QUANTITATIVA DO MÉTODO}

Para melhor compreensão dos resultados e favorecer uma discussão mais ampla, as variáveis inclinação e angulação serão comparadas com os trabalhos de Andrews (1972) e Zanelato (2006). Ambos os autores avaliaram pacientes com oclusão normal não tratados ortodonticamente; Andrews avaliou pacientes norte-americanos e Zanelato, brasileiros. Um terceiro artigo publicado por Reis et al (2008), cuja amostra foi composta por pacientes com fissura transforame bilateral para avaliação de tais variáveis, também auxiliará na discussão. Embora tenham avaliado pacientes antes do tratamento ortodôntico ser realizado, os resultados servirão como parâmetro para avaliar a compensação dentária apresentada, ao término do tratamento, na amostra selecionada para este trabalho. Um quarto artigo, publicado 
por Normando et. al (2008), avaliando a angulação dos caninos nas classes I e III, auxiliará na discussão dessa variável para esse grupo de dentes. Somando-se a isso, em cada subtópico, estarão disponíveis tabelas e quadros com os valores comparativos respectivos de modo a facilitar o entendimento da discussão. Os valores dispostos nas tabelas encontram-se também no tópico de resultados de modo mais completo.

\subsubsection{Inclinação}

\subsubsection{Caninos Superiores}

Os valores médios de inclinação encontrados, nos artigos mencionados anteriormente, seguem nos quadros 7 a 12 deste capítulo de discussão.

Quadro 7 - Valores médios de inclinação dos dentes 13 e 23 nos artigos de Andrews (1972), Zanelato (2006), Reis et al (2008) e na pesquisa atual.

\begin{tabular}{|c|c|c|c|c|}
\hline Inclinação & PESQUISA & REIS et al & ANDREWS & ZANELATO \\
\hline canino superior direito & $-0,28^{\circ}$ & $-4,87^{\circ}$ & & \\
\hline canino superior esquerdo & $-0,44^{0}$ & $-4,47^{0}$ & $-7,25^{\circ}$ & $-6,70^{\circ}$ \\
\hline
\end{tabular}

Observou-se que o valor médio da inclinação dos caninos superiores direito e esquerdo foi de e $-0,28^{0}$ e $-0,44^{0}$,respectivamente, sugerindo haver simetria para a posição desses dentes ao final do tratamento ortodôntico. Entretanto, o que se observa ao analisar caso a caso é uma variação nos valores de inclinação do canino direito em relação ao esquerdo em quatro dos dez pacientes avaliados. Reis et al (2008) encontraram valores médios de $-4,87^{0}$ e $-4,47^{0}$ para os mesmos dentes em pacientes fissurados não tratados; Andrews (1972) 
encontrou um valor médio de $-7,25^{0}$ e Zanelato (2006) um valor médio de $-6,70^{0}$ para ambos os lados em oclusões normais de pacientes não-fissurados.

Apesar de negativos, os valores médios de inclinação atribuídos aos caninos superiores, após o tratamento ortodôntico, divergiram daqueles encontrados na literatura sugerindo menor inclinação palatina destes dentes em relação aos estudos comparativos. Esse achado pode ser devido, primeiramente, à expansão rápida da maxila necessária para alinhamento dos segmentos maxilares posteriores com a pré-maxila e para a correção da mordida cruzada posterior, oferecendo condições para a realização da cirurgia de enxerto ósseo alveolar secundário. A quantidade de expansão é necessariamente grande e proporcional à severidade da má-oclusão. Além disso, a ausência de tecido ósseo no palato duro faz com que a expansão seja altamente recidivante. Quanto maior a expansão, maior também o efeito de inclinação vestibular das coroas dentárias.

$\mathrm{Na}$ tentativa de manter as relações oclusais transversais adequadas e minimizar a recidiva da expansão, possivelmente o ortodontista acaba por compensar a perda da dimensão transversal do arco diminuindo a inclinação palatina dos dentes posteriores superiores especialmente na região dos caninos vulnerável pela atuação da fissura, fazendo com que apresentem valores de inclinação muito próximos de zero ao término do tratamento.

Neste estudo, encontraram-se valores máximo e mínimo de $+7,3^{0}$ e $-7,6^{0}$ de inclinação para o dente 13 e de $+7,0^{0}$ e $-8,1^{0}$ para o dente 23 . Observou-se que os valores de inclinação máximo e mínimo dos dentes 13 e 23 variaram bastante entre os pacientes da amostra, bem como variaram os valores de inclinação do lado direito em relação ao esquerdo em um mesmo paciente. Essa variação encontrada entre os pacientes e entre os lados opostos do arco dentário em um mesmo paciente, para os valores de inclinação, possivelmente possa ser devido ao pequeno tamanho da amostra e à heterogeneidade observada neste estudo em todos os aspectos. Por exemplo, o critério de inclusão dos pacientes na pesquisa foi apenas finalização 
adequada e oportunidade do exame tomográfico e não se levou em consideração outras variáveis como padrão facial, etnia, tratamento compensatório ou ortodôntico-cirúrgico e características oclusais como primeiros pré-molares fazendo função de caninos e caninos substituindo incisivos laterais ausentes. Obviamente estas características alteram os valores de inclinação observados.

Reis et al (2008) observaram a mesma discrepância de valores máximos e mínimos em sua amostra, confirmando a grande variação existente entre os casos desse mesmo tipo de fissura. Para esses pacientes “variação é a regra, não a exceção” (Subtelny 1996).

A heterogeneidade da amostra pode ser constatada analisando-se os casos individualmente, o que permite identificar os fatores que contribuíram para os resultados.

Uma grande característica notada nessa amostra foi a presença dos primeiros prémolares substituindo os caninos adjacentes, e estes substituindo os incisivos laterais frequentemente ausentes. Apesar de se buscar em todo tratamento ortodôntico que esses dentes substitutos, após a finalização do tratamento, apresentem características de inclinação e angulação dos dentes aos quais substituíram, há forte indícios, nesta pesquisa, de que isso não ocorre. Muito provavelmente esses dentes perderam as características de inclinação e angulação presentes anteriormente, mas não adquiriram totalmente as novas características que lhes embutiram pelo tratamento em sua nova posição na arcada dentária. Na amostra selecionada, os pacientes \#1, 3, 6 e 10 possuíam os primeiros pré-molares realizando função de caninos, o que representa $40 \%$ da amostra. Esse fato, isoladamente, possivelmente explicaria as grandes diferenças notadas entre os casos tratados. Somando-se a isso, os pacientes \#1, 3 e 7 foram reabilitados com cirurgia ortognática, sendo que o paciente \#1 teve a maxila e mandíbula operadas e os demais, apenas a maxila; os pacientes \#2, 8 e 9 apresentaram espaços protéticos com agenesia dos incisivos laterais, sendo que o paciente \#8 não fez enxerto ósseo alveolar, e o paciente \#9 apresentou também agenesia do canino 
superior esquerdo. Cada achado mencionado acima interfere nos valores de inclinação dos caninos superiores. Na tabela 23, os valores médios de inclinação de todos os pacientes da amostra podem ser conferidos. Comparando os valores de angulação entre os sujeitos da pesquisa, a variação encontrada não foi estatisticamente significante ( $p>0,05)$.

Tabela 23 - Valores médios de inclinação dos dentes 13 e 23 para cada paciente.

\begin{tabular}{|c|c|c|c|c|c|c|c|c|c|c|}
\hline Paciente & $\# 1$ & \#2 & \#3 & $\# 4$ & $\# 5$ & $\# 6$ & $\# 7$ & \#8 & $\# 9$ & $\# 10$ \\
\hline dente 13 & $-0,40^{\circ}$ & $+1,15^{\circ}$ & $-5,55^{0}$ & $-7,60^{\circ}$ & $+6,95^{\circ}$ & $+3,60^{\circ}$ & $+1,16^{0}$ & $-6,45^{0}$ & $+2,30^{\circ}$ & $+1,60^{\circ}$ \\
\hline dente 23 & $+2,35^{\circ}$ & $+1,45^{0}$ & $+5,60^{\circ}$ & $-4,45^{0}$ & $+6,90^{\circ}$ & $+5,45^{0}$ & $+1,65^{\circ}$ & $-8,05^{0}$ & ---- & $-4,15^{0}$ \\
\hline
\end{tabular}

Os tópicos analisados no parágrafo anterior proporcionaram grande contribuição para esses resultados. Além disso, como já descrito anteriormente, os casos selecionados apresentaram apenas finalização adequada e não "ideal" e, por estarem em fase de contenção, é de se esperar alguma forma de recidiva, especialmente na relação interarcos pela ausência de osso na região palatina, inicialmente rompida pela fissura. Entre os pacientes \# 1, 4, 6 e 10 pôde-se notar ausência de simetria para os caninos superiores de um lado do arco dentário em relação ao outro no que concerne à inclinação, embora clinicamente esse fator não tenha causado prejuízo estético. O ponto mais interessante, entretanto, é que, dos quatro pacientes com pré-molares substituindo caninos, três estão incluídos neste grupo com assimetria no posicionamento dentário, sugerindo que o ortodontista deve, em seu planejamento inicial, considerar essa variável e acompanhar atentamente os casos conduzidos dessa maneira, de modo a obter o melhor resultado estético possível. A movimentação dos pré-molares para o espaço dos caninos ocorre nas situações onde se planeja o fechamento do espaço deixado pela ausência dos incisivos laterais mesializando os dentes posteriores. 


\section{Prescrição de Bráquetes}

Capelozza Filho et al (1999) sugerem a utilização de bráquetes com inclinação de $-5^{0}$ para os caninos superiores, nos padrões I e II e de $-2^{0}$ para o padrão III. Andrews (1989) sugere a prescrição de bráquetes com $-7^{0}$ para as classes I, II e III.

Neste estudo, caninos superiores tiveram uma média de inclinação de $-0,36^{0}$, valor esse negativo e muito próximo de zero, aproximando-se mais da prescrição padrão III de Capelozza cujo valor é de $-2^{0}$.

\section{Incisivos Centrais e Laterais Superiores}

Os incisivos centrais e laterais superiores merecem um destaque à parte por estarem adjacentes à fissura e sofrerem grande influência na presença dela. A agenesia dos incisivos laterais é um achado extremamente frequente nestes pacientes, uma vez que a fissura rompe o rebordo na altura dos germes dentários dos dentes 12 e 22. Quando presentes, estes dentes apresentam as mais variadas formas, tamanhos e posições, tanto de coroa como de raiz. É comum, por exemplo, irromperem na região palatina, atrás dos incisivos centrais.

Outro achado comum nas fissuras bilaterais é o pré-canino, um microdente com formato conoide, presente nos segmentos palatinos posteriores, à frente dos caninos, portanto chamados assim de pré-caninos. Quando possuem estrutura radicular e osso alveolar de suporte adequados e um posicionamento no arco que permita incluí-los no tratamento, eles podem ser movimentados para a posição dos incisivos laterais ausentes.

Os incisivos centrais, por sua vez, apresentam suas raízes contra-anguladas (em direção à linha média) devido à falta de osso alveolar em suas faces adjacentes à fissura num momento prévio à cirurgia de enxerto ósseo alveolar e, mesmo após a cirurgia, poderão ocorrer perdas em altura deste osso na região enxertada. 


\subsubsection{Incisivos Laterais Superiores}

$\mathrm{Na}$ ausência dos incisivos laterais, duas condutas divergentes podem ser definidas no planejamento: fechamento do espaço com mesialização dos dentes posteriores ou manutenção do espaço para posterior reabilitação protética. O que se observou nos pacientes desta amostra, e também na rotina clínica, é que nos pacientes onde foi deixado espaço protético para a reabilitação com implantes ou próteses, após o tratamento ortodôntico, houve maior perda em altura e também em espessura do osso alveolar na região do enxerto. Isso é esperado pois, em áreas onde o osso alveolar perde sua função de suporte radicular, ele é reabsorvido com o passar do tempo. Já nos pacientes em que houve estímulo desse osso, com a movimentação de dentes para ocupar o espaço deixado pela ausência dos incisivos laterais, a perda óssea foi menor, principalmente naqueles onde havia pré-caninos ou incisivos laterais conoides ou mal-formados. Com isso pôde-se esperar encontrar, neste trabalho, valores bastante divergentes daqueles publicados na literatura, em especial para os incisivos laterais, por suas particularidades descritas acima. No quadro 8 é possível visualizar a média dos valores de inclinação encontrados nesta pesquisa e nos artigos da literatura mencionados no início da discussão.

Quadro 8 - Valores médios de inclinação dos dentes 12 e 22 nos artigos de Andrews (1972), Zanelato (2006), Reis et al (2008) e na pesquisa atual.

\begin{tabular}{|c|c|c|c|c||}
\hline Inclinação & PESQUISA & REIS et al & ANDREWS & ZANELATO \\
\hline Incisivo lateral superior direito & $+2,72^{\circ}$ & & & \\
\hline Incisivo lateral superior esquerdo & $+2,11^{\circ}$ & - & $+4,42^{0}$ & $\mathbf{+ 6 , 1 9}^{0}$ \\
\hline
\end{tabular}

----dentes não medidos (ausentes)

Para os incisivos laterais encontraram-se os seguintes valores de inclinação: $+2,72^{0}$ para o dente $12 \mathrm{e}+2,11^{0}$ para o dente 22 , mostrando haver simetria ente os lados direito e 
esquerdo na amostra como um todo. Os valores de inclinação máximo e mínimo foram respectivamente: $+6,50^{\circ}$ e $-1,70^{\circ}$ para o incisivo lateral direito e $5,50^{\circ}$ e $-3,00^{\circ}$ para o incisivo lateral esquerdo e podem ser conferidos na tabela 16 do tópico Resultados. Andrews (1972) encontrou valores médios de inclinação, para esses dentes, de $+4,42^{0}$ e Zanelato (2006) de $+6,19^{0}$. Apesar de esses dentes estarem presentes em sete dos dez pacientes avaliados, quatro eram caninos que substituíram os incisivos laterais ausentes e dois eram conoides ou précaninos com coroas reconstruídas com próteses, e apenas um apresentava incisivo lateral com coroa dentária hígida. Os dois incisivos conóides foram excluídos da amostra por apresentarem coroas protéticas, o que poderia interferir no resultado uma fez que a anatomia inicial da coroa foi modificada pela prótese podendo alterar o local exato do ponto EV. Assim, apenas cinco pacientes tiveram incisivos laterais incluídos na pesquisa e os valores médios encontrados para cada paciente podem ser conferidos na tabela 24 .

Tabela 24 - Valores médios de inclinação dos dentes 12 e 22 para cada paciente.

\begin{tabular}{|c|c|c|c|c|c|c|c|c|c|c|}
\hline Paciente & $\# 1$ & $\# 2$ & $\# 3$ & $\# 4$ & $\# 5$ & \#6 & $\# 7$ & \#8 & $\# 9$ & $\# 10$ \\
\hline dente 12 & $+2,20^{\circ}$ & - & $-1,40^{\circ}$ & ---- & $+3,35^{\circ}$ & $+6,35^{0}$ & ---- & ---- & ---- & $+3,40^{\circ}$ \\
\hline dente 22 & $4+, 10^{0}$ & ---- & $-2,65^{\circ}$ & ---- & $+1,95^{\circ}$ & $+5,00^{\circ}$ & ---- & ---- & ---- & $+2,15^{\circ}$ \\
\hline
\end{tabular}

Os resultados acima mostram que, apesar de não ter havido grandes discrepâncias entre os lados direito e esquerdo do arco dentário, para um mesmo paciente, todos apresentaram valores divergentes entre os dois lados. Essa assimetria observada foi clinicamente e considerada estatisticamente insignificantes $(p>0,05)$, pois todos apresentavam finalização adequada. Quando se analisam os resultados obtidos para os dentes 12 e 22 entre os pacientes, novamente observa-se uma grande variação (estatisticamente não significante), comprovada anteriormente pelos valores máximo e mínimo descritos, reafirmando a frase citada anteriormente de que "variação é regra e não exceção" (Subtelny 1966). 


\section{Prescrição de Bráquetes}

Segundo Capelozza Filho et al (1999), quando o tratamento ortodôntico é voltado para o fechamento de espaço, nos casos em que há agenesia dos incisivos laterais, os caninos serão movimentados para a mesial de modo a ocupar o espaço deixado pela ausência dos incisivos laterais. Quando isso acontece, os caninos finalizam em classe II e, obrigatoriamente, apresentarão torque vestibular de suas coroas dentárias. O planejamento do tratamento deve prever essa posição final dos caninos e individualizar a finalização do tratamento escolhendo o bráquete que mais se aproxime dessa meta. Os autores sugerem utilizar o bráquete padrão dos caninos superiores colados de forma invertida para que a inclinação contida de $-5^{\circ}$ fique positiva e a angulação de $+8^{\circ}$ permaneça a mesma, favorecendo a finalização ideal do tratamento ortodôntico nessas circunstâncias.

Capelozza Filho et al (1999) sugerem a utilização de bráquetes com inclinação de $+3^{0}$ para os incisivos laterais, nos padrões I e II e de $+10^{0}$ para o padrão III. Andrews (1989) sugere $+3^{0}$ para classe I, $-2^{0}$ para classe II e $+8^{0}$ para classe III.

Os incisivos laterais apresentaram valores médios de inclinação de $+2,41^{0}$ aproximando-se mais das prescrições padrão I e II de Capelozza e da prescrição classe I de Andrews cujo valor é de $+3^{0}$.

\subsubsection{Incisivos Centrais Superiores}

Quadro 9 - Valores médios de inclinação dos dentes 11 e 21 nos artigos de Andrews (1972), Zanelato (2006), Reis et al (2008) e na pesquisa atual.

\begin{tabular}{|c|c|c|c|c|}
\hline Inclinação & PESQUISA & REIS et al & ANDREWS & ZANELATO \\
\hline Incisivo central superior direito & $3,93^{\circ}$ & $-14,09^{\circ}$ & & \\
\hline Incisivo central superior esquerdo & $3,84^{\circ}$ & $-12,00^{\circ}$ & & $5,28^{0}$ \\
\hline
\end{tabular}


Para os incisivos centrais superiores direito e esquerdo, observaram-se valores médios de inclinação de $+3,93^{0}$ e $+3,84^{0}$ para os dentes 11 e 21 respectivamente neste estudo. Andrews (1972) observou valores médios de inclinação de $+6,11^{0}$ e Zanelato (2006) de $+5,28^{0}$. Já Reis et al (2008), encontraram valores de inclinação de $-14,09^{0}$ e $-12,00^{0}$ para os dentes 11 e 21 respectivamente.

Comparando-se os valores encontrados por Reis et al (2008) com aqueles presentes nesta pesquisa, observa-se a grande compensação dentária apresentada por este grupo de dentes. O tratamento compensatório é o protocolo ortodôntico adotado para a maioria dos casos na rotina clínica, justificando tais valores. Embora os valores denotem incisivos centrais bastante compensados, o ortodontista encontra, frequentemente, limitações para maiores compensações pelo prejuízo ósseo causado pela fissura. O mesmo achado é validos para os demais dentes do arco superior e influenciam diretamente a compensação do arco inferior, que deve engrenar-se perfeitamente com aquele.

Pôde-se observar, também, que os valores de inclinação máximo e mínimo foram bastante divergentes: $+13,20^{\circ}$ e $-7,80^{\circ}$ para o incisivo central direito; $+14,30^{\circ}$ e $-7,00^{\circ}$ para o incisivo central esquerdo. Esses valores podem ser conferidos na tabela 16 do tópico Resultados.

Um fator estético importante a ser observado na reabilitação dos pacientes é a relação existente entre a inclinação dos incisivos centrais superiores com os incisivos laterais e destes últimos com os caninos. Tanto Andrews (1989), em sua prescrição para classe I, II e como Capelozza Filho (2004), para prescrição padrão I, II e concordam que a diferença de inclinação entre os incisivos centrais e laterais deve ser de $4^{\circ}$, fazendo com que os incisivos centrais possuam um torque vestibular mais acentuado que os laterais. Essa diferença de valores na passagem dos incisivos centrais para os laterais é um fator de equilíbrio funcional e 
estético muito importante, uma vez que promove a manutenção da guia anterior e confere qualidade visual ao dente, semelhante àquela observada nas oclusões normais naturais.

Semelhante ao ocorrido com os grupos dos caninos e incisivos laterais superiores, os incisivos centrais superiores apresentaram simetria entre os lados direito e esquerdo do arco dentário, no que tange os valores médios totais de inclinação dispostos no quadro 9. No entanto, ao avaliarmos cada paciente individualmente, observa-se que os valores mais assimétricos de toda a amostra foram encontrados para este grupo de dentes (tabela 25), ainda que estatisticamente não significantes $(\mathrm{p}>0,05)$.

Tabela 25 - Valores médios de inclinação dos dentes 11 e 21 para cada paciente.

\begin{tabular}{ccccccccccc}
\hline \hline Paciente & $\# \mathbf{1}$ & \#2 & \#3 & \#4 & \#5 & \#6 & \#7 & \#8 & \#9 & \#10 \\
dente 11 & $-7,50^{\circ}$ & $+3,35^{\circ}$ & $-0,35^{\circ}$ & $+0,80^{\circ}$ & $+5,60^{\circ}$ & - & $+12,65^{\circ}$ & $+6,55^{\circ}$ & $+8,85^{\circ}$ & $+5,40^{\circ}$ \\
dente 21 & $-6,65^{\circ}$ & $+14,30^{\circ}$ & $+1,50^{\circ}$ & $-4,55^{\circ}$ & $+4,70^{\circ}$ & $+6,70^{\circ}$ & $+10,40^{\circ}$ & $+1,75^{\circ}$ & $+11,40^{\circ}$ & $-1,20^{\circ}$ \\
\hline \hline
\end{tabular}

----- Dente ausente

O paciente \#2 apresentou a maior discrepância entre os incisivos centrais superiores direito e esquerdo de toda a amostra e, clinicamente, essa assimetria pôde ser notada para a inclinação vestíbulo-lingual desses dentes, embora de significância bastante moderada. Por serem dentes adjacentes à fissura assim como os caninos superiores, aparentemente estão sujeitos a maior influência daquela do que os caninos. Estes últimos, presentes nos segmentos palatinos posteriores, apresentam suas raízes circundadas por maior quantidade óssea que os incisivos centrais, permitindo ao ortodontista maior controle na movimentação ortodôntica. Observou-se que os incisivos centrais apresentavam suas raízes circundadas por uma quantidade óssea bastante ínfima, especialmente nas regiões distal, vestibular e palatina. Mesmo nos casos em que o paciente foi submetido à cirurgia de enxerto ósseo alveolar (90\% da amostra), houve perdas ósseas das mais variadas formas ao redor das raízes dos incisivos centrais, sendo que o mesmo fenômeno não foi observado com a mesma amplitude ao redor 
das raízes dos caninos. Isso pode ser explicado pelo fato de que o protocolo ideal para a realização da cirurgia de enxerto ósseo alveolar do HRAC é imediatamente antes da irrupção dos caninos superiores no arco dentário, favorecendo a centralização das coroas dentárias dos caninos no rebordo alveolar e a condição periodontal de suas raízes. Segundo Trindade e Silva Filho (2007, p.173-98), após o enxerto ósseo o canino em irrupção mergulha no novo osso em direção ao plano oclusal, atravessando o osso enxertado, criando boa condição periodontal e adaptação anátomo-funcional. O mesmo não ocorre com os incisivos centrais superiores, já irrompidos na cavidade oral no momento da cirurgia de enxerto ósseo alveolar.

As perdas ósseas do novo osso enxertado são esperadas e ocorrem com maior magnitude nos casos em que o planejamento ortodôntico envolveu a colocação de implantes ou próteses para a reabilitação do espaço protético deixado pela ausência do incisivo lateral. Isso deve-se ao fator de que o enxerto é realizado por volta dos 10 anos de idade, enquanto que a reabilitação, seja com prótese ou implante, acontecerá ao término do tratamento ortodôntico ou ao término do crescimento corporal, por volta dos 18 anos. Esse tempo decorrido entre a cirurgia de enxerto ósseo e a finalização protética pode ter como resultado a perda do osso enxertado na região dos incisivos laterais pela ausência de função durante esse período. Três dos dez pacientes apresentavam espaços protéticos com perdas ósseas próximas às raízes dos incisivos centrais (Fig.30) e em especial um dos pacientes não foi submetido ao enxerto ósseo. 

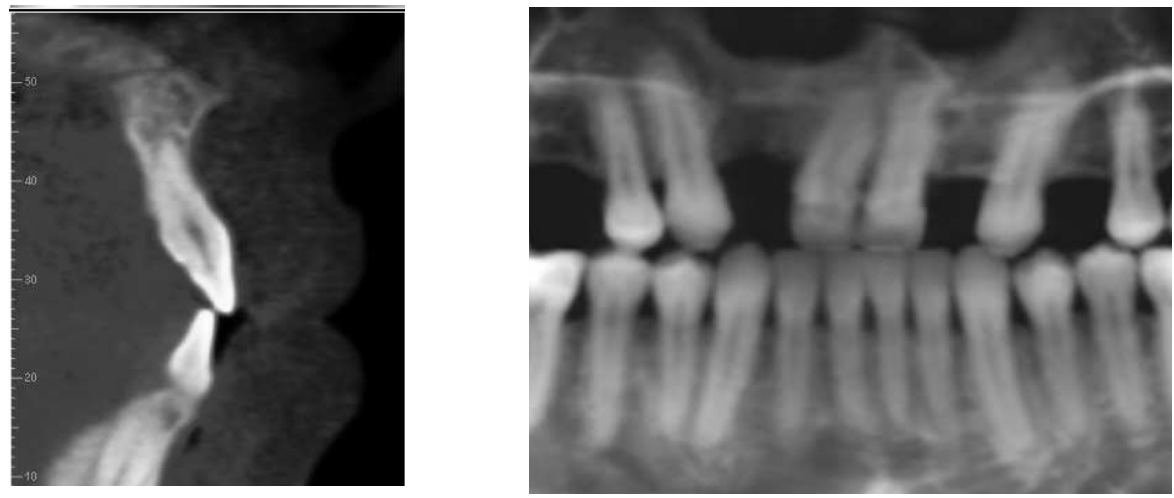

Figura 30 - Perda do enxerto ósseo adjacente ao espaço protético.

Os pacientes com maiores discrepâncias entre os valores de inclinação dos incisivos centrais superiores direito e esquerdo foram os pacientes \#2, 8, 9 e 10. Este último apresentou perda óssea distalmente à raiz do dente 21 , com fechamento do espaço deixado pela ausência do incisivo lateral pela movimentação mesial do canino adjacente, enquanto que os pacientes \#2 e 9 apresentaram perda do osso enxertado e presença de espaço protético na região dos dentes 12 e 22 . O paciente \#8 não foi submetido à cirurgia de enxerto ósseo alveolar.

Essa observação mostrou-se muito importante no que tange ao planejamento do tratamento ortodôntico dos pacientes com fissura bilateral na busca do tratamento ideal. Embora a reabilitação com implantes na região dos incisivos laterais superiores possa favorecer a estética, considerando que a movimentação do canino para o fechamento do espaço envolve a reanatomização de sua coroa, frequentemente de coloração mais amarelada que os incisivos centrais e laterais, a perda óssea, que ocorre de forma tridimensional, decorrente do tempo de espera para a realização dos implantes ou próteses nessa região, limita a movimentação dos incisivos centrais e prejudica a sua finalização e simetria no arco, conforme constatado neste trabalho. Isso deve ser ponderado no planejamento ortodôntico inicial de cada caso, individualmente.

Embora o ortodontista deva sempre se preocupar em finalizar o tratamento o mais próximo do ideal possível, sabe-se que na prática isso às vezes é limitado no que diz respeito 
a reabilitação dos pacientes fissurados, sendo a principal responsável por valores divergentes daqueles encontrados na literatura a grande variação presente na área da fissura. Como mencionado anteriormente, alguns casos são finalizados com caninos em classe II substituindo incisivos laterais ausentes; em outros há a presença de pré-caninos ou laterais mal-formados, e ainda há casos onde o enxerto não é realizado ou foi reabsorvido prejudicando o correto posicionamento dos dentes ao final do tratamento.

\section{Prescrição de bráquete}

Capelozza Filho et al (1999) sugerem a utilização de bráquetes com inclinação de $+7^{0}$ para os incisivos centrais, nos padrões I e II e de $+14^{0}$ para o padrão III. Andrews (1989) sugere a prescrição de bráquetes com $+7^{0}$ para classe I, $+2^{0}$ para a classe II e $+12^{0}$ para a classe III.

Os incisivos centrais apresentaram valores médios de inclinação de $+3,89^{0}$. Os valores médios dos incisivos centrais superiores, apesar de positivos, aproximaram-se apenas dos valores de inclinação da prescrição de Andrews para classe II $\left(+2^{0}\right)$.

Era de se esperar que os valores médios de inclinação dos dentes superiores se aproximassem dos valores da prescrição padrão III de Capelozza, uma vez que esse é o padrão predominante do paciente com fissura. Entretanto, isso foi verdade apenas para os caninos superiores. A grande variação encontrada, já discutida anteriormente, reflete a heterogeneidade da amostra, as limitações impostas ao tratamento ortodôntico pela presença ou não de enxerto ósseo alveolar e a qualidade desse enxerto ao longo do processo reabilitador.

\subsubsection{Caninos Inferiores}

Os dentes inferiores, de um modo geral, por não sofrerem influência direta da fissura, apresentaram valores menos discrepantes. No quadro abaixo seguem os valores médios de inclinação dos caninos inferiores, comparando-os com a literatura pertinente. 
Quadro 10 - Valores médios de inclinação dos dentes 33 e 43 nos artigos de Andrews (1972), Zanelato (2006), Reis et al (2008) e na pesquisa atual.

\begin{tabular}{|c|c|c:c:c|}
\hline Inclinação & PESQUISA & REIS et al & ANDREWS & ZANELATO \\
\hline canino inferior direito & $-5,42^{0}$ & $-13,10^{0}$ & & \\
\hline canino inferior esquerdo & $-5,26^{0}$ & $-12,93^{0}$ & $-12,73^{0}$ & $-10,13^{0}$ \\
\hline
\end{tabular}

Com relação aos valores de inclinação caninos inferiores, observou-se uma média de $5,42^{0}$ de inclinação para o dente 43 e de $-5,26^{0}$ para o dente 33 , sugerindo haver uma certa simetria entre os lados direito e esquerdo do arco dentário inferior. Andrews (1972) encontrou valores de inclinação de $-12,73^{0}$ em pacientes não-fissurados e Zanelato (2006) $-10,23^{0}$. Reis et al (2008) encontraram uma média de inclinação de $-13,10^{0}$ e de $-12,93^{0}$ para pacientes fissurados não tratados. Os valores máximo e mínimo observados para o dente 33 foram $+2,70^{\circ}$ e $-13,30^{\circ}$, respectivamente e para o dente 43 foram de $+3,20^{\circ}$ e $-13,80^{\circ}$.

Os resultados obtidos sugeriram uma inclinação lingual desses dentes e, apesar dos valores médios negativos, foram menores do que aqueles observados pelos autores em seus trabalhos (Andrews 1972; Reis 2008; Zanelato 2006). A causa mais provável para valores menores de inclinação dos caninos inferiores seria a manutenção da relação transversal interarcos pelo fato de que os caninos superiores apresentaram-se menos inclinados para palatina do que era de se esperar pelos valores da literatura.

Tabela 26 - Valores médios de inclinação dos dentes 33 e 43 para cada paciente.

\begin{tabular}{|c|c|c|c|c|c|c|c|c|c|c|}
\hline Paciente & \#1 & \#2 & \#3 & \#4 & \#5 & \#6 & \#7 & $\# 8$ & \#9 & $\# 10$ \\
\hline dente 33 & $-10,35^{0}$ & $-3,65^{0}$ & $+2,20^{\circ}$ & $-3,55^{0}$ & $-3,45^{0}$ & $-8,15^{0}$ & $-7,30^{\circ}$ & $-12,60^{0}$ & $-2,80^{0}$ & $-2,90^{\circ}$ \\
\hline dente 43 & $-8,25^{0}$ & $-2,20^{\circ}$ & $+2,85^{\circ}$ & $-5,35^{0}$ & $-4,00^{0}$ & $-8,45^{0}$ & $-8,00^{0}$ & $-13,25^{0}$ & $-4,25^{0}$ & $-3,25^{0}$ \\
\hline
\end{tabular}

Quando se comparam os valores de inclinação do canino inferior esquerdo com o direito, em um mesmo paciente e entre os pacientes da amostra, observa-se novamente uma 
grande variação nos valores médios de um paciente para outro (estatisticamente não significante $(\mathrm{p}>0,05))$, mas entre os lados direito e esquerdo, em um mesmo paciente, essa mesma variação não foi tão significativa em termos de simetria, especialmente quando se trata de simetria com significância clínica uma vez que o paciente compôs a amostra também pela qualidade do tratamento recebido. O paciente \#8 apresentou os valores mais negativos para este grupo de dentes, exatamente o mesmo que não recebeu enxerto ósseo alveolar no arco superior. Todos esses dados podem ser conferidos na tabela 26.

\section{Prescrição de Bráquetes}

Segundo Capelozza Filho et al (1999), os bráquetes para os caninos inferiores deveriam conter $-11^{0}$ de inclinação lingual para todas as prescrições, concordando com Andrews (1989). Esse valor seria ideal considerando o tratamento do paciente \#8, mas, para o restante da amostra, seria exageradamente acentuada para lingual, dificultando a acomodação da relação interarcos e da guia de desoclusão canina. É interessante pontuar que os autores mencionados anteriormente propuseram tais prescrições para tratamento de pacientes nãofissurados e que talvez outras pesquisas sejam necessárias para estabelecer se tal posicionamento do canino inferior, encontrado nesta amostra, se deu ao acaso ou se é uma das tantas variáveis peculiares ao tratamento dos pacientes com fissura. É importante que esta questão seja arrolada pois, talvez, permita o desenvolvimento de uma linha de bráquetes com prescrições mais próximas daquelas encontradas para o tratamento do paciente com fissura.

\subsubsection{Incisivos centrais e laterais inferiores}

É de se esperar que, ao final de qualquer tratamento ortodôntico, os incisivos inferiores apresentem o mesmo grau de inclinação, seja para vestibular ou para lingual. Portanto serão comparados juntos incisivos centrais e laterais. No caso dos pacientes com fissura bilateral, 
com protocolo de tratamento compensatório, normalmente os incisivos inferiores encontramse inclinados para lingual de modo a "compensar" a deficiência maxilar apresentada, garantindo uma boa relação interarcos. Segue abaixo os valores médios de inclinação para os incisivos centrais e laterais inferiores

Quadro 11 - Valores médios de inclinação dos dentes 32, 31, 41 e 42 nos artigos de Andrews (1972), Zanelato (2006), Reis et al (2008) e na pesquisa atual.

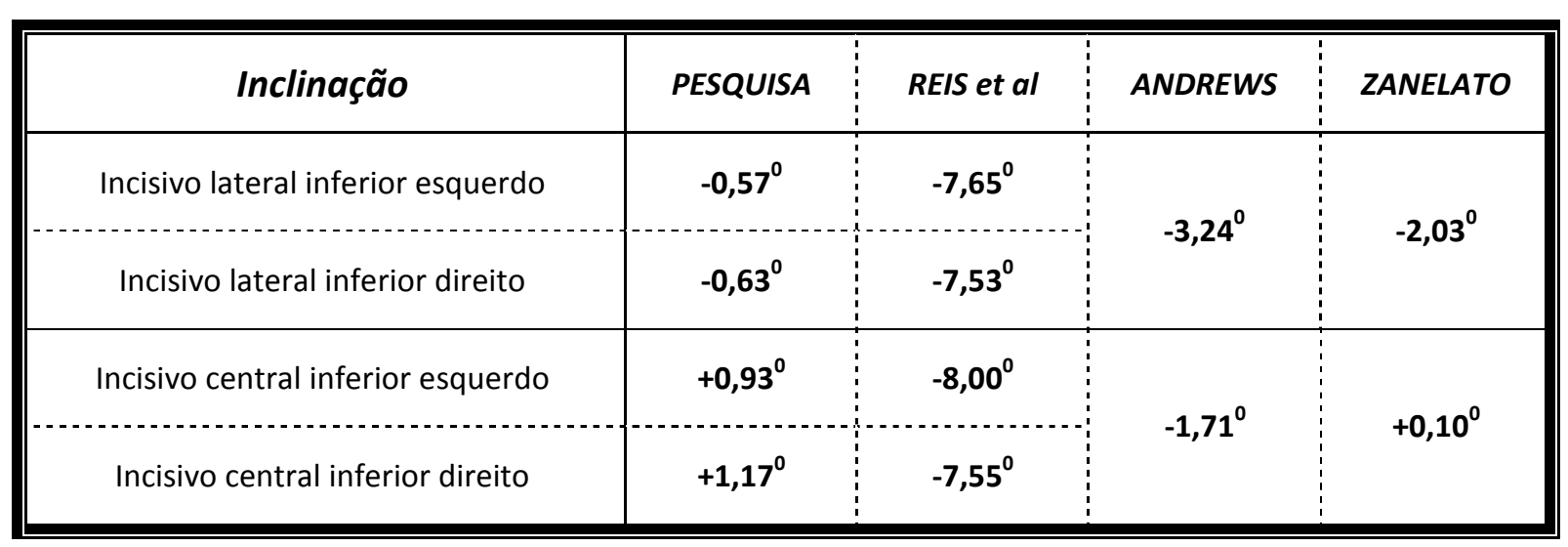

A média de inclinação para os incisivos centrais inferiores direito e esquerdo foi de $+1,17^{0}$ e $+0,93^{0}$ e para os incisivos laterais inferiores de $-0,63^{0}$ e $-0,57^{0}$ respectivamente. Observa-se que os valores, apesar de próximos, ficaram positivos para os incisivos centrais e negativos para os incisivos laterais e bastante simétricos quando comparados entre os grupos de dentes (incisivos laterais entre si e com os incisivos centrais e incisivos centrais entre si). Tanto para Andrews, como para Zanelato, os incisivos laterais estavam mais lingualizados que os incisivos centrais inferiores, semelhante ao que ocorreu neste estudo. Deve-se, ainda, levar em consideração que o exame tomográfico foi realizado no momento em que o paciente estava em fase de contenção pós-tratamento, período no qual algumas alterações sutis de posicionamento dentário ocorrem quando comparado com o momento em que o aparelho ortodôntico foi removido da boca do paciente. Provavelmente essa diferença observada na inclinação não foi clinicamente significante uma vez que um dos critérios para inclusão do paciente na amostra foi a finalização adequada. 
Os valores máximo e mínimo para o incisivo central direito foram de $+13,00^{0}$ e $-5,30^{0}$; para o incisivo central esquerdo, de $+12,30^{\circ} \mathrm{e}-7,10^{\circ}$, para o incisivo lateral direito foram de $+12,80^{\circ}$ e $-5,20^{0}$ e para o incisivo lateral esquerdo foram de $+12,00^{0} 3-12,90^{0}$.

Tabela 27 - Valores médios de inclinação dos dentes 32, 42, 31 e 41 para cada paciente.

\begin{tabular}{|c|c|c|c|c|c|c|c|c|c|c|}
\hline Paciente & $\# 1$ & \#2 & \#3 & $\# 4$ & \#5 & \#6 & \#7 & $\# 8$ & $\# 9$ & $\# 10$ \\
\hline dente 32 & $-12,45^{\circ}$ & $-2,40^{\circ}$ & $11,95^{\circ}$ & $2,05^{\circ}$ & $4,55^{\circ}$ & $-4,80^{\circ}$ & $-2,40^{\circ}$ & $-3,65^{\circ}$ & $-3,25^{\circ}$ & $-1,85^{\circ}$ \\
\hline dente 42 & $-4,80^{\circ}$ & $-2,80^{\circ}$ & $12,70^{\circ}$ & $0,65^{\circ}$ & $4,35^{\circ}$ & $-7,05^{0}$ & $-2,50^{\circ}$ & $-6,55^{0}$ & $1,15^{\circ}$ & $-1,40^{\circ}$ \\
\hline dente 31 & $-6,90^{\circ}$ & $-3,05^{0}$ & $11,95^{\circ}$ & $2,15^{\circ}$ & $9,05^{\circ}$ & $-2,05^{\circ}$ & $-1,55^{\circ}$ & $-2,25^{\circ}$ & $3,65^{\circ}$ & $-1,70^{\circ}$ \\
\hline dente 41 & $-4,65^{0}$ & $-3,40^{\circ}$ & $12,75^{\circ}$ & $-1,50^{\circ}$ & $9,40^{\circ}$ & $-1,40^{0}$ & $-1,55^{0}$ & $-2,45^{0}$ & $3,35^{\circ}$ & ----- \\
\hline
\end{tabular}

Quando se comparam os valores médios de inclinação dos incisivos centrais e laterais inferiores para um mesmo paciente e entre os pacientes observa-se que houve simetria na posição final destes dentes em, praticamente, todos os pacientes, exceto para os pacientes \#1,6 e 8. No paciente $\# 5$, apesar de haver diferença de $5^{0}$ na posição dos incisivos centrais, em relação aos laterais, clinicamente não houve prejuízo estético. O paciente \#3 apresentou os valores mais positivos para todos os incisivos inferiores, estando estes fortemente inclinados para vestibular. Este paciente foi submetido à cirurgia ortognática e, portanto seu tratamento ortodôntico foi conduzido de forma descompensatória previamente à cirurgia. Além do mais, o paciente é da raça indígena com protrusão do arco inferior. Em termos de significância estatística, nenhum desses grupos de dentes apresentaram-se estatisticamente significantes $(\mathrm{p}>0,05)$.

\section{Prescrição de Bráquetes}

Neste trabalho, os valores médios totais de inclinação dos incisivos inferiores foram próximos de zero, semelhantes aos valores sugeridos por Capelozza Filho (2004) para a prescrição padrão I ( $-1^{0}$ para os incisivos inferiores) e por Andrews para classe I $\left(-1^{0}\right.$ para os 
incisivos inferiores). Segundo o autor (Capelozza Filho, 2004), valores de inclinação e angulação próximos de zero são característicos dos pacientes padrão I conforme descritos nos parágrafos anteriores.

\subsubsection{Angulação}

O tratamento ortodôntico do paciente com fissura bilateral possui, na maioria dos casos, duas vertentes. Uma envolve a reabilitação através de um protocolo compensatório, normalmente característico do padrão III, proposto por Capelozza Filho (2004), e a outra vertente, por meio de um protocolo ortodôntico-cirúrgico buscando características do padrão I. O que define o caminho a seguir é a severidade da deformidade na relação intermaxilar.

Capelozza Filho e Cordeiro (2008) estabeleceram que, nos casos onde a correção do degrau sagital maxilo-mandibular ocorre por meio de um tratamento compensatório do padrão III, os caninos superiores devem apresentar-se fortemente angulados para a mesial e os incisivos superiores inclinados para a vestibular de modo a ocupar maior espaço no arco dentário superior. Entretanto, o inverso deve ocorrer no arco inferior, com caninos menos angulados e incisivos mais lingualizados, para permitir uma diminuição no perímetro do arco dentário. Já nos casos onde o protocolo seguido foi descompensatório, com correção da discrepância maxilo-mandibular por meio da cirurgia ortognática, o tratamento deve, ao final, buscar características de inclinação e angulação semelhantes àquelas encontradas nos padrões faciais I.

Essas peculiaridades no tratamento compensatório ou cirúrgico do padrão III é que permitem a correção da deformidade intermaxilar e das guias de desoclusão anteriores e canina.

Para embasamento da discussão, serão referenciados os valores médios de angulação encontrados pelos seguintes autores: Reis et al (2008), Normando et al (2008), Andrews 
(1972; 1989), Zanelato (2006), Capelozza Filho et al (1999), Capelozza Filho (2004) e Ramos e Bramante (1997). Ramos e Bramante (1997) descrevem, em seu livro, os valores de angulação do longo eixo dentário e, portanto, foram incluídos na discussão uma vez que este trabalho também avaliou a angulação formada entre o longo eixo dentário e uma perpendicular ao plano oclusal. Apesar de vários artigos, publicados na literatura, citarem a medição da angulação na panorâmica, todos utilizaram como referência o ângulo formado entre o longo eixo dentário e outros planos horizontais e consequentemente não puderam ser incluídos na comparação dos valores neste trabalho. Os demais artigos incluídos nesta pesquisa avaliaram a angulação formada entre o longo eixo coronário e uma perpendicular aos planos horizontais paralelos ao plano oclusal, tal como o plano de Andrews. Ainda que os valores de angulação do longo eixo dentário e coronário não sejam iguais (Andrews 1972), seus valores são bastante próximos e, portanto, esses artigos foram incluídos de modo a fornecer dados que auxiliem na elucidação deste tópico de discussão.

\subsubsection{Caninos Superiores}

Com relação à angulação dos dentes 13 e 23 , encontraram-se respectivamente os seguintes valores médios: $+8,60^{0} \mathrm{e}+11,17^{0}$. Andrews (1972), por sua vez, observou um valor médio de $+8,40^{\circ}$ para caninos superiores em pacientes não-fissurados, e Reis et al (2008) observaram valores médios de $+19,12^{0}$ para o lado direito e $+18,52^{0}$ para o lado esquerdo em pacientes fissurado não tratados. Zanelato (2006) encontrou um valor médio de $+7,13^{0}$, enquanto que Normando et al (2008) encontraram para classe I um valor médio de angulação de $+7,92^{0}$ para o dente 13 e de $+8,13^{0}$ para o dente 23. Para classe III encontraram respectivamente $+9,97^{0}$ e $+10,1^{0}$. Ramos e Bramante (1997) sugeriram, em seu livro, que a média de angulação para o canino superior, no seu longo eixo dentário, seria de $+6,00^{0}$. Todos esses dados podem ser conferidos no quadro 12 . 
Quadro 12 - Valores médios de angulação dos dentes 13 e 23 nos artigos de Andrews (1972), Zanelato (2006), Reis et al (2008), Normando et al (2008), no livro de Ramos e Bramante (1997) e na pesquisa atual.

\begin{tabular}{|c|c|c|c|c|c|c|c|}
\hline Angulação & PESQUISA & $\begin{array}{l}\text { REIS } \\
\text { et al }\end{array}$ & $\begin{array}{r}\text { NORA } \\
e\end{array}$ & $\begin{array}{l}\text { ANDO } \\
\text { al }\end{array}$ & ANDREWS & ZANELATO & $\begin{array}{c}\text { RAMOS e } \\
\text { BRAMANTE }\end{array}$ \\
\hline & & & cl.I & cl.III & \multirow{3}{*}{$+8,40^{\circ}$} & \multirow{3}{*}{$+7,13^{0}$} & \multirow{3}{*}{$+6,00^{\circ}$} \\
\hline canino superior direito & $+8,60^{\circ}$ & $+19,12^{0}$ & $+7,92^{0}$ & $+9,97^{0}$ & & & \\
\hline canino superior esquerdo & $+12,31^{0}$ & $+18,52^{\circ}$ & $+8,13^{0}$ & $+10,1^{0}$ & & & \\
\hline
\end{tabular}

Os valores médios obtidos, neste estudo, para o canino superior direito foram muito próximos daqueles observados por Andrews (1972), sendo que para o canino esquerdo o valor médio aproximou-se mais dos achados de Normando et al (2008) para a classe III.

No caso dos pacientes fissurados, a restrição ao crescimento maxilar imposta pela queiloplastia primária leva, ao longo do crescimento, a um padrão facial característico dos pacientes padrão III. O tratamento ortodôntico compensatório, nesses pacientes, por sua vez, segue também um protocolo de tratamento dos pacientes padrão III desde o seu início. Muitas vezes se faz necessária a melhoria da relação sagital interarcos através da tração reversa da maxila, concomitantemente à expansão rápida numa fase mais precoce, na época da dentadura mista, de modo a minimizar os efeitos colaterais das cirurgias primárias no crescimento maxilar. Além disso, durante o tratamento ortodôntico compensatório, é comum o uso de elásticos de classe III para a correção da relação ântero-posterior dos arcos dentários. Somando-se os efeitos da tração reversa e dos elásticos de classe III, é de se esperar uma angulação acentuada, para mesial, dos caninos superiores. Reis et al (2008) levantaram algumas hipóteses para justificar essa angulação acentuada: a primeira seria o fato dos caninos estarem adjacentes à fissura e não haver tecido ósseo à mesial desses dentes, fazendo com que suas raízes busquem uma posição mais distal favorecendo uma maior angulação mesial da coroa dentária. Além disso, a ausência de contato mesial ao canino, pela agenesia do incisivo 
lateral, favoreceria uma migração mesial da coroa dentária e, por último, a deficiência alveolar vertical, causada pela ascendência dos segmentos alveolares, faria com que o canino se apresentasse mais angulado em sua base.

Neste estudo, a diferença das médias entre os lados direito e esquerdo foi de $3,71^{\circ}$, sugerindo uma maior angulação do canino esquerdo em relação ao seu homólogo no lado direito. No entanto, clinicamente essa diferença geralmente não foi perceptível em termos de simetria, e o paciente que mais contribuiu para essa diferença, na média, foi o \#8, o qual não recebeu enxerto ósseo alveolar. Somando-se a esse paciente, os pacientes \#1, 3, 5 e 10 contribuíram para os valores assimétricos entre ambos os lados do arco dentário, sendo que desses, os de \#1, 3 e 10 possuíam primeiros pré-molares movimentados para ocupar a posição dos caninos superiores. A partir dessa observação, pode-se questionar que talvez os prémolares, nessa condição, não adquiram a angulação idealmente prescrita aos caninos substituídos.

Novamente observou-se uma grande variação entre os valores de angulação máximo e mínimo dos dentes 13 e $23\left(+15,60^{\circ}\right.$ e $+0,80^{\circ} ;+16,60^{\circ}$ e $+5,00^{\circ}$ respectivamente $)$, o que pode ser atribuído, além das hipóteses levantadas acima (Reis et al 2008), ao fato de o primeiro prémolar ter sido movimentado para o lugar do canino em quatro dos dez casos avaliados.

Tabela 28 - Valores médios de Angulação dos dentes 13 e 23 para cada paciente.

\begin{tabular}{|c|c|c|c|c|c|c|c|c|c|c|}
\hline Paciente & $\# 1$ & $\# 2$ & \#3 & $\# 4$ & $\# 5$ & \#6 & $\# 7$ & $\# 8$ & $\# 9$ & $\# 10$ \\
\hline dente 13 & $+2,80^{\circ}$ & $+12,80^{\circ}$ & $+7,70^{\circ}$ & $+15,10^{\circ}$ & $+12,45^{\circ}$ & $+15,45^{\circ}$ & $+9,60^{\circ}$ & $+0,85^{\circ}$ & $+6,15^{\circ}$ & $+3,10^{\circ}$ \\
\hline dente 23 & $+7,90^{\circ}$ & $+12,90^{\circ}$ & $+11,00^{\circ}$ & $+16,00^{\circ}$ & $+15,95^{\circ}$ & $+16,95^{\circ}$ & $+8,40^{\circ}$ & $+16,55^{\circ}$ & ----- & $+5,15^{\circ}$ \\
\hline
\end{tabular}

Comparando os resultados encontrados entre cada paciente da amostra e observando os valores do canino direito em relação ao esquerdo, para um mesmo paciente (tabela 28), constata-se a grande variação da amostra, porém estatisticamente não significante ( $p>0,05)$. 
De um modo geral, praticamente todos os pacientes apresentaram valores de angulação bastante divergentes entre ambos os lados do arco dentário, sendo que o paciente \#8 (não tratado com enxerto ósseo alveolar) obteve os valores mais díspares. A causa para valores tão divergentes atribuídos a esse paciente é exatamente a limitação de movimentação da raiz dos caninos, no sentido mésio-distal, pela ausência óssea a mesial desses dentes, especialmente para o dente 23.

Uma comparação interessante de se fazer é em relação aos pacientes tratados com protocolos ortodôntico-compensatório e ortodôntico-cirúrgico (descompensatório). Excetuando-se o paciente \#8, pelas limitações de tratamento descritas no parágrafo acima, os pacientes \#1, 3 e 7 apresentaram valores de angulação mais baixos que o restante da amostra. Esses pacientes receberam tratamento ortodôntico-cirúrgico, enquanto que os demais foram tratados de maneira compensatória e a eles foram atribuídos os maiores valores de angulação. Esse achado é de grande importância, no início do tratamento, na escolha dos bráquetes que mais se aproximem do protocolo estabelecido e faz toda a diferença, em termos de posição final dos dentes, uma vez que para cada protocolo as metas a serem atingidas durante e ao final do tratamento são diferentes em termos de angulação canina. Essas diferenças serão melhor discutidas no subtópico "prescrição de bráquetes" abaixo.

\section{Prescrição de Bráquetes}

Andrews (1989) sugere uma angulação de $+11^{0}$ para os caninos superiores, independentemente do padrão facial ou protocolo de tratamento. Capelozza Filho et al (1999) apontam que uma angulação de $+11^{0}$ é excessiva para pacientes padrão I e II e ideal para o tratamento compensatório de pacientes padrão III. Os autores sugerem $+8^{0}$ para a prescrição I, $+5^{0}$ para a prescrição II e $+11^{0}$ para a prescrição III.

De acordo com os resultados obtidos neste estudo, e para maior compreensão, dividiremos os pacientes de acordo com o protocolo de tratamento realizado: 
- Ortodôntico-cirúrgico (descompensatório): pacientes \#1, 3 e 7

- Compensatório do padrão III: pacientes \#2, 4, 5, 6, 8 e 10.

Os pacientes cujo protocolo de tratamento foi ortodôntico-cirúrgico apresentaram, ao final, um valor médio de angulação de $+7,9^{0}$. Esse valor aproxima-se muito da prescrição I proposta por Capelozza et al (1999). Segundo Reis et al (2008), esses caninos apresentam uma angulação excessivamente positiva ao início do tratamento. Para a execução do protocolo descompensatório, instituído a esses pacientes, é necessário que os caninos percam essa angulação excessiva de modo a diminuir o perímetro do arco dentário superior e prepará-los para a correção da relação interarcos na cirurgia ortognática. Se a correção dessa relação maxilo-mandibular se der na cirurgia, as coroas dos caninos superiores não precisam estar fortemente anguladas para mesial ao final do tratamento e devem apresentar angulações próximas daquelas observadas por Andrews (1972) nas "Seis chaves da oclusão normal”, cujo valor médio é de $+8,40^{\circ}$. Assim, em termos de angulação, a prescrição I de Capelozza é a que mais de aproxima da meta a ser atingida para esses dentes ao término do processo reabilitador.

Já nos pacientes, cujo protocolo de tratamento envolveu a correção da relação intermaxilar através da compensação dentária, os caninos superiores apresentaram uma média de angulação de $+11,49^{0}$, muito próxima do valor de angulação embutido na prescrição III sugerido por Capelozza et al (1999). No tratamento desses pacientes, é interessante que a coroa dos caninos superiores esteja fortemente inclinada para mesial e ocupem mais espaço no arco dentário ao final do tratamento, de modo a corrigir a discrepância maxilo-mandilar através da compensação dentária conforme protocolo estabelecido por Capelozza Filho (2004) para o padrão III. Normado et al (2008) encontraram valores médios de angulação dos caninos superiores nas classes III (quadro 12) muito semelhantes aos achados neste estudo, reafirmando a necessidade de que sejam utilizados bráquetes que contenham angulações 
próximas desses valores. É o caso, por exemplo, da prescrição padrão de Andrews (1989) e da prescrição III de Capelozza (2004) cujo valor de angulação é de $+11^{0}$. A utilização de bráquetes com essa angulação favoreceria a correção da relação intermaxilar e a obtenção da guia canina de desoclusão de modo mais rápido e objetivo, visando a atingir a meta estabelecida inicialmente.

\subsubsection{Incisivos laterais superiores}

Os incisivos laterais superiores, como já descrito anteriormente, quando presentes, apresentam as mais variadas formas de coroa e raiz e posição de irrupção na arcada. Esses dentes compõem a pré-maxila juntamente com os incisivos centrais superiores e são os mais afetados pelo rompimento da continuidade do rebordo alveolar na presença da fissura lábiopalatina. A agenesia desse grupo de dentes é a variante mais comum nas fissuras com envolvimento do rebordo alveolar juntamente com a presença de um supranumerário à mesial dos caninos superiores e, portanto, assim chamado de pré-canino.

Várias são as possibilidades concernentes ao tratamento do paciente com fissura bilateral:

a) $\mathrm{Na}$ agenesia do incisivo lateral, o ortodontista pode:

-decidir pela colocação de implantes e, portanto, na manutenção do espaço protético;

- fechamento do espaço através da mesialização dos dentes do segmento posterior;

- aproveitamento do pré-canino transformando-o em lateral, quando as condições são favoráveis. 
b) Na presença do incisivo lateral: reanatomização de sua forma quando esta for uma possibilidade de tratamento viável, dependendo das condições periodontais do dente.

Todas essas possibilidades terão implicação direta na angulação final do dente, embora o "modelo ideal" de finalização, a partir do trabalho das "Seis chaves da oclusão normal" (Andrews 1972), seja a meta a ser alcançada em qualquer tratamento ortodôntico.

Partindo dessa premissa e considerando todas as particularidades e limitações do tratamento ortodôntico, na presença de um arco dentário acometido pela fissura, pôde-se observar a grande variação em relação a este dente na amostra selecionada, a qual será melhor explorada mais adiante, na análise individual de cada caso.

Quadro 13 - Valores médios de angulação dos dentes 12 e 22 nos artigos de Andrews (1972), Zanelato (2006), Reis et al (2008), no livro Ramos e Bramante (1997) e na pesquisa atual.

\begin{tabular}{|c|c|c|c|c|c|}
\hline Angulação & PESQUISA & $\begin{array}{l}\text { REIS } \\
\text { et al }\end{array}$ & ANDREWS & ZANELATO & $\begin{array}{c}\text { RAMOS e } \\
\text { BRAMANTE }\end{array}$ \\
\hline Incisivo lateral superior direito & $+7,66^{0}$ & ------ & $+8,04^{0}$ & $+6,19^{0}$ & $+5^{0}$ \\
\hline Incisivo lateral superior esquerdo & $+9,11^{0}$ & ------ & & & \\
\hline
\end{tabular}

Em termos gerais de angulação, observou-se neste estudo que os valores foram maiores para o incisivo lateral esquerdo $\left(+9,11^{0}\right)$ em comparação com o direito $\left(+7,66^{0}\right)$, porém, muito próximos do valor médio de $+8,04^{0}$ observado por Andrews (1972). Zanelato encontrou um valor médio de angulação de $+6,19^{0}$, enquanto que Ramos e Bramante descreveram que esse dente está situado na cavidade oral com angulação média de $+5^{0}$ (Quadro 13).

O lado esquerdo apresentou incisivos laterais um pouco mais angulados para mesial que o lado direito, com uma diferença nas médias de $1,45^{\circ}$, seguindo um padrão semelhante, 
observado para os caninos superiores em suas posições mésio-distal. Essa é uma observação interessante, pois, apesar da ligeira assimetria entre os lados opostos do arco dentário, muito mais em termos numéricos do que em qualidade de tratamento, esse padrão manteve-se constante na passagem dos caninos para os incisivos laterais superiores.

Os valores máximo e mínimo variaram consideravelmente:

- Incisivo lateral direito: $+14,70^{\circ} \mathrm{e}+1,20^{\circ}$;

- Incisivo lateral esquerdo: $+24,00^{0} \mathrm{e}+1,10^{0}$.

Da amostra, como um todo, apenas em cinco pacientes as medidas dos incisivos laterais superiores puderam ser aferidas. Do restante da amostra, três pacientes apresentavam espaço protético tanto no 12 como no 22 , e outros dois apresentavam incisivos laterais com coroas protéticas, sendo excluídos da medição, pelo motivo já explicado anteriormente.

Tabela 29 - Valores médios de Angulação dos dentes 12 e 22 para cada paciente.

\begin{tabular}{|c|c|c|c|c|c|c|c|c|c|c|}
\hline Paciente & $\# 1$ & $\# 2$ & \#3 & $\# 4$ & $\# 5$ & \#6 & $\# 7$ & $\# 8$ & $\# 9$ & $\# 10$ \\
\hline dente 12 & $+8,30^{\circ}$ & (-- & $+4,50^{\circ}$ & ---- & $+1,65^{0}$ & $+14,55^{0}$ & ----- & ---- & ----- & $+9,35^{\circ}$ \\
\hline dente 22 & $+9,00^{\circ}$ & ----- & $+3,75^{\circ}$ & ----- & $+1,10^{\circ}$ & $+23,70^{\circ}$ & ----- & ---- & ---- & $+8,00^{\circ}$ \\
\hline
\end{tabular}

Os valores mais díspares de todos os grupos de dentes ocorreram para esta amostra quando a comparação é feita entre os sujeitos da pesquisa, embora, de um modo geral, tenha havido certa simetria entre os incisivos laterais direito e esquerdo para cada paciente, exceto o de \#6. Os valores encontrados para os pacientes \#1 e 10 aproximam-se daqueles descritos por Andrews (1972); os valores do paciente \#3 são semelhantes aos de Ramos e Bramante (1997) e os pacientes \#5 e 6 tiveram os valores mais divergentes.

Nos pacientes \#1, 3, 6 e 10, o espaço deixado pelo incisivo lateral foi fechado pela movimentação mesial dos caninos superiores, enquanto que o paciente \#5 apresentou incisivos laterais com coroas mais hígidas. 


\section{Prescrição de bráquetes}

Andrews (1972) e Capelozza Filho (2004) concordam que a angulação embutida no bráquete do incisivo lateral deve ser de $+9^{0}$. Neste trabalho, o valor médio de angulação do incisivo lateral superior $\left(+8,38^{0}\right)$ aproximou-se muito do valor de $+9^{0}$ proposto pelos autores mencionados acima. Além do mais, Capelozza Filho pontua que "a angulação pode ser manipulada na colagem direta. A superfície plana do dente e do bráquete em torno do ponto EV nos incisivos permite isso sem que nenhuma outra prescrição do bráquete seja afetada. Este fato propicia individualizar cada caso, com intenção de ocupar mais ou menos espaço e tornar o nivelamento mais ou menos protrusivo" de acordo com a intenção de correção proposta para o caso.

\subsubsection{Incisivos centrais superiores}

Os incisivos centrais superiores, assim como caninos e incisivos laterais, sofrem alterações no seu trajeto irruptivo e podem apresentar alterações de forma associada, tais como hipoplasia do esmalte e dentina, coroas disformes etc. A quebra da solução de continuidade do rebordo alveolar, de variadas amplitudes, altera o trajeto irruptivo dos incisivos centrais (Reis et al 2008), fazendo com que suas raízes "busquem" posições de contra-angulação no sentido mésio-distal, voltadas em direção ao plano sagital mediano, de modo a "fugir" das áreas com ausência óssea principalmente à distal desses dentes.

Neste estudo foram encontrados valores médios de angulação para o incisivo central direito de $+0,77^{0}$ e, para o incisivo central esquerdo, de $+1,26^{0}$. Reis et al (2008) encontraram em pacientes fissurados, não tratados ortodonticamente, os seguintes valores médios para os respectivos dentes: $-4,67^{0}$ e $-2,88^{0}$. Andrews (1972), em sua amostra de 120 modelos de gesso de oclusão normais não tratadas, encontrou um valor médio de $+3,59^{0}$ para os incisivo centrais superiores e Zanelato (2006) encontrou, para uma amostra brasileira, $+2,21^{0}$. Ramos e 
Bramante (1997) descrevem que os incisivos centrais superiores situam-se na cavidade bucal com uma angulação de $+3^{0}$ em seu longo eixo. Segue abaixo o quadro 14 com os valores encontrados na literatura e neste trabalho.

Quadro 14 - Valores médios de angulação dos dentes 11 e 21 nos artigos de Andrews (1972), Zanelato (2006), Reis et al (2008), no livro Ramos e Bramante (1997) e na pesquisa atual.

\begin{tabular}{|c|c|c|c|c|c|}
\hline Angulação & PESQUISA & $\begin{array}{l}\text { REIS } \\
\text { et al }\end{array}$ & ANDREWS & ZANELATO & $\begin{array}{c}\text { RAMOS e } \\
\text { BRAMANTE }\end{array}$ \\
\hline Incisivo central superior direito & $0,77^{0}$ & $-4,67^{0}$ & \multirow{3}{*}{$+3,59^{\circ}$} & \multirow{3}{*}{$+2,21^{0}$} & \multirow{3}{*}{$+3^{0}$} \\
\hline & & & & & \\
\hline Incisivo central superior esquerdo & $+1,26^{0}$ & $-2,88^{0}$ & & & \\
\hline
\end{tabular}

Os valores de angulação máximo e mínimo para o incisivo central direito foram respectivamente $+7,00^{\circ}$ e $-10,00^{\circ}$, e para o incisivo central esquerdo, de $+9,40^{\circ}$ e $-15,40^{\circ}$.

A análise individual dos valores obtidos para os incisivos centrais de cada sujeito da amostra e a comparação desses valores entre os pacientes permitem uma melhor compreensão de como esses dentes estavam posicionados ao final do tratamento (tabela 30).

Tabela 30 - Valores médios de Angulação dos dentes 11 e 21 para cada paciente.

\begin{tabular}{|c|c|c|c|c|c|c|c|c|c|c|}
\hline Paciente & $\# 1$ & $\# 2$ & \#3 & $\# 4$ & $\# 5$ & $\# 6$ & $\# 7$ & $\# 8$ & $\# 9$ & $\# 10$ \\
\hline dente 11 & $-0,55^{0}$ & $-5,40^{0}$ & $+2,60^{\circ}$ & $+3,50^{\circ}$ & $+2,35^{0}$ & ----- & $+4,60^{\circ}$ & $-9,75^{0}$ & $+2,80^{\circ}$ & $+6,80^{\circ}$ \\
\hline dente 21 & $+0,50^{\circ}$ & $+9,00^{\circ}$ & $+2,30^{\circ}$ & $-3,30^{\circ}$ & $+0,35^{\circ}$ & $+6,75^{\circ}$ & $-3,30^{\circ}$ & $+9,50^{\circ}$ & $+5,85^{\circ}$ & $-15,05^{\circ}$ \\
\hline
\end{tabular}

----- Dente ausente

Para os incisivos centrais, assim como para os demais grupos de dentes avaliados, apesar dos valores médios de angulação bastante próximos (quadro 14), houve grande variação na posição mésio-distal entre os lados direito e esquerdo de um mesmo paciente, exceto no paciente \#3. Comparando os valores de angulação entre os sujeitos da pesquisa, a variação encontrada não foi estatisticamente significante $\left(p>0,05^{0}\right) . \mathrm{O}$ ponto mais relevante, 
entretanto, está na relação de angulação/contra-angulação dos incisivos centrais em, praticamente, todos os pacientes. Explicando melhor, enquanto um dos incisivos centrais estava angulado, o seu homólogo estava contra-angulado e com valores muito semelhantes. Por exemplo, o paciente \#1 apresentou o dente 11 com $-0,55^{0}$ (contra-angulado) e o dente 21 com $+0,50^{\circ}$ (angulado). Esse padrão se repetiu para os pacientes \#2, 4, 7, 8 e 10, representando $60 \%$ da amostra. A hipótese mais provável para esse achado é a manutenção da angulação/contra-angulação radicular presente, anteriormente à cirurgia de enxerto ósseo alveolar, devido à escassez de osso nessa região e à limitação da movimentação ortodôntica mesmo após a cirurgia de enxerto pela presença de áreas com reabsorção óssea.

\section{Prescrição de bráquetes}

Novamente Andrews (1972) e Capelozza Filho (2004) concordam que a angulação embutida no bráquete do incisivo central deve ser de $+5^{0}$. Os autores também concordam com a diferença de $4^{\circ}$ de angulação na passagem dos incisivos centrais para os incisivos laterais superiores, para todas as prescrições, sendo que os incisivos centrais encontram-se menos angulados para a mesial do que os laterais. Da mesma forma como foi descrito para a inclinação, essa diferença confere estética e equilíbrio funcional auxiliando, também, na manutenção dos pontos de contato anteriores.

Neste trabalho, a diferença na passagem da angulação dos incisivos centrais para os laterais foi de aproximadamente $+8^{0}$, bem acima daquela preconizada por Andrews (1989) e Capelozza Filho et al (1999) de $+4^{0}$, no que tange à angulação desses dentes. O valor médio de angulação do incisivo central superior foi de $+1,02^{0}$, denotando raízes pouco anguladas muito provavelmente devido à condição óssea que as cercavam pelos mesmos aspectos mencionados anteriormente para os caninos e incisivos laterais em relação às áreas do rebordo alveolar. 


\subsubsection{Incisivos centrais e laterais inferiores}

No que tange ao tratamento ortodôntico dos pacientes fissurados, é interessante que se promova uma diminuição no perímetro do arco dentário inferior de modo a acomodá-lo com oclusão do arco superior, geralmente atrésico. Para isso, os dentes anteriores inferiores necessitam ocupar menos espaço no arco à custa de uma menor angulação de suas coroas e raízes (Capelozza Filho e Cordeiro 2008).

Quadro 15 - Valores médios de angulação dos dentes 32, 31, 41 e 42 nos artigos de Andrews (1972), Zanelato (2006), Reis et al (2008), no livro Ramos e Bramante (1997) e na pesquisa atual.

\begin{tabular}{|c|c|c|c|c|c|}
\hline Inclinação & PESQUISA & REIS et al & ANDREWS & ZANELATO & $\begin{array}{c}\text { RAMOS e } \\
\text { BRAMANTE }\end{array}$ \\
\hline Incisivo lateral inferior esquerdo & $+3,97^{0}$ & $-1,77^{0}$ & $+0,38^{0}$ & $-0,58^{0}$ & $0^{0}$ \\
\hline Incisivo central inferior esquerdo & $+1,57^{0}$ & $-0,53^{0}$ & $+0,53^{0}$ & $+0,03^{0}$ & $0^{0}$ \\
\hline
\end{tabular}

Com relação à angulação, os incisivos centrais inferiores apresentaram uma média de $+1,57^{0}$ e $+1,35^{0}$ para os lados esquerdo e direito, respectivamente, e os incisivos laterais inferiores de $+3,97^{0} \mathrm{e}+2,29^{0}$. Em termos numéricos, os incisivos centrais mostraram-se mais simétricos em suas posições do que os incisivos laterais, neste estudo. Idealmente, esse grupo de dentes (incisivos centrais e laterais inferiores) deveriam apresentar o mesmo valor de angulação (Andrews 1972). Andrews observou valores médios de $+0,53^{0}$ para os incisivos centrais inferiores e $+0,38^{0}$ para os incisivos laterais inferiores, Reis et al (2008), em pacientes fissurados não-tratados, encontraram valores médios de $-1,77^{0}$ para o dente $32,-0,80^{0+}$ para o dente $42,-0,53^{0}$ para o dente 31 e $-0,64^{0}$ para o dente 41 . Zanelato (2006) encontrou um valor médio de $-0,58^{0}$ para os incisivos laterais e de $+0,03^{0}$ para os incisivos centrais. Ramos e 
Bramante (1997) descrevem que esses dentes situam-se na arcada dentária com uma angulação de $0^{0}$.

Os valores máximo e mínimo dos incisivos inferiores foram respectivamente:

- Dente $32:+12,40^{0}$ e $-2,60^{\circ}$;

- Dente 31: $+5,50^{0}$ e $-4,80^{0}$;

- Dente $41:+8,40^{0}$ e $-4,30^{\circ}$;

- Dente $42:+7,70^{0}$ e $-2,00^{0}$.

Na tabela 31 é possível verificar os valores médios de angulação dos incisivos inferiores para cada paciente. A comparação feita entre os pacientes da pesquisa mostra ter havido diferenças no posicionamento dos incisivos inferiores, porém em menor magnitude que para os grupos anteriores. Embora essa variação esteja presente, ela não foi estatisticamente significante $(\mathrm{p}>0,05)$. O paciente \#5 apresentou os valores mais elevados para a angulação dos incisivos inferiores.

Tabela 31 - Valores médios de angulação dos dentes 32, 42, 31 e 41 para cada paciente.

\begin{tabular}{|c|c|c|c|c|c|c|c|c|c|c|}
\hline Paciente & $\# 1$ & $\# 2$ & \#3 & $\# 4$ & \#5 & $\# 6$ & $\# 7$ & \#8 & $\# 9$ & $\# 10$ \\
\hline dente 32 & $+3,80$ & $+3,60$ & $+4,00$ & $+0,50$ & $+12,40$ & $-2,60$ & $+2,70$ & $+3,90$ & $+4,05$ & $+7,30$ \\
\hline dente 42 & $-2,00$ & $+2,40$ & $+3,40$ & $+0,70$ & $+7,70$ & $-1,40$ & $+3,25$ & 1,20 & $+5,25$ & $+4,75$ \\
\hline dente 31 & $+3,20$ & $+3,25$ & $-4,65$ & $+4,50$ & $+5,30$ & $-3,15$ & $+0,55$ & $+0,10$ & $+3,90$ & $+2,65$ \\
\hline dente 41 & $-4,10$ & $-0,95$ & $+4,05$ & $-1,55$ & $+8,15$ & $+3,25$ & $+0,30$ & $-0,55$ & $+3,50$ & ----- \\
\hline
\end{tabular}

\section{Prescrição de Bráquetes}

Capelozza Filho (2004) sugeriu utilizar bráquetes com angulação de $2^{0}$ para prescrição I e II e $0^{0}$ para prescrição III. Andrews (1972) sugeriu bráquetes que contenham $+2^{0}$ de angulação para todas as classes. Neste estudo, os valores médios de angulação ficaram mais próximos da prescrição I e II de Capelozza Filho e da prescrição de Andrews. 


\subsubsection{Caninos inferiores}

Assim como para os incisivos inferiores, os caninos inferiores estão menos angulados para a mesial, de modo a ocupar menos espaço no arco, permitindo uma diminuição no perímetro do arco dentário inferior e sua acomodação com o arco superior (Capelozza Filho e Cordeiro, 2008).

Os valores médios de angulação para os caninos inferiores podem ser conferidos no quadro 16.

Quadro 16 - Valores médios de angulação dos dentes 33 e 43 nos artigos de Andrews (1972), Zanelato (2006), Reis et al (2008), Normando et al (2008), no livro Ramos e Bramante (1997) e na pesquisa atual.

\begin{tabular}{|c|c|c|c|c|c|c|c|}
\hline Angulação & PESQUISA & $\begin{array}{l}\text { REIS } \\
\text { et al }\end{array}$ & $\begin{array}{r}\text { NORA } \\
e\end{array}$ & $\begin{array}{l}\text { NDO } \\
\text { al }\end{array}$ & ANDREWS & ZANELATO & $\begin{array}{c}\text { RAMOS e } \\
\text { BRAMANTE }\end{array}$ \\
\hline & & & cl.I & cl.III & \multirow{3}{*}{$+2,48^{\circ}$} & \multirow{3}{*}{$+2,43^{\circ}$} & \multirow{3}{*}{$+3,00^{\circ}$} \\
\hline canino inferior direito & $+5,51^{0}$ & $-1,83^{0}$ & $+3,78^{\circ}$ & $1,67^{0}$ & & & \\
\hline canino inferior esquerdo & $+7,18^{0}$ & $-2,00^{\circ}$ & $+3,27^{0}$ & $2,78^{0}$ & & & \\
\hline
\end{tabular}

Neste trabalho, os valores médios de angulação dos caninos inferiores direito e esquerdo foram, respectivamente, $+5,51^{0} \mathrm{e}+7,18^{0}$. Embora o canino esquerdo tenha se mostrado mais angulado que o seu homólogo direito, a diferença entre as médias foi de $1,67^{0}$. Estes valores não foram clinicamente e estatisticamente significantes $(\mathrm{p}>0,05)$.

Andrews (1972) e Zanelato (2006) encontraram respectivamente $+2,48^{0}$ e $+2,43^{0}$ de angulação para esses dentes. Reis et al (2008) encontraram $-1,83^{0}$ para o dente 43 e $-2,00^{0}$ para o dente 33, em pacientes com fissura bilateral, anteriormente ao tratamento ortodôntico. Ramos e Bramante (1997) descreveram que esses dentes situam-se na cavidade bucal com uma angulação de $+3,00^{0}$ em relação ao seu longo eixo. Normando et al (2008) encontraram 
valores de angulação de $+3,78^{0}$ para o dente 43 e de $++3,27^{0}$ para o dente 43 , em indivíduos com relação oclusal de classe I e, para os pacientes com relação oclusal de classe III, o autor encontrou os seguintes valores para os respectivos dentes $-2,78^{0} \mathrm{e}-1,67^{0}$.

Os valores médios de angulação encontrados nesta pesquisa estavam muito acima daqueles encontrados na literatura para esse grupo de dentes.

Tabela 32 - Valores médios de angulação dos dentes 33 e 43 para cada paciente.

\begin{tabular}{lllllllllll}
\hline \hline Paciente & $\# \mathbf{1}$ & \#2 & \#3 & \#4 & \#5 & \#6 & \#7 & \#8 & \#9 & \#10 \\
\hdashline dente 33 & $+5,85$ & $+8,80$ & $+8,65$ & $+2,75$ & $+11,05$ & $+6,60$ & $+6,25$ & $+8,65$ & $+4,75$ & $+8,45$ \\
dente 43 & $+0,50$ & $+8,45$ & $+7,75$ & $+1,20$ & $+10,00$ & $+5,45$ & $+6,70$ & $+3,95$ & $+5,45$ & $+5,65$ \\
\hline \hline
\end{tabular}

De uma maneira geral, houve simetria no posicionamente dos caninos inferiores para a maioria dos pacientes da amostra (tabela 32), exceto nos pacientes \#1, 8 e 10. O paciente \#1 foi submetido a cirurgia ortognática, o \#8 não recebeu enxerto ósseo no arco superior e o \#10 apresentou ausência de um incisivo inferior, com aumento da angulação dos dentes anteriores inferiores (caninos e incisivos) para fechamento do espaço.

A comparação dos valores de angulação entre os pacientes da amostra mostrou haver diferenças no posicionamento dos caninos inferiores de um paciente para outro, mas esses valores não foram estatisticamente significantes $(\mathrm{p}>0,05)$.

No que tange ao tratamento dos pacientes fissurados, era de se esperar que os valores médios de angulação estivessem mais próximos dos valores do padrão III (Capelozza Filho, 2004) do que do padrão I e II. Entretanto, neste estudo, foi observado o inverso e isso pode ser atribuído ao fato de que três dos dez pacientes avaliados (30\%) não foram tratados compensatoriamente e sim com tratamento descompensatório para correção a ortodônticacirúrgica (cirurgia ortognática). Desses três pacientes, dois tiveram apenas a maxila operada; o outro, maxila e mandíbula. 


\section{Prescrição de Bráquete}

Capelozza Filho (2004) sugerem a utilização de bráquetes com $5^{0}$ de angulação para os caninos inferiores no tratamento compensatório das más-oclusões do padrão I e II, e de $0^{0}$ para as más-oclusões do padrão III. Andrews sugere a utilização de bráquetes com $+5^{0}$ para todas as classes.

Observa-se que os resultados obtidos neste trabalho aproximam-se mais dos valores de angulação da prescrição I e II do que dos valores de padrão III para a angulação dos caninos inferiores, quando era de se esperar o inverso, conforme discutido no subtópico acima.

\subsection{AVALIAÇÃO MORFOLÓGICA DAS ESTRUTURAS DENTÁRIAS}

Nos pacientes selecionados para este trabalho, pôde-se avaliar a qualidade do osso alveolar e a relação que as raízes mantêm entre si e com o periodonto de suporte, achados esses descritos abaixo:

1. Observou-se que, praticamente, todos os dentes superiores apresentaram uma tábua óssea vestibular extremamente fina e muitas vezes presente apenas no terço apical das raízes (Fig. 31).

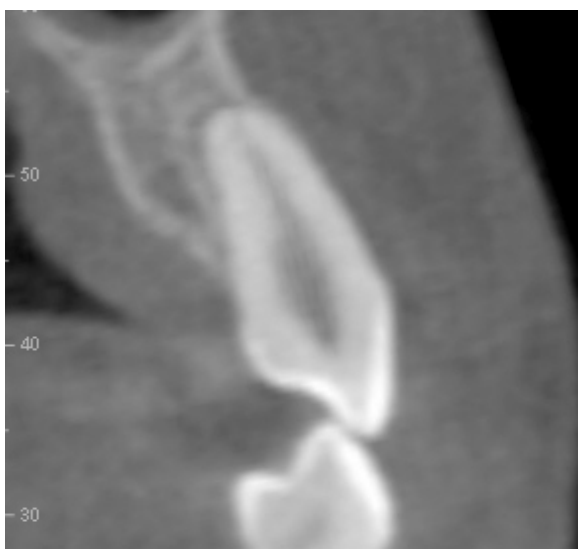

Figura 31 - Relação da raiz do canino superior com as tábuas ósseas vestibular e palatina. 
2. A tábua óssea palatina apresentou uma espessura maior para quase todos os dentes superiores avaliados, mas em alguns poucos casos estava presente somente até o terço apical na região palatina dos incisivos superiores (Fig. 32).

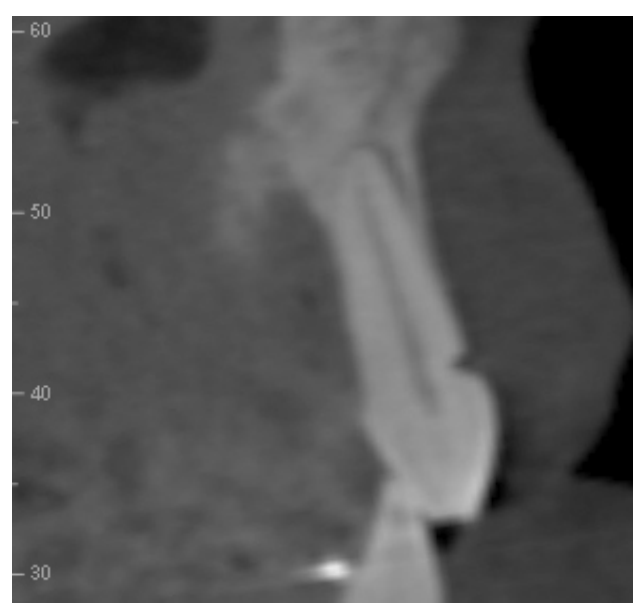

Figura 32 - Relação da raiz do incisivo central superior com as tábuas ósseas vestibular e palatina.

3. É impressionante a relação que as raízes dos incisivos e caninos inferiores mantiveram com as tábuas ósseas vestibular e lingual. Elas praticamente não existiam ou eram extremamente finas e, muitas vezes, presentes somente no terço apical das raízes. Provavelmente os dentes estavam sendo suportados apenas pelo periósteo (uma membrana que reveste o osso interna e externamente) muito embora seja baixo o contraste entre tecido duro e mole. (Fig. 33). 

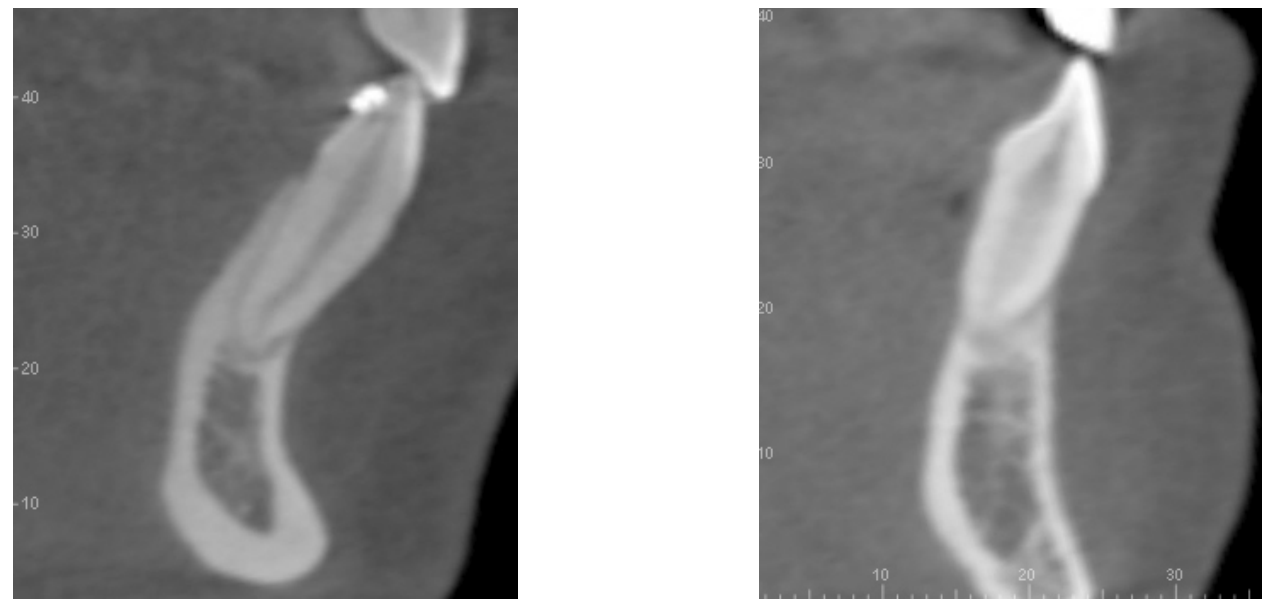

Figura 33 - Relação da raiz dos dentes inferiores com as tábuas ósseas vestibular e lingual.

4. Dois pacientes apresentaram um alto grau de reabsorção radicular nos incisivos superiores e inferiores (Fig. 34).
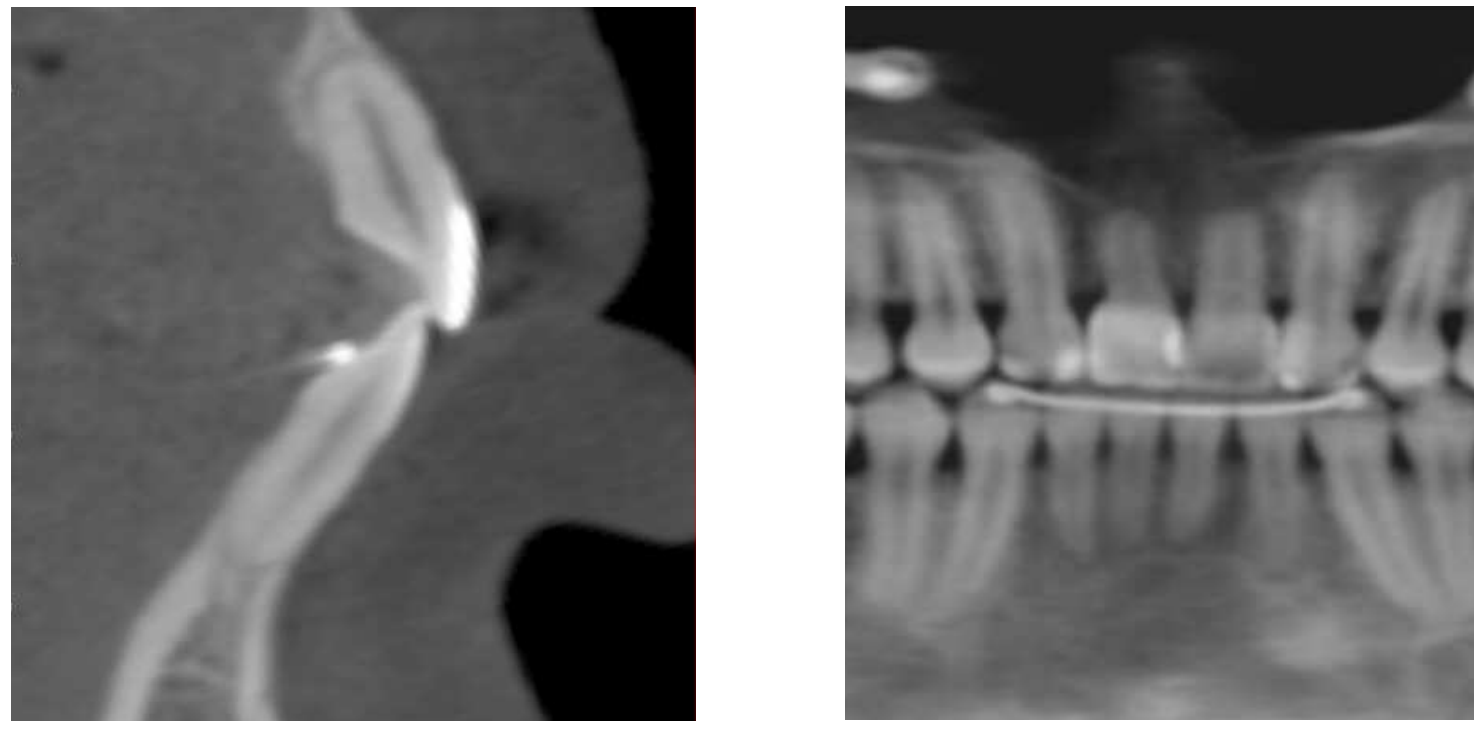

Figura 34 - Reabsorção radicular nos incisivos superiores e inferiores.

5. A panorâmica apresentou uma imagem de qualidade excelente. Nela pôde-se observar o posicionamento radicular e a presença de terceiros molares inclusos, e avaliar as áreas de enxerto ósseo. Alguns pacientes apresentaram perda em altura do osso na área 
do enxerto, fazendo com que os dentes adjacentes à fissura não tivessem suporte ósseo nas faces radiculares voltadas para a região da fissura (Fig. 35).

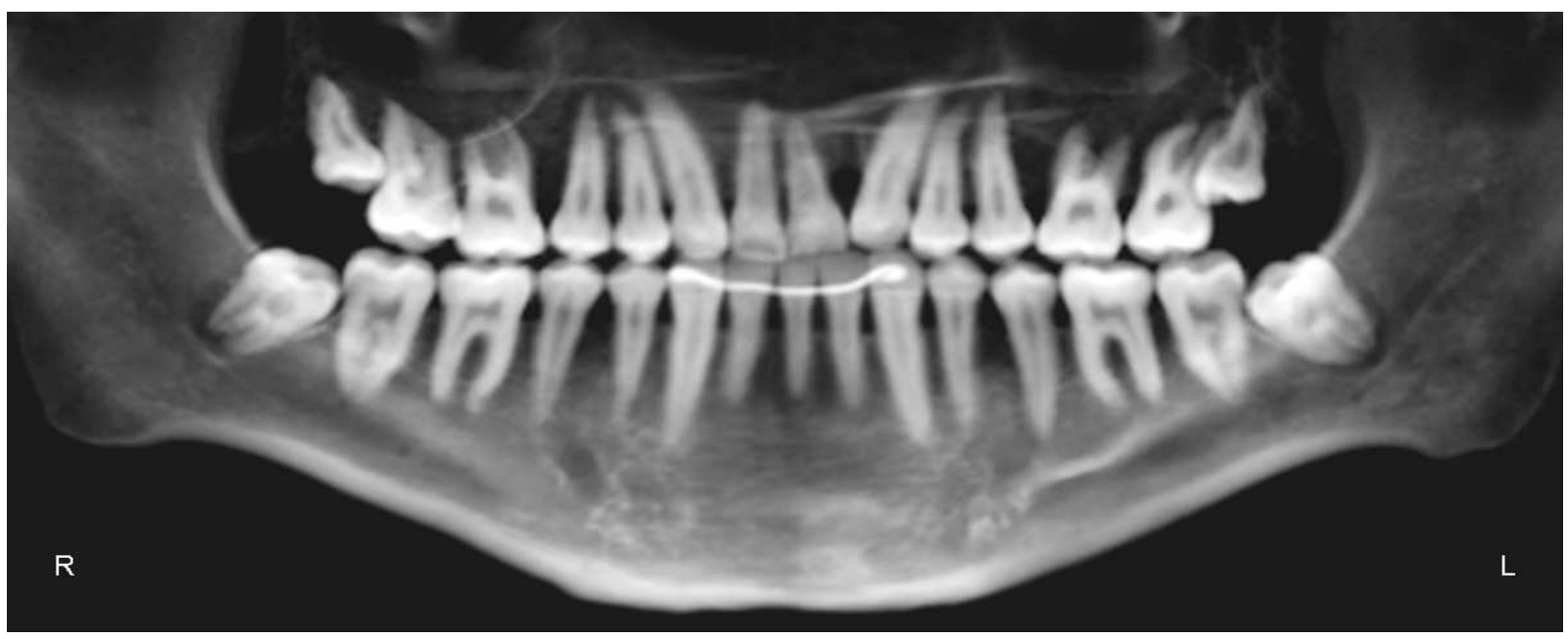

Figura 35 - Qualidade da imagem panorâmica.

6. Alguns pacientes apresentaram reabsorção óssea horizontal generalizada, em especial no arco superior (Fig. 36).

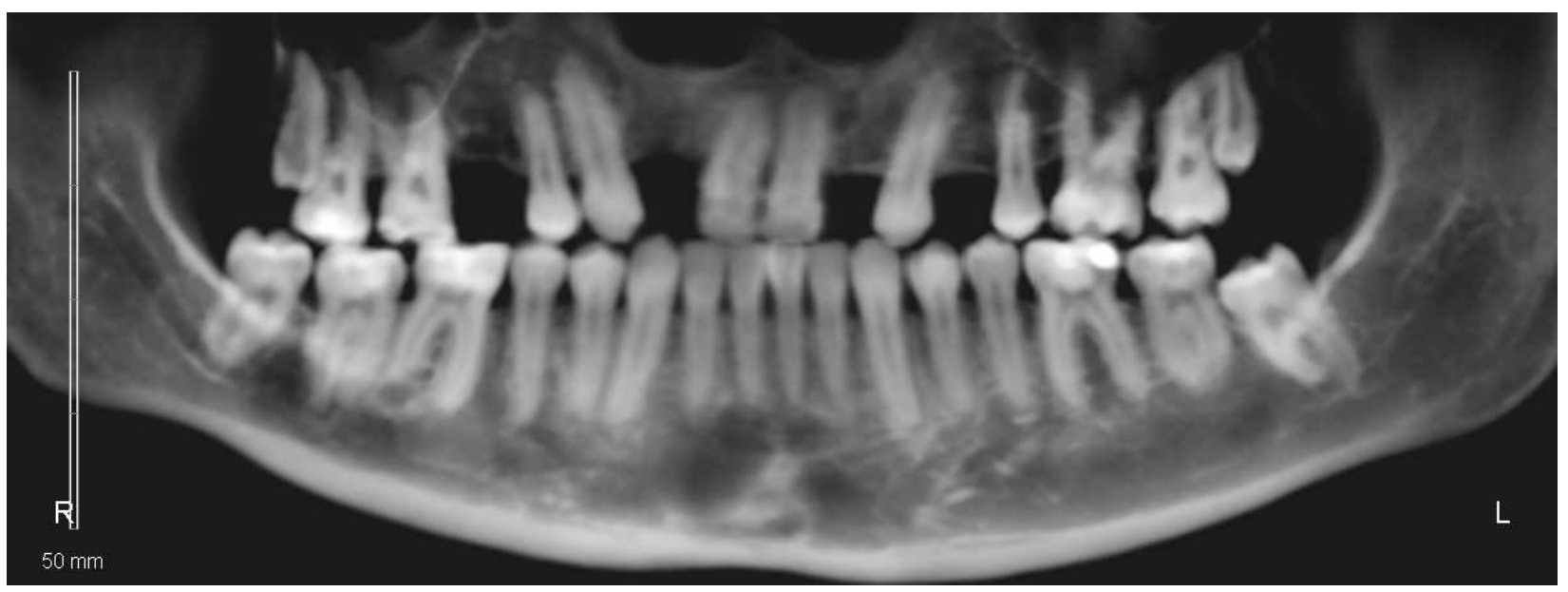

Figura 36 - Reabsorção óssea horizontal.

7. Em alguns casos, as raízes dos dentes inferiores estavam bem centralizadas na base óssea denotando a qualidade do tratamento executado (Fig. 37). 


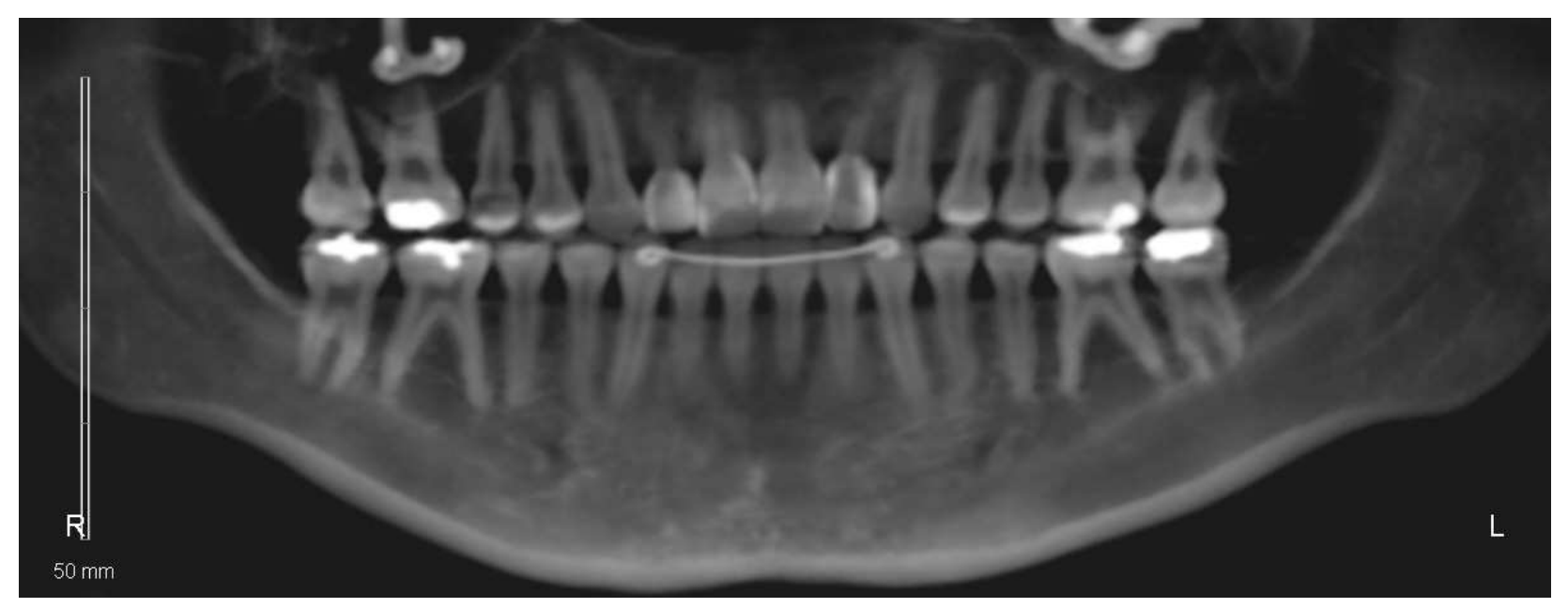

Figura 37 - Centralização das raízes dos incisivos inferiores.

8. Em um dos pacientes não havia a presença de enxerto ósseo reconstruindo o defeito anatômico da fissura, e as raízes dos incisivos centrais não apresentavam suporte ósseo em suas faces voltadas para a fissura (Fig. 38a, 38b e 39).
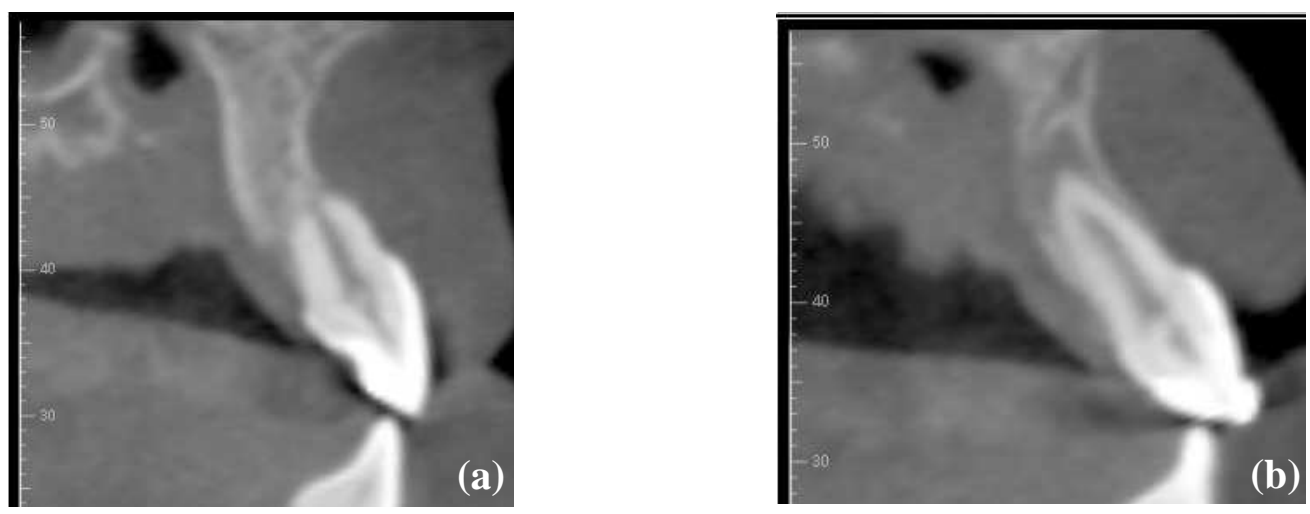

Figura 38 - Corte parassagital dos incisivos centrais superiores direito (a) e esquerdo (b). 


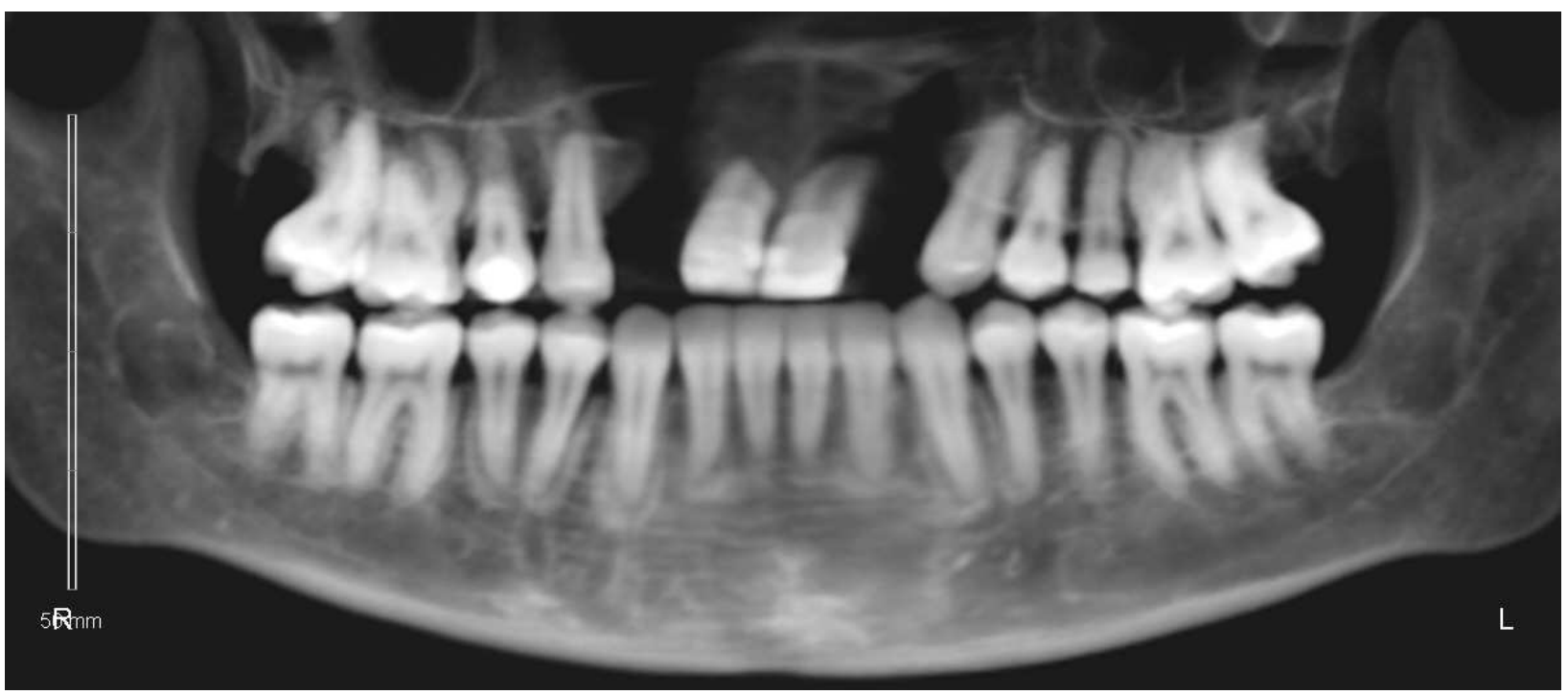

Figura 39 - Panorâmica de um paciente com presença do defeito ósseo alveolar bilateral.

9. Um paciente apresentou reabsorção vertical do enxerto ósseo alveolar bilateral na face distal das raízes dos incisivos centrais superiores (Fig. 40, 41a e 41b).

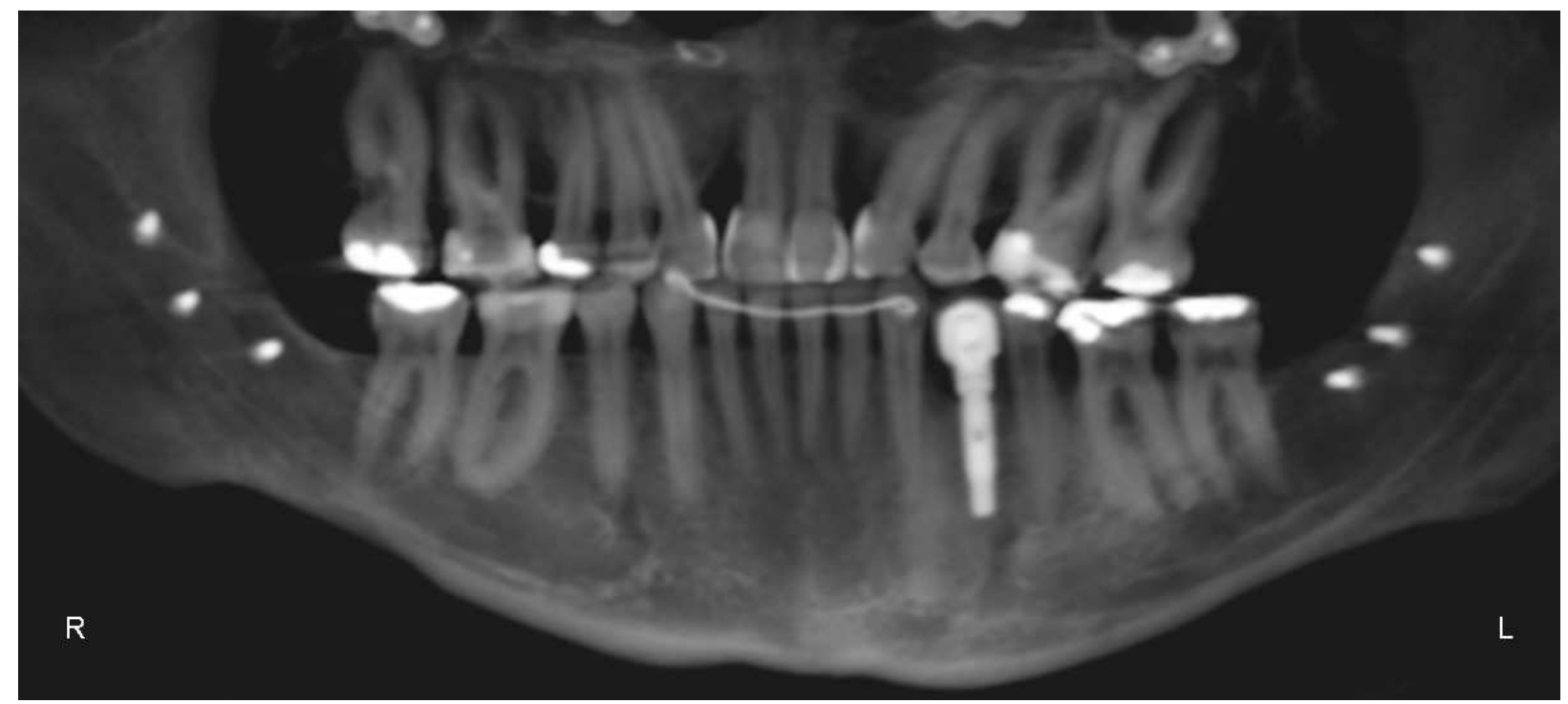

Figura 40 - Panorâmica de um paciente com reabsorção óssea bilateral na área do enxerto. 

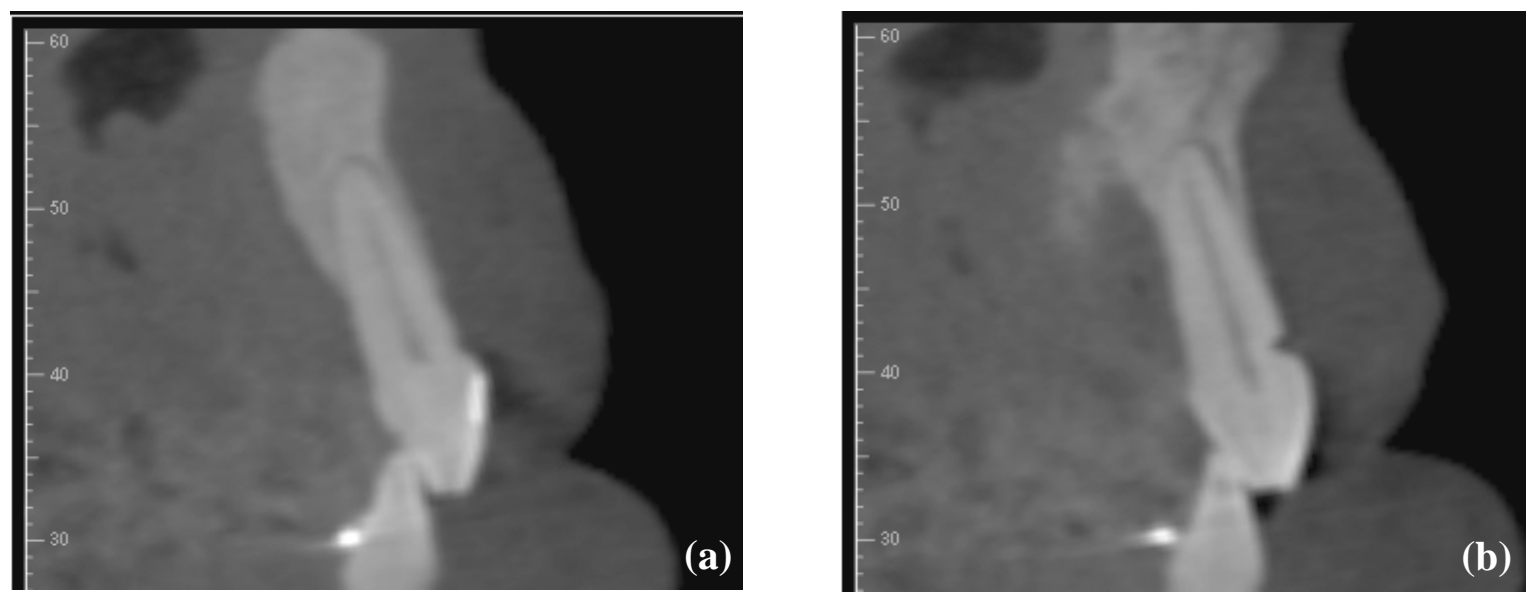

Figura 41 - Cortes parassagitais dos incisivos centrais superiores direito (a) e esquerdo (b).

Todos os achados descritos acima eram antes muito difíceis de serem visualizados nas radiografias convencionais, ou até mesmo impossíveis, seja pela qualidade das imagens das radiografias panorâmicas e laterais da face ou pelo tipo de corte (parassagital). Imaginava-se que esses achados pudessem estar acontecendo, mas era algo virtual até então, pois os métodos de avaliação disponíveis geravam imagens muito limitadas quanto à qualidade. A visualização dente a dente, em cortes parassagitais (cortes que permitem a visualização da relação das raízes com as tábuas ósseas vestibular e lingual), era impossível de ser obtida com as radiografias convencionais. Assim, pode-se dizer que nunca, na historia da odontologia, foi possível utilizar imagens com tanta qualidade, nitidez e detalhes como se pode hoje através da tomografia computadorizada e, o que mais impressiona, é a forma de visualização tridimensional de todas as estruturas anatômicas bem como suas relações entre si em tempo e tamanho reais. Talvez isso faça com que a odontologia, e em especial a Ortodontia, possa repensar muitos de seus protocolos de tratamento.

Algumas dificuldades ou limitações foram observadas na aplicação do método. Durante a mensuração da inclinação, houve a necessidade de se trabalhar com imagens ampliadas no software de edição de imagem, Adobe Photoshop, de modo a conseguir visualizar melhor o ponto EV e a superfície em que a reta que passa por EV tangencia a face 
vestibular. Entretanto, imagens ampliadas perdem um pouco da sua resolução. Com relação à angulação, a dificuldade encontrada foi na determinação do longo eixo em dentes com raízes tortas ou com dilacerações. Padronizou-se determinar o longo eixo até o ponto em que a raiz começava a apresentar um desvio ou uma dilaceração.

Por fim, uma amostra maior e mais homogênea em vários aspectos como padrão facial, etnia, tipo de má-oclusão e tratamento realizado seria necessária, em novos projetos de pesquisa, permitindo a utilização de valores médios de inclinação e angulação e compará-los àqueles presentes na literatura. 

CONCLUSÕES 



\section{CONCLUSÕES}

\section{Avaliação qualitativa do método:}

a) Esta nova metodologia mostrou-se bastante precisa e reproduzível para a mensuração das inclinações e angulações dentárias.

\section{Avaliação quantitativa do método:}

a) Os valores mais divergentes em relação, aos valores encontrados na literatura para oclusão normal, foram observados para o arco superior mostrando a importância da fissura no posicionamento dos mesmos.

b) $\mathrm{O}$ arco inferior se mostrou mais uniforme e com valores mais simétricos, denotando uma menor interferência da fissura.

\section{Avaliação morfológica do método:}

a) Este exame permitiu a visualização real da relação entre as raízes dentárias com o osso alveolar que as suportam.

b) Permitiu também a visualização do efeito do tratamento ortodôntico nas raízes dentárias e no osso alveolar de suporte.

c) Pode-se utilizar este método no planejamento ortodôntico para a seleção de um bráquete, para cada dente, que mais se aproxime da meta de tratamento idealizada. 



\section{REFERÊNCIAS}





\section{REFERÊNCIAS}

Andrews LF. The Straight-Wire appliance - Origin, Controversy,Commentary. J Clin Orthod.1976;10(2):99-114.

Andrews LF. The Straight-Wire appliance - Explained and Compared. J Clin Orthod.1976;10(3):174-95.

Andrews LF The Straight-Wire appliance - Case Histories: Nonextraction.J Clin Orthod.1976;10(4):282-303.

Andrews LF. The Straight-Wire appliance - Extraction Brackets and"Classification of Treatment". J Clin Orthod.1976;10(5):360-79.

Andrews LF. Straight wire: o conceito e o aparelho. San Diego: L. A. Wells; 1989.

Capelozza Filho L, Silva Filho OG, Ozawa TO, Cavassan AO. Individualização de bráquetes na técnica straight-wire: revisão de conceitos e sugestão de indicações para uso. Rev Dental Press Ortodon Ortop Maxilar 1999; 4:87-106.

Capelozza Filho L. Diagnóstico em Ortodontia. Maringá: Dental Press Editora; 2004.

Capelozza Filho L, Fattori L, Maltagliati LA. Um novo método para avaliar as inclinações dentárias utilizando a tomografia computadorizada. Rev Dental Press Ortodon Ortop Maxilar 2005; 10:23-9.

Capelozza Filho L, Cordeiro AS. Influência da angulação dos dentes anteriores no perímetro do arco superior[homepage na internet]. Abzil 3M [atualizada em 28 de março de 2008; acessado em 02 de junho de 2009] Disponível: http://multimedia.mmm.com/mws/ mediawebserver.dyn?6666660Zjcf6lVs6EVs66SRDJCOrrrrQ-.

Cohnen M, Kemper J, Mobes O, Pawelzik J, Modder U. Radiation doses in dental radiology. Eur Radiol 2002;12:634-7.

Firoosnia H, Golimbu CN, Rafii M, Rauschning W, Weinreb JC. MRI and CT of the musculoskeletal system. St. Louis: Mosby Year Book;1992.

Fleiss JL. The design and analysis of clinical experiments. New York: John Wiley \& Sons; 1986. 
Garib DG, Raymundo Jr R, Raymundo MV, Raymundo DV, Ferreira SN. Tomografia computadorizada de feixe cônico (Cone beam): entendendo este novo método de diagnóstico por imagem com promissora aplicabilidade na Ortodontia. Rev Dental Press Ortodon Ortop Maxilar.2007;12(2):139-56.

Graber TM, Vanarsdall Junior RL. Ortodontia: princípios e técnicas atuais. 2 ed. Rio de Janeiro: Guanabara Koogan;1996.

Geraedts CTM, Borstap WA, Groenewoud JMM, Stoenlinga PJW. Long-term evaluation of bilateral cleft lip and palate patients after early secondary closure and premaxilla repositioning. Int J Oral Maxillofac Surg. 2007;36(9):788-96.

Guedes IVC, Gondim PPC, Cimões R. Angulações e inclinações dentárias em pacientes com má oclusão de classe. Int J Dent of Recife. 2007, 6(1):7-11.

Hatcher M, Aboudara CL. Diagnosis goes digital. Am J Orthod Dentofacial Orthop. 2004; $125: 512-5$

Handelman CS. The anterior alveolus: its importance in limiting orthodontic treatment and its influence on the occurrence of iatrogenic sequelae. Angle Orthodontist. 1996;66(2):95-110.

Holberg C, Steinhäuser S, Geis P, Rudzki-Janson I. Cone-Beam Computed Tomography in Orthodontics: Benefits and Limitations. J Orofac Orthop 2005;66:434-44.

Houston WJB. The analysis of errors in orthodontics measurements. Am J Orthod Dentofacial Orthop 1983; 83: 382-90.

Jacobson A. Radiographic cephalometry: from basic to videoimaging. Illinois: Quintessence; 1995.

Manual de informações técnicas i-Cat [homepage na internet]. Pensilvânia: Imaging Sciences International;[atualizada em 22 de abril de 2009; acesso em 07 de junho de 2009]. Disponível:http;//www.imagingsciences.com.

Korbmacher H, Barbel HN, Schollchen M, Heiland M. Value of Two Cone-beam Computed Tomography Systems from an Orthodontic Point of View. J Orofac Orthop 2007; 68: 278-89.

Lascala CA, Panella J, Marques MM. Analysis of the accuracy of linear measurements obtained by cone beam computed tomography (CBCT- NewTom). Dentomaxillof Radiol 2004; 33:291-4. 
Mah JK, Danforth RA, Bumann A, Hatcher D. Radiation absorved in maxillofacial imaging with a new dental computed tomography device. Oral Surg Oral Med Oral Pathol Oral Radiol Endod 2003; 96:508-13.

Mussing E, Wortche R, Lux C. Indications for digital volume tomography in orthodontics. J Orofac Orthop 2005; 66: 241-9.

Normando ADC, Azevedo LR, Torres TB. Angulação dos Caninos em Indivíduos Portadores de Má Oclusão de Classe I e Classe III- Análise comparativa através de um novo método utilizando imagens digitalizadas [homepage na internet]. Abzil 3M [atualizada em 15 de maio de 2008; acesso em 02 de junho de 2009]. Disponível: http://multimedia.mmm.com/mws/ mediawebserver.dyn?6666660Zjcf61Vs6EVs66SrVvCOrrrrQ-.

Orban B (1957) apud Andrews LF. Straight wire: o conceito e o aparelho. San Diego: L. A. Wells; 1989.

Peck JL et al. Mesiodistal Root Angulation Using Panoramic and Cone Beam CT. Angle Orthod. 2007;77(2): 206-213.

Reis ACM et al. Avaliação da angulação e inclinação dos elementos dentários em pacientes adultos jovens portadores de fissura transforame incisivo bilateral $\mathrm{R}$ Dental Press Ortodon Ortop Facial.2008;13(1):113-123.

Roth RH. The Straight-Wire Appliance 17 years late. J Clin Orthod.1987 21(9):632-42.

Scarfe WC, Farman, AG, Sukovic P. Clinical Applications of Cone-Beam Computed Tomography in Dental Practice. J Can Dent Assoc 2006; 72: 75-80.

Saitovitch H. Cem anos da descoberta dos raios-x: caracterização estrutural de sólidos. Rev Bras Ens Física.1995; 17(3) 203-8.

Schulze D, Heiland M, Schmelzle R, Rother UJ. Diagnostic possibilities of cone-beam computed tomography in the facial skeleton. Int Cong Ser 2004,1268:1179-83.

Silva Filho O G et al. Craniofacial morphology in adult patients with unoperated complete bilateral cleft lip and palate. Cleft Palate Craniofac J. 1998;35(2):111-9.

Silva Filho O G et al. Influence of lip repair on craniofacial morphology of patients with complete bilateral cleft lip and palate. Cleft Palate Craniofac J. 2003;40(2):144-53. 
Silva Filho $\mathrm{O} G$ et al. Função canino desempenhada pelo pré-molar. Rev. Dent. Press Ortodon. Ortop. Facial. 2006;11(3):32-40.

Subtelny JD. Orthodontic treatment on cleft lip and palate birth to adulthood. Angle Orthod. 1966;36(4):273-92.

Sukovic P. Cone beam computed tomography in craniofacial imaging. Orthod Craniofacial Res 2003; 6(Suppl.1):31-6.

Trindade IEK, Silva Filho OG. Fissuras Labiopalatinas: Uma abordagem interdisciplinar.In: Silva Filho OG. Crescimento facial. São Paulo: Livraria Editora Santos, 2007. p.173-98.

Tsiklakis K, Donta C, Gavala S, Karayianni K, Kamenopoulou V, Hourdakis CJ. Dose reduction in maxillofacial imaging using low dose Cone Beam CT. Eur J Radiol 2005; 56: 413-17.

Vocabulário internacional de termos fundamentais e gerais de Metrologia: portaria INMETRO nº 029 de 1995 / INMETRO, SENAI - Departamento Nacional. 5 ed. Rio de Janeiro: Ed. SENAI; 2007.

Zanelato ACT. Estudo das angulações e inclinações dentárias em brasileiros, leucodermas com oclusão normal natural.[Mestrado] São Bernardo do Campo (SP):Universidade Metodista de São Paulo;2003. 
ANEXOS 

ANEXOS

\section{ANEXO 1}

Tabela A - Medidas de T1 para o canino superior direito.

\begin{tabular}{l|ccccc}
\hline & Coroa Anatômica & Coroa Clínica & Ponto EV & Inclinação & Angulação \\
& & & & & \\
\hline Andre Luis da Silva & 7,60 & 5,80 & 2,90 & $-0,70$ & 2,80 \\
Andressa Tavares & 9,50 & 7,70 & 3,90 & 1,00 & 13,00 \\
Elizabete Cinta Larga & 7,40 & 5,60 & 2,80 & $-5,70$ & 8,30 \\
Jaqueline Oliveira Paixão & 7,70 & 5,90 & 3,00 & $-7,60$ & 15,50 \\
Gerson Antônio Migliani & 11,40 & 9,60 & 4,80 & 6,60 & 12,70 \\
Rafael Bald & 8,90 & 7,10 & 3,60 & 3,30 & 15,60 \\
Vanessa Galan & 8,90 & 7,10 & 3,60 & 1,10 & 9,90 \\
Laura Campos e Silva & 8,50 & 6,70 & 3,40 & $-6,10$ & 0,90 \\
Rodrigo dos Santos Vergínio & 8,00 & 6,20 & 3,10 & 2,40 & 6,30 \\
Rafael Flores de Freitas & 9,00 & $\mathbf{7 , 2 0}$ & 3,60 & $\mathbf{1 , 2 0}$ & 3,50 \\
Média & $\mathbf{8 , 6 9}$ & $\mathbf{6 , 8 9}$ & $\mathbf{3 , 4 7}$ & $\mathbf{- 0 , 4 5}$ & $\mathbf{8 , 8 5}$ \\
Desvio Padrão & $\mathbf{1 , 1 7 9 9}$ & $\mathbf{1 , 1 7 9 9}$ & $\mathbf{0 , 5 9 0 8}$ & $\mathbf{4 , 5 9 2 1}$ & $\mathbf{5 , 3 5 5 8}$ \\
\hline
\end{tabular}

Tabela B - Medidas de T2 para o canino superior direito.

\begin{tabular}{l|ccccc}
\hline & Coroa Anatômica & Coroa Clínica & Ponto EV & Inclinação & Angulação \\
& & & & & \\
\hline Andre Luis da Silva & 7,40 & 5,60 & 2,80 & $-0,10$ & 2,80 \\
Andressa Tavares & 9,40 & 7,60 & 3,80 & 1,30 & 12,60 \\
Elizabete Cinta Larga & 7,10 & 5,30 & 2,70 & $-5,40$ & 7,10 \\
Jaqueline Oliveira Paixão & 7,70 & 5,90 & 3,00 & $-7,60$ & 14,70 \\
Gerson Antônio Migliani & 11,20 & 9,40 & 4,70 & 7,30 & 12,20 \\
Rafael Bald & 8,90 & 7,10 & 3,60 & 3,90 & 15,30 \\
Vanessa Galan & 9,10 & 7,30 & 3,00 & 2,10 & 9,30 \\
Laura Campos e Silva & 8,80 & 7,00 & 3,50 & $-6,80$ & 0,80 \\
Rodrigo dos Santos Vergínio & 10,20 & 8,40 & 4,20 & 2,20 & 6,00 \\
Rafael Flores de Freitas & 8,20 & 6,40 & 3,20 & 2,00 & 2,70 \\
Média & $\mathbf{8 , 8 0}$ & $\mathbf{7 , 0 0}$ & $\mathbf{3 , 4 5}$ & $\mathbf{- 0 , 1 1}$ & $\mathbf{8 , 3 5}$ \\
Desvio Padrão & $\mathbf{1 , 2 7 3 7}$ & $\mathbf{1 , 2 7 3 7}$ & $\mathbf{0 , 6 4 3 3}$ & $\mathbf{4 , 9 0 4 5}$ & $\mathbf{5 , 2 6 2 3}$ \\
\hline
\end{tabular}


Tabela C - Medidas de T1 para o incisivo lateral superior direito.

\begin{tabular}{|c|c|c|c|c|c|}
\hline & Coroa Anatômica & Coroa Clínica & Ponto EV & Inclinação & Angulação \\
\hline Andre Luis da Silva & 8,70 & 6,90 & 3,50 & 2,20 & 8,40 \\
\hline Andressa Tavares & ----- & ------ & ----- & ----- & ----- \\
\hline Elizabete Cinta Larga & 9,20 & 7,40 & 3,70 & $-1,70$ & 5,00 \\
\hline Jaqueline Oliveira Paixão & ----- & ------ & ------ & ------ & ----- \\
\hline Gerson Antônio Migliani & 8,20 & 6,40 & 3,20 & 3,10 & 1,20 \\
\hline Rafael Bald & 9,30 & 7,50 & 3,80 & 6,20 & 14,40 \\
\hline Vanessa Galan & ----- & ------ & ------ & ------ & ----- \\
\hline Laura Campos e Silva & ----- & ----- & ----- & ----- & ----- \\
\hline Rodrigo dos Santos Vergínio & ------ & ------ & ------ & ------ & ----- \\
\hline Rafael Flores de Freitas & 11,00 & 9,20 & 4,60 & 2,90 & 9,60 \\
\hline Média & 9,28 & 7,48 & 3,76 & 2,54 & 7,72 \\
\hline Desvio Padrão & 1,0569 & 1,0569 & 0,5225 & 2,8254 & 4,9631 \\
\hline
\end{tabular}

Tabela D - Medidas de T2 para o incisivo lateral superior direito.

\begin{tabular}{|c|c|c|c|c|c|}
\hline & Coroa Anatômica & Coroa Clínica & Ponto EV & Inclinação & Angulação \\
\hline Andre Luis da Silva & 8,60 & 6,80 & 3,40 & 2,20 & 8,10 \\
\hline Andressa Tavares & ------ & ------ & ------ & ------ & ------ \\
\hline Elizabete Cinta Larga & 9,50 & 7,70 & 3,90 & $-1,10$ & 4,00 \\
\hline Jaqueline Oliveira Paixão & ------ & ------ & ------ & ------ & ------ \\
\hline Gerson Antônio Migliani & 8,40 & 6,60 & 3,30 & 3,60 & 2,10 \\
\hline Rafael Bald & 9,20 & 7,40 & 3,70 & 6,50 & 14,70 \\
\hline Vanessa Galan & ------ & ----- & ----- & ----- & ----- \\
\hline Laura Campos e Silva & ------ & ------ & ------ & ------ & ------ \\
\hline Rodrigo dos Santos Vergínio & ------ & ----- & ----- & ----- & ----- \\
\hline Rafael Flores de Freitas & 10,40 & 8,60 & 4,30 & 3,90 & 9,10 \\
\hline Média & 9,22 & 7,42 & 3,72 & 3,02 & 7,60 \\
\hline Desvio Padrão & 0,7950 & 0,7950 & 0,4025 & 2,7779 & 4,9020 \\
\hline
\end{tabular}

----Dente ausente 
Tabela E - Medidas de T1 para o incisivo central superior direito.

\begin{tabular}{l|ccccc}
\hline & Coroa Anatômica & Coroa Clínica & Ponto EV & Inclinação & Angulação \\
& & & & & \\
\hline Andre Luis da Silva & 9,10 & 7,30 & 3,70 & $-7,20$ & $-0,20$ \\
Andressa Tavares & 8,60 & 6,80 & 3,40 & 3,10 & $-5,80$ \\
Elizabete Cinta Larga & 8,70 & 6,90 & 3,50 & $-0,70$ & 2,60 \\
Jaqueline Oliveira Paixão & 9,20 & 7,40 & 3,70 & 0,70 & 3,60 \\
Gerson Antônio Migliani & 11,10 & 9,30 & 4,70 & 5,40 & 2,30 \\
Rafael Bald & ----- & ----- & ----- & ---- & ---- \\
Vanessa Galan & 10,50 & 8,70 & 4,40 & 13,20 & 4,00 \\
Laura Campos e Silva & 10,80 & 9,00 & 4,50 & 6,80 & $-9,50$ \\
Rodrigo dos Santos Vergínio & 9,80 & 8,00 & 4,00 & 9,30 & 2,90 \\
Rafael Flores de Freitas & 9,60 & 7,80 & 3,60 & 5,20 & 6,60 \\
Média & $\mathbf{9 , 7 1}$ & $\mathbf{7 , 9 1}$ & $\mathbf{3 , 9 4}$ & $\mathbf{3 , 9 8}$ & $\mathbf{0 , 7 2}$ \\
Desvio Padrão & $\mathbf{0 , 9 1 1 7}$ & $\mathbf{0 , 9 1 1 7}$ & $\mathbf{0 , 4 7 7 3}$ & $\mathbf{5 , 9 4 9 7}$ & $\mathbf{5 , 1 5 0 4}$ \\
\hline
\end{tabular}

Tabela F - Medidas de T2 para o incisivo central superior direito.

\begin{tabular}{|c|c|c|c|c|c|}
\hline & Coroa Anatômica & Coroa Clínica & Ponto EV & Inclinação & Angulação \\
\hline Andre Luis da Silva & 9,00 & 7,20 & 3,60 & $-7,80$ & $-0,90$ \\
\hline Andressa Tavares & 9,10 & 7,30 & 3,20 & 3,60 & $-5,00$ \\
\hline Elizabete Cinta Larga & 8,00 & 6,20 & 3,10 & 0,00 & 2,60 \\
\hline Jaqueline Oliveira Paixão & 8,80 & 7,00 & 3,50 & 0,90 & 3,40 \\
\hline Gerson Antônio Migliani & 11,30 & 9,50 & 4,80 & 5,80 & 2,40 \\
\hline Rafael Bald & ------ & ----- & ------ & ------ & ----- \\
\hline Vanessa Galan & 10,20 & 8,40 & 4,20 & 12,10 & 5,20 \\
\hline Laura Campos e Silva & 10,70 & 8,90 & 4,50 & 6,30 & $-10,00$ \\
\hline Rodrigo dos Santos Vergínio & 10,20 & 8,40 & 4,20 & 8,40 & 2,70 \\
\hline Rafael Flores de Freitas & 8,90 & 7,10 & 3,60 & 5,60 & 7,00 \\
\hline Média & 9,58 & 7,78 & 3,86 & 3,88 & 0,82 \\
\hline Desvio Padrão & 1,0674 & 1,0674 & 0,5918 & 5,7111 & 5,3284 \\
\hline
\end{tabular}


Tabela G - Medidas de T1 para o incisivo central superior esquerdo.

\begin{tabular}{l|ccccc}
\hline & Coroa Anatômica & Coroa Clínica & Ponto EV & Inclinação & Angulação \\
& & & & & \\
\hline Andre Luis da Silva & 8,10 & 6,30 & 3,20 & $-6,30$ & 0,50 \\
Andressa Tavares & 9,70 & 7,90 & 4,00 & 14,30 & 8,60 \\
Elizabete Cinta Larga & 9,50 & 7,70 & 3,90 & 1,60 & 2,90 \\
Jaqueline Oliveira Paixão & 10,20 & 8,40 & 4,20 & $-4,90$ & $-3,50$ \\
Gerson Antônio Migliani & 10,20 & 8,40 & 4,20 & 4,10 & 0,20 \\
Rafael Bald & 10,50 & 8,70 & 4,40 & 7,20 & 7,40 \\
Vanessa Galan & 9,50 & 7,70 & 3,90 & 10,70 & $-3,20$ \\
Laura Campos e Silva & 9,60 & 7,80 & 3,90 & 1,60 & 9,90 \\
Rodrigo dos Santos Vergínio & 10,40 & 8,60 & 4,30 & 11,00 & 5,60 \\
Rafael Flores de Freitas & $\mathbf{7 , 4 0}$ & 5,60 & $\mathbf{2 , 8 0}$ & $-1,30$ & $-14,70$ \\
Média & $\mathbf{9 , 5 1}$ & $\mathbf{7 , 7 1}$ & $\mathbf{3 , 8 8}$ & $\mathbf{3 , 8 0}$ & $\mathbf{1 , 3 7}$ \\
Desvio Padrão & $\mathbf{1 , 0 1 1 5}$ & $\mathbf{1 , 0 1 1 5}$ & $\mathbf{0 , 5 0 5 1}$ & $\mathbf{6 , 9 5 0 1}$ & $\mathbf{7 , 3 5 3 0}$ \\
\hline
\end{tabular}

Tabela H - Medidas de T2 para o incisivo central superior esquerdo.

\begin{tabular}{l|ccccc}
\hline & Coroa Anatômica & Coroa Clínica & Ponto EV & Inclinação & Angulação \\
& & & & & \\
\hline Andre Luis da Silva & 7,90 & 6,10 & 3,10 & $-7,00$ & 0,50 \\
Andressa Tavares & 10,00 & 8,20 & 4,10 & 14,30 & 9,40 \\
Elizabete Cinta Larga & 10,30 & 8,50 & 4,30 & 1,40 & 1,70 \\
Jaqueline Oliveira Paixão & 10,50 & 8,70 & 4,40 & $-4,20$ & $-3,10$ \\
Gerson Antônio Migliani & 10,40 & 8,60 & 4,30 & 5,30 & 0,50 \\
Rafael Bald & 11,00 & 9,20 & 4,60 & 6,20 & 6,10 \\
Vanessa Galan & 9,70 & 7,90 & 4,00 & 10,10 & $-3,40$ \\
Laura Campos e Silva & 9,60 & 7,80 & 3,90 & 1,90 & 9,10 \\
Rodrigo dos Santos Vergínio & 10,00 & 8,20 & 4,00 & 11,80 & 6,10 \\
Rafael Flores de Freitas & 7,80 & 6,00 & 3,00 & $-1,10$ & $-15,40$ \\
Média & $\mathbf{9 , 7 2}$ & $\mathbf{7 , 9 2}$ & $\mathbf{3 , 9 7}$ & $\mathbf{3 , 8 7}$ & $\mathbf{1 , 1 5}$ \\
Desvio Padrão & $\mathbf{1 , 0 6 5 4}$ & $\mathbf{1 , 0 6 5 4}$ & $\mathbf{0 , 5 2 9 3}$ & $\mathbf{6 , 9 5 9 6}$ & $\mathbf{7 , 4 0 9 3}$ \\
\hline
\end{tabular}


Tabela I - Medidas de T1 para o incisivo lateral superior esquerdo.

\begin{tabular}{|c|c|c|c|c|c|}
\hline & Coroa Anatômica & Coroa Clínica & Ponto EV & Inclinação & Angulação \\
\hline Andre Luis da Silva & 9,10 & 7,30 & 3,70 & 4,00 & 8,40 \\
\hline Andressa Tavares & ----- & ----- & ----- & ----- & ----- \\
\hline Elizabete Cinta Larga & 8,10 & 6,30 & 3,20 & $-3,00$ & 4,50 \\
\hline Jaqueline Oliveira Paixão & ------ & ----- & ----- & ----- & ----- \\
\hline Gerson Antônio Migliani & 10,10 & 8,30 & 4,20 & 1,90 & 1,10 \\
\hline Rafael Bald & 10,00 & 8,20 & 4,10 & 5,50 & 24,00 \\
\hline Vanessa Galan & ------ & ------ & ------ & ----- & ------ \\
\hline Laura Campos e Silva & ----- & ----- & ----- & ----- & ----- \\
\hline Rodrigo dos Santos Vergínio & ----- & ------ & ----- & ----- & ----- \\
\hline Rafael Flores de Freitas & 10,50 & 8,70 & 4,40 & 1,40 & 8,50 \\
\hline Média & 9,56 & 7,76 & 3,92 & 1,96 & 9,30 \\
\hline Desvio Padrão & 0,9633 & 0,9633 & 0,4764 & 3,2254 & 8,7724 \\
\hline
\end{tabular}

---Dente ausente

Tabela J - Medidas de T2 para o incisivo lateral superior esquerdo.

\begin{tabular}{|c|c|c|c|c|c|}
\hline & Coroa Anatômica & Coroa Clínica & Ponto EV & Inclinação & Angulação \\
\hline Andre Luis da Silva & 9,30 & 7,50 & 3,80 & 4,20 & 9,60 \\
\hline Andressa Tavares & ------ & ------ & ------ & ----- & ------ \\
\hline Elizabete Cinta Larga & 8,50 & 6,70 & 3,40 & $-2,30$ & 3,00 \\
\hline Jaqueline Oliveira Paixão & ------ & ------ & ------ & ------ & ------ \\
\hline Gerson Antônio Migliani & 9,70 & 7,90 & 4,00 & 2,00 & 1,10 \\
\hline Rafael Bald & 10,40 & 8,60 & 4,30 & 4,50 & 23,40 \\
\hline Vanessa Galan & ----- & ------ & ------ & ------ & ------ \\
\hline Laura Campos e Silva & ------ & ------ & ------ & ----- & ------ \\
\hline Rodrigo dos Santos Vergínio & ------ & ------ & ------ & ----- & ------ \\
\hline Rafael Flores de Freitas & 10,40 & 8,60 & 4,30 & 2,90 & 7,50 \\
\hline Média & 9,66 & 7,86 & 3,96 & 2,26 & 8,92 \\
\hline Desvio Padrão & 0,8019 & 0,8019 & 0,3782 & 2,7410 & 8,7799 \\
\hline
\end{tabular}

---Dente ausente 
Tabela K - Medidas de T1 para o canino superior esquerdo.

\begin{tabular}{l|ccccc}
\hline & Coroa Anatômica & Coroa Clínica & Ponto EV & Inclinação & Angulação \\
& & & & & \\
\hline Andre Luis da Silva & 6,80 & 5,00 & 2,50 & 1,80 & 8,80 \\
Andressa Tavares & 8,90 & 7,10 & 3,60 & 1,00 & 13,70 \\
Elizabete Cinta Larga & 7,30 & 5,50 & 2,80 & $-6,20$ & 11,50 \\
Jaqueline Oliveira Paixão & 8,20 & 6,40 & 3,20 & $-4,60$ & 16,00 \\
Gerson Antônio Migliani & 10,70 & 8,90 & 4,50 & 7,00 & 15,50 \\
Rafael Bald & 8,00 & 6,20 & 3,10 & 5,10 & 16,90 \\
Vanessa Galan & 9,50 & 7,70 & 3,90 & $-8,10$ & 8,40 \\
Laura Campos e Silva & 9,70 & 7,90 & 4,00 & 1,80 & 16,60 \\
Rodrigo dos Santos Vergínio & ----- & ----- & ----- & ---- & ---- \\
Rafael Flores de Freitas & 8,20 & 6,40 & 3,20 & $-3,40$ & 5,00 \\
Média & $\mathbf{8 , 5 9}$ & $\mathbf{6 , 7 9}$ & $\mathbf{3 , 4 2}$ & $-\mathbf{0 , 6 2}$ & $\mathbf{1 2 , 4 9}$ \\
Desvio Padrão & $\mathbf{1 , 2 3 1 3}$ & $\mathbf{1 , 2 3 1 3}$ & $\mathbf{0 , 6 3 2 0}$ & $\mathbf{5 , 1 9 3 5}$ & $\mathbf{4 , 2 8 0 9}$ \\
\hline
\end{tabular}

---Dente ausente

Tabela L - Medidas de T2 para o canino superior esquerdo.

\begin{tabular}{l|ccccc}
\hline & Coroa Anatômica & Coroa Clínica & Ponto EV & Inclinação & Angulação \\
& & & & & \\
\hline Andre Luis da Silva & 6,50 & 4,70 & 2,90 & 2,90 & 7,00 \\
Andressa Tavares & 9,10 & 7,30 & 3,70 & 1,90 & 12,10 \\
Elizabete Cinta Larga & 7,60 & 5,80 & 2,90 & $-5,00$ & 10,50 \\
Jaqueline Oliveira Paixão & 8,50 & 6,70 & 3,40 & $-4,30$ & 16,00 \\
Gerson Antônio Migliani & 11,10 & 9,30 & 4,70 & 6,80 & 16,40 \\
Rafael Bald & 8,20 & 6,40 & 3,20 & 5,80 & 17,00 \\
Vanessa Galan & 9,20 & 7,40 & 3,70 & 2,40 & 8,40 \\
Laura Campos e Silva & 9,40 & 7,60 & 3,80 & $-8,00$ & 16,50 \\
Rodrigo dos Santos Vergínio & ----- & ----- & ----- & ----- & --- \\
Rafael Flores de Freitas & 8,30 & 6,50 & 3,30 & $-4,90$ & 5,30 \\
Média & $\mathbf{8 , 6 6}$ & $\mathbf{6 , 8 6}$ & $\mathbf{3 , 5 1}$ & $-\mathbf{0 , 2 7}$ & $\mathbf{1 2 , 1 3}$ \\
Desvio Padrão & $\mathbf{1 , 2 8 1 7}$ & $\mathbf{1 , 2 8 1 7}$ & $\mathbf{0 , 5 5 5 5}$ & $\mathbf{5 , 3 4 4 6}$ & $\mathbf{4 , 5 4 9 2}$ \\
\hline
\end{tabular}

---Dente ausente 
Tabela M - Medidas de T1 para o canino inferior esquerdo.

\begin{tabular}{l|ccccc}
\hline & Coroa Anatômica & Coroa Clínica & Ponto EV & Inclinação & Angulação \\
& & & & & \\
\hline Andre Luis da Silva & 10,5 & 8,7 & 4,4 & $-9,8$ & 5,4 \\
Andressa Tavares & 10,2 & 8,4 & 4,2 & $-3,8$ & 9,3 \\
Elizabete Cinta Larga & 10,3 & 8,5 & 4,3 & 2,7 & 8,9 \\
Jaqueline Oliveira Paixão & 8,2 & 6,4 & 3,2 & $-3,9$ & 2,6 \\
Gerson Antônio Migliani & 11,3 & 9,5 & 4,8 & $-3,1$ & 11,5 \\
Rafael Bald & 11,8 & 10,0 & 5,0 & $-8,8$ & 6,8 \\
Vanessa Galan & 9,1 & 7,3 & 3,7 & $-7,4$ & 6,3 \\
Laura Campos e Silva & 9,7 & 7,9 & 4,0 & $-13,3$ & 8,0 \\
Rodrigo dos Santos Vergínio & 12,3 & 10,5 & 5,3 & $-3,0$ & 4,8 \\
Rafael Flores de Freitas & 10,7 & 8,9 & 4,5 & $-3,1$ & 8,1 \\
Média & $\mathbf{1 0 , 4 1}$ & $\mathbf{8 , 6 1}$ & $\mathbf{4 , 3 4}$ & $\mathbf{- 5 , 3 5}$ & $\mathbf{7 , 1 7}$ \\
Desvio Padrão & $\mathbf{1 , 2 2 7 0}$ & $\mathbf{1 , 2 2 7 0}$ & $\mathbf{0 , 6 1 8 6}$ & $\mathbf{4 , 5 2 2 4}$ & $\mathbf{2 , 5 4 6 5}$ \\
\hline
\end{tabular}

Tabela N - Medidas de T2 para o canino inferior esquerdo.

\begin{tabular}{l|ccccc}
\hline & Coroa Anatômica & Coroa Clínica & Ponto EV & Inclinação & Angulação \\
& & & & & \\
\hline Andre Luis da Silva & 10,7 & 8,9 & 4,5 & $-10,9$ & 6,3 \\
Andressa Tavares & 10,4 & 8,6 & 4,3 & $-3,5$ & 8,3 \\
Elizabete Cinta Larga & 10,3 & 8,5 & 4,3 & 1,7 & 8,4 \\
Jaqueline Oliveira Paixão & 8,0 & 6,2 & 3,1 & $-3,2$ & 2,9 \\
Gerson Antônio Migliani & 11,1 & 9,3 & 4,7 & $-3,8$ & 10,6 \\
Rafael Bald & 11,3 & 9,5 & 4,8 & $-7,5$ & 6,4 \\
Vanessa Galan & 10,1 & 8,3 & 4,2 & $-7,2$ & 6,2 \\
Laura Campos e Silva & 9,6 & 7,8 & 3,9 & $-11,9$ & 9,3 \\
Rodrigo dos Santos Vergínio & 12,5 & 10,7 & 5,4 & $-2,6$ & 4,7 \\
Rafael Flores de Freitas & 10,8 & 9,0 & 4,5 & $-2,7$ & 8,8 \\
Média & $\mathbf{1 0 , 4 8}$ & $\mathbf{8 , 6 8}$ & 4,37 & $-\mathbf{5 , 1 6}$ & $\mathbf{7 , 1 9}$ \\
Desvio Padrão & $\mathbf{1 , 1 7 3 6}$ & $\mathbf{1 , 1 7 3 6}$ & 0,6019 & $\mathbf{4 , 1 6 5 0}$ & $\mathbf{2 , 3 1 8 3}$ \\
\hline
\end{tabular}


Tabela $\mathbf{O}$ - Medidas de T1 para o incisivo lateral inferior esquerdo.

\begin{tabular}{l|ccccc}
\hline & Coroa Anatômica & Coroa Clínica & Ponto EV & Inclinação & Angulação \\
& & & & & \\
\hline Andre Luis da Silva & 8,60 & 6,80 & 3,40 & $-11,90$ & 3,70 \\
Andressa Tavares & 8,00 & 6,20 & 3,10 & $-2,20$ & 3,30 \\
Elizabete Cinta Larga & 8,30 & 6,50 & 3,30 & 12,00 & 4,50 \\
Jaqueline Oliveira Paixão & 9,10 & 7,30 & 3,70 & 2,50 & 0,50 \\
Gerson Antônio Migliani & 10,20 & 8,40 & 4,20 & 4,60 & 12,40 \\
Rafael Bald & 9,20 & 7,40 & 3,70 & $-4,60$ & $-2,60$ \\
Vanessa Galan & 8,50 & 6,70 & 3,40 & $-2,70$ & 2,70 \\
Laura Campos e Silva & 9,70 & 7,90 & 4,00 & $-3,70$ & 3,90 \\
Rodrigo dos Santos Vergínio & 9,80 & 8,00 & 4,40 & 3,00 & 4,20 \\
Rafael Flores de Freitas & 8,20 & 6,40 & 3,20 & $-2,50$ & 7,40 \\
Média & $\mathbf{8 , 9 6}$ & $\mathbf{7 , 1 6}$ & $\mathbf{3 , 6 4}$ & $-\mathbf{0 , 5 5}$ & $\mathbf{4 , 0 0}$ \\
Desvio Padrão & $\mathbf{0 , 7 5 6 0}$ & $\mathbf{0 , 7 5 6 0}$ & $\mathbf{0 , 4 4 0 2}$ & $\mathbf{6 , 4 3 1 0}$ & $\mathbf{3 , 9 5 1 1}$ \\
\hline
\end{tabular}

Tabela P - Medidas de T2 para o incisivo lateral inferior esquerdo.

\begin{tabular}{l|ccccc}
\hline & Coroa Anatômica & Coroa Clínica & Ponto EV & Inclinação & Angulação \\
& & & & & \\
\hline Andre Luis da Silva & 8,30 & 6,50 & 3,30 & $-12,90$ & 3,90 \\
Andressa Tavares & 8,10 & 6,30 & 3,20 & $-2,60$ & 3,90 \\
Elizabete Cinta Larga & 8,10 & 6,30 & 3,20 & 11,90 & 3,50 \\
Jaqueline Oliveira Paixão & 8,80 & 7,00 & 3,50 & 1,60 & 0,50 \\
Gerson Antônio Migliani & 10,40 & 8,60 & 4,30 & 4,50 & 12,40 \\
Rafael Bald & 9,60 & 7,80 & 3,90 & $-5,00$ & $-2,60$ \\
Vanessa Galan & 9,60 & 7,80 & 3,90 & $-2,10$ & 2,70 \\
Laura Campos e Silva & 9,20 & 7,40 & 3,70 & $-3,60$ & 3,90 \\
Rodrigo dos Santos Vergínio & 10,90 & 9,10 & 4,60 & 3,50 & 3,90 \\
Rafael Flores de Freitas & 8,90 & 7,10 & 3,60 & $-1,20$ & 7,20 \\
Média & $\mathbf{9 , 1 9}$ & $\mathbf{7 , 3 9}$ & $\mathbf{3 , 7 2}$ & $\mathbf{- 0 , 5 9}$ & $\mathbf{3 , 9 3}$ \\
Desvio Padrão & $\mathbf{0 , 9 5 0 4}$ & $\mathbf{0 , 9 5 0 4}$ & $\mathbf{0 , 4 6 6 2}$ & $\mathbf{6 , 5 8 4 2}$ & $\mathbf{3 , 9 2 3 4}$ \\
\hline
\end{tabular}


Tabela Q - Medidas de T1 para o incisivo central inferior esquerdo.

\begin{tabular}{l|ccccc}
\hline & Coroa Anatômica & Coroa Clínica & Ponto EV & Inclinação & Angulação \\
& & & & & \\
\hline Andre Luis da Silva & 7,90 & 6,10 & 3,10 & $-6,70$ & 3,20 \\
Andressa Tavares & 7,00 & 5,20 & 2,60 & $-3,60$ & 3,30 \\
Elizabete Cinta Larga & 8,00 & 6,20 & 3,10 & 12,30 & $-4,80$ \\
Jaqueline Oliveira Paixão & 8,40 & 6,60 & 3,30 & 2,00 & 4,40 \\
Gerson Antônio Migliani & 8,80 & 7,00 & 3,50 & 9,00 & 5,10 \\
Rafael Bald & 9,40 & 7,60 & 3,80 & $-2,40$ & $-3,50$ \\
Vanessa Galan & 9,20 & 7,40 & 3,70 & $-1,40$ & 0,80 \\
Laura Campos e Silva & 9,40 & 7,60 & 3,80 & $-1,90$ & 0,00 \\
Rodrigo dos Santos Vergínio & 10,00 & 8,20 & 4,10 & 3,30 & 3,80 \\
Rafael Flores de Freitas & 7,70 & 5,90 & 3,00 & $-2,00$ & 2,50 \\
Média & $\mathbf{8 , 5 8}$ & $\mathbf{6 , 7 8}$ & $\mathbf{3 , 4 0}$ & $\mathbf{0 , 8 6}$ & $\mathbf{1 , 4 8}$ \\
Desvio Padrão & $\mathbf{0 , 9 3 6 7}$ & $\mathbf{0 , 9 3 6 7}$ & $\mathbf{0 , 4 5 9 5}$ & $\mathbf{5 , 8 9 6 9}$ & $\mathbf{3 , 3 5 3 5}$ \\
\hline
\end{tabular}

Tabela R - Medidas de T2 para o incisivo central inferior esquerdo.

\begin{tabular}{l|ccccc}
\hline & Coroa Anatômica & Coroa Clínica & Ponto EV & Inclinação & Angulação \\
& & & & & \\
\hline Andre Luis da Silva & 7,90 & 6,10 & 3,10 & $-7,10$ & 3,20 \\
Andressa Tavares & 7,50 & 5,70 & 2,90 & $-2,50$ & 3,20 \\
Elizabete Cinta Larga & 8,20 & 6,40 & 3,20 & 11,60 & $-4,50$ \\
Jaqueline Oliveira Paixão & 8,70 & 6,90 & 3,50 & 2,30 & 4,60 \\
Gerson Antônio Migliani & 8,70 & 6,90 & 3,50 & 9,10 & 5,50 \\
Rafael Bald & 9,40 & 7,60 & 3,80 & $-1,70$ & $-2,80$ \\
Vanessa Galan & 9,30 & 7,50 & 3,80 & $-1,70$ & 0,30 \\
Laura Campos e Silva & 9,30 & 7,50 & 3,80 & $-2,60$ & 0,20 \\
Rodrigo dos Santos Vergínio & 10,20 & 8,40 & 4,20 & 4,00 & 4,00 \\
Rafael Flores de Freitas & 8,80 & $\mathbf{7 , 0 0}$ & $\mathbf{3 , 5 0}$ & $-1,40$ & $\mathbf{2 , 8 0}$ \\
Média & $\mathbf{8 , 8 0}$ & $\mathbf{7 , 0 0}$ & $\mathbf{3 , 5 3}$ & $\mathbf{1 , 0 0}$ & $\mathbf{1 , 6 5}$ \\
Desvio Padrão & $\mathbf{0 , 7 9 5 8}$ & $\mathbf{0 , 7 9 5 8}$ & $\mathbf{0 , 3 8 8 9}$ & $\mathbf{5 , 7 7 1 8}$ & $\mathbf{3 , 2 7 8 3}$ \\
\hline
\end{tabular}


Tabela S - Medidas de T1 para o incisivo central inferior direito.

\begin{tabular}{|c|c|c|c|c|c|}
\hline & Coroa Anatômica & Coroa Clínica & Ponto EV & Inclinação & Angulação \\
\hline Andre Luis da Silva & 8,40 & 6,60 & 3,30 & $-5,3$ & $-4,20$ \\
\hline Andressa Tavares & 8,30 & 6,50 & 3,30 & $-3,1$ & $-1,40$ \\
\hline Elizabete Cinta Larga & 8,00 & 6,20 & 3,10 & 12,5 & 4,10 \\
\hline Jaqueline Oliveira Paixão & 8,40 & 6,60 & 3,30 & $-1,5$ & $-1,20$ \\
\hline Gerson Antônio Migliani & 9,30 & 7,50 & 3,80 & 9,3 & 7,90 \\
\hline Rafael Bald & 9,60 & 7,80 & 3,90 & $-1,7$ & 3,30 \\
\hline Vanessa Galan & 8,50 & 6,70 & 3,40 & $-1,4$ & 0,30 \\
\hline Laura Campos e Silva & 9,00 & 7,20 & 3,60 & $-2,6$ & $-0,90$ \\
\hline Rodrigo dos Santos Vergínio & 9,50 & 7,70 & 3,90 & 3,0 & 3,60 \\
\hline Rafael Flores de Freitas & ------ & ----- & ------ & & ----- \\
\hline Média & 8,78 & 6,98 & 3,51 & 1,02 & 1,28 \\
\hline Desvio Padrão & 0,5826 & 0,5826 & 0,2977 & 6,0611 & 3,7134 \\
\hline
\end{tabular}

----Dente ausente

Tabela T - Medidas de T2 para o incisivo central inferior direito.

\begin{tabular}{l|ccccc}
\hline & Coroa Anatômica & Coroa Clínica & Ponto EV & Inclinação & Angulação \\
& & & & & \\
\hline Andre Luis da Silva & 8,00 & 6,20 & 3,10 & $-4,00$ & $-4,00$ \\
Andressa Tavares & 8,20 & 6,40 & 3,20 & $-3,70$ & $-0,50$ \\
Elizabete Cinta Larga & 8,30 & 6,50 & 3,30 & 13,00 & 4,00 \\
Jaqueline Oliveira Paixão & 8,50 & 6,70 & 3,40 & $-1,50$ & $-1,90$ \\
Gerson Antônio Migliani & 9,70 & 7,90 & 4,00 & 9,50 & 8,40 \\
Rafael Bald & 9,90 & 8,10 & 4,10 & $-1,10$ & 3,20 \\
Vanessa Galan & 9,00 & 7,20 & 3,60 & $-1,70$ & 0,30 \\
Laura Campos e Silva & 9,00 & 7,20 & 3,60 & $-2,30$ & $-0,20$ \\
Rodrigo dos Santos Vergínio & 9,90 & 8,10 & 4,10 & 3,70 & 3,40 \\
Rafael Flores de Freitas & ----- & ----- & ----- & & ---- \\
Média & $\mathbf{8 , 9 4}$ & $\mathbf{7 , 1 4}$ & $\mathbf{3 , 6 0}$ & $\mathbf{1 , 3 2}$ & $\mathbf{1 , 4 1}$ \\
Desvio Padrão & $\mathbf{0 , 7 4 6 8}$ & $\mathbf{0 , 7 4 6 8}$ & $\mathbf{0 , 3 8 7 3}$ & $\mathbf{6 , 1 0 8 8}$ & $\mathbf{3 , 7 1 5 3}$ \\
\hline
\end{tabular}

----Dente ausente 
Tabela U - Medidas de T1 para o incisivo lateral inferior direito.

\begin{tabular}{l|ccccc}
\hline & Coroa Anatômica & Coroa Clínica & Ponto EV & Inclinação & Angulação \\
& & & & & \\
\hline Andre Luis da Silva & 9,00 & 7,20 & 3,60 & $-5,20$ & $-2,00$ \\
Andressa Tavares & 8,20 & 6,40 & 3,20 & $-2,90$ & 2,00 \\
Elizabete Cinta Larga & 7,80 & 6,00 & 3,00 & 12,80 & 3,70 \\
Jaqueline Oliveira Paixão & 8,50 & 6,70 & 3,40 & 0,80 & 0,70 \\
Gerson Antônio Migliani & 9,60 & 7,80 & 3,90 & 4,40 & 7,70 \\
Rafael Bald & 9,70 & 7,90 & 4,00 & $-7,40$ & $-1,50$ \\
Vanessa Galan & 9,40 & 7,60 & 3,80 & $-1,90$ & 3,70 \\
Laura Campos e Silva & 9,60 & 7,80 & 3,90 & $-7,10$ & $-1,10$ \\
Rodrigo dos Santos Vergínio & 9,00 & 7,20 & 3,60 & 0,80 & 5,50 \\
Rafael Flores de Freitas & 8,50 & 6,70 & 3,40 & $-1,80$ & 4,70 \\
Média & $\mathbf{8 , 9 3}$ & $\mathbf{7 , 1 3}$ & $\mathbf{3 , 5 8}$ & $\mathbf{- 0 , 7 5}$ & $\mathbf{2 , 3 4}$ \\
Desvio Padrão & $\mathbf{0 , 6 5 8 4}$ & $\mathbf{0 , 6 5 8 4}$ & $\mathbf{0 , 3 2 9 3}$ & $\mathbf{6 , 0 2 1 5}$ & $\mathbf{3 , 2 6 9 5}$ \\
\hline
\end{tabular}

Tabela V - Medidas de T2 para o incisivo lateral inferior direito.

\begin{tabular}{l|ccccc}
\hline & Coroa Anatômica & Coroa Clínica & Ponto EV & Inclinação & Angulação \\
& & & & & \\
\hline Andre Luis da Silva & 8,80 & 7,00 & 3,50 & $-4,40$ & $-2,00$ \\
Andressa Tavares & 8,40 & 6,60 & 3,30 & $-2,70$ & 2,80 \\
Elizabete Cinta Larga & 8,00 & 6,20 & 3,10 & 12,60 & 3,10 \\
Jaqueline Oliveira Paixão & 7,90 & 6,10 & 3,10 & 0,50 & 0,70 \\
Gerson Antônio Migliani & 10,00 & 8,20 & 4,00 & 4,30 & 7,70 \\
Rafael Bald & 9,90 & 8,10 & 4,10 & $-6,70$ & $-1,30$ \\
Vanessa Galan & 9,10 & 7,30 & 3,00 & $-3,10$ & 2,80 \\
Laura Campos e Silva & 9,20 & 7,40 & 3,70 & $-6,00$ & $-1,30$ \\
Rodrigo dos Santos Vergínio & 10,30 & 8,50 & 4,30 & 1,50 & 5,00 \\
Rafael Flores de Freitas & 8,60 & 6,80 & 3,40 & $-1,00$ & 4,80 \\
Média & $\mathbf{9 , 0 2}$ & $\mathbf{7 , 2 2}$ & $\mathbf{3 , 5 5}$ & $-\mathbf{0 , 5 0}$ & $\mathbf{2 , 2 3}$ \\
Desvio Padrão & $\mathbf{0 , 8 3 7 7}$ & $\mathbf{0 , 8 3 7 7}$ & $\mathbf{0 , 4 5 7 7}$ & $\mathbf{5 , 7 2 9 1}$ & $\mathbf{3 , 1 7 5 6}$ \\
\hline
\end{tabular}


Tabela X - Medidas de T1 para o canino inferior direito.

\begin{tabular}{l|ccccc}
\hline & Coroa Anatômica & Coroa Clínica & Ponto EV & Inclinação & Angulação \\
& & & & & \\
\hline Andre Luis da Silva & 10,50 & 8,70 & 4,40 & $-8,00$ & 0,20 \\
Andressa Tavares & 11,10 & 9,30 & 4,70 & $-2,30$ & 8,20 \\
Elizabete Cinta Larga & 9,40 & 7,60 & 3,80 & 3,20 & 8,10 \\
Jaqueline Oliveira Paixão & 8,80 & 7,00 & 3,50 & $-4,80$ & 1,30 \\
Gerson Antônio Migliani & 10,80 & 9,00 & 4,50 & $-4,10$ & 9,90 \\
Rafael Bald & 9,90 & 8,10 & 4,10 & $-8,70$ & 5,30 \\
Vanessa Galan & 9,50 & 7,70 & 3,90 & $-8,00$ & 6,70 \\
Laura Campos e Silva & 10,10 & 8,30 & 4,20 & $-13,80$ & 4,50 \\
Rodrigo dos Santos Vergínio & 11,20 & 9,40 & 4,70 & $-4,00$ & 5,40 \\
Rafael Flores de Freitas & 10,90 & 9,10 & 4,60 & $-3,10$ & 5,80 \\
Média & $\mathbf{1 0 , 2 2}$ & $\mathbf{8 , 4 2}$ & $\mathbf{4 , 2 4}$ & $\mathbf{- 5 , 3 6}$ & $\mathbf{5 , 5 4}$ \\
Desvio Padrão & $\mathbf{0 , 8 1 2 1}$ & $\mathbf{0 , 8 1 2 1}$ & $\mathbf{0 , 4 1 1 5}$ & $\mathbf{4 , 5 6 8 3}$ & $\mathbf{3 , 0 1 3 0}$ \\
\hline
\end{tabular}

Tabela $\mathbf{Z}$ - Medidas de T2 para o canino inferior direito.

\begin{tabular}{l|ccccc}
\hline & Coroa Anatômica & Coroa Clínica & Ponto EV & Inclinação & Angulação \\
& & & & & \\
\hline Andre Luis da Silva & 10,30 & 8,50 & 4,30 & $-8,50$ & 0,80 \\
Andressa Tavares & 10,60 & 8,80 & 4,40 & $-2,10$ & 8,70 \\
Elizabete Cinta Larga & 9,50 & 7,70 & 3,90 & 2,50 & 7,40 \\
Jaqueline Oliveira Paixão & 8,90 & 7,10 & 3,60 & $-5,90$ & 1,10 \\
Gerson Antônio Migliani & 10,40 & 8,60 & 4,80 & $-3,90$ & 10,10 \\
Rafael Bald & 11,10 & 9,30 & 4,70 & $-8,20$ & 5,60 \\
Vanessa Galan & 10,10 & 8,30 & 4,20 & $-8,00$ & 6,70 \\
Laura Campos e Silva & 10,40 & 8,60 & 4,30 & $-12,70$ & 3,40 \\
Rodrigo dos Santos Vergínio & 12,50 & 10,70 & 5,40 & $-4,50$ & 5,50 \\
Rafael Flores de Freitas & 11,40 & 9,60 & 4,80 & $-3,40$ & 5,50 \\
Média & $\mathbf{1 0 , 5 2}$ & $\mathbf{8 , 7 2}$ & $\mathbf{4 , 4 4}$ & $-\mathbf{5 , 4 7}$ & $\mathbf{5 , 4 8}$ \\
Desvio Padrão & $\mathbf{0 , 9 9 7 6}$ & $\mathbf{0 , 9 9 7 6}$ & $\mathbf{0 , 5 1 0 3}$ & $\mathbf{4 , 1 9 0 7}$ & $\mathbf{3 , 0 2 4 3}$ \\
\hline
\end{tabular}


Anexo 2 - Ofício de Aprovação do Comitê de Ética em Pesquisa
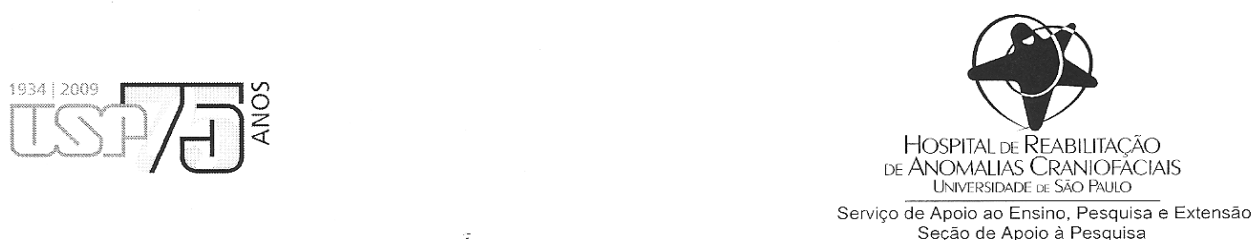

Ofício $n^{\circ}$ 086/2009-SVAPEPE-CEP

Bauru, 14 de maio de 2009.

Prezado(a) Senhor(a)

O projeto de pesquisa intitulado "Tomografia computadorizada: inclinação e angulação dos dentes anteriores em pacientes com fissura labiopalatina bilateral.", de autoria de FERNANDA PÁTARO MARSOLA RAZERA desenvolvido sob sua orientação, foi aprovado pelo CEP em 18 de dezembro de 2007.

Na reunião realizada em 28 de abril de 2009, as alterações solicitadas foram aprovadas, conforme parecer em anexo.

Informamos que após o recebimento do trabalho concluído, este Comitê enviará o parecer final que poderá ser utilizado para publicação.

Atenciosamente,

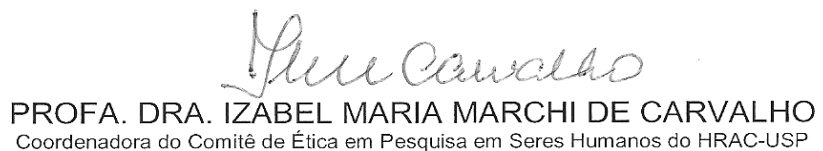

IImo(a) Sr(a)

Prof. Dr. Leopoldino Capelozza Filho

Ortodontia - HRAC/USP 